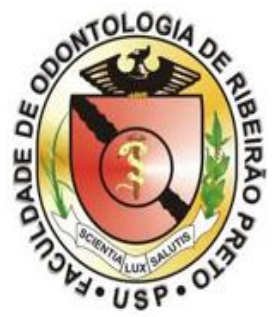

MAURICIO MARTINS PROVINCIATTI

ANÁLISE FOTOELÁSTICA COMPARATIVA ENTRE PILARES PROTÉTICOS SÓLIDOS E DE PARAFUSO PASSANTE PARA IMPLANTES COM CONEXÃO CÔNICA INSTALADOS EM DIFERENTES PROFUNDIDADES ÓSSEAS

Ribeirão Preto 


\section{ANÁLISE FOTOELÁSTICA COMPARATIVA ENTRE PILARES PROTÉTICOS SÓLIDOS E DE PARAFUSO PASSANTE PARA IMPLANTES COM CONEXÃO CÔNICA INSTALADOS EM DIFERENTES PROFUNDIDADES ÓSSEAS}

Dissertação apresentada ao Programa de PósGraduação em Reabilitação Oral da Faculdade de Odontologia de Ribeirão Preto da Universidade de São Paulo para obtenção do título de Mestre em Odontologia.

Orientador: Prof. Dr. Valdir Antonio Muglia

\section{VERSÃO CORRIGIDA}


Autorizo a reprodução e divulgação do teor total ou parcial deste trabalho, por qualquer meio convencional ou eletrônico, para fins de estudo e pesquisa, desde que citada a fonte.

Versão corrigida da Dissertação. A versão original se encontra disponível na Faculdade de Odontologia de Ribeirão Preto da Universidade de São Paulo

\section{FICHA CATALOGRÁFICA}

Provinciatti, Mauricio Martins

Análise Fotoelástica comparativa entre pilares protéticos sólidos e de parafuso passante para implantes com conexão cônica instalados em diferentes profundidades ósseas. Ribeirão Preto, 2015.

105 p.:il; $30 \mathrm{~cm}$.

Dissertação de Mestrado apresentada ao Programa de Pós-Graduação em Reabilitação Oral da Faculdade de Odontologia de Ribeirão Preto da Universidade de São Paulo - Departamento de Materiais Dentários e Prótese - para obtenção do título de Mestre em Odontologia. Área de concentração: Reabilitação Oral.

Orientador: Prof. Dr. Valdir Antonio Muglia.

1. Implantes dentais 2. Prótese sobre implante 3. Análise fotoelástica 4. Pilares protéticos 5. Conexão cônica. 
PROVINCIATTI, M.M. ANÁLISE FOTOELÁSTICA COMPARATIVA ENTRE PILARES PROTÉTICOS SÓLIDOS E DE PARAFUSO PASSANTE PARA IMPLANTES COM CONEXÃO CÔNICA INSTALADOS EM DIFERENTES PROFUNDIDADES ÓSSEAS

Dissertação apresentada ao Programa de PósGraduação em Reabilitação Oral da Faculdade de Odontologia de Ribeirão Preto da Universidade de São Paulo para obtenção do título de Mestre em Odontologia.

\section{BANCA EXAMINADORA}

1) Prof.(a). Dr.(a).:

Instituição:

Julgamento: Assinatura:

2) Prof.(a). Dr.(a).:

Instituição:

Julgamento: Assinatura:

3) Prof.(a). Dr.(a).:

Instituição:

Julgamento:

Assinatura:

A Comissão Julgadora dos trabalhos de defesa da Dissertação, como parte dos requisitos para obtenção do titulo de Mestre, em sessão pública realizada na cidade de Ribeirão Preto, em considerou o candidato: 
Dedicatória 
Aos meus pais, Maria e Osvaldo.

Mãe, me faltam palavras para expressar a gratidão que sinto.

Obrigado pelos conselhos, pelo ombro amigo para compartilhar as tristezas

e incertezas da vida e pelos abraços como demonstração de carinho e

felicidade por minhas conquistas.

Pai, vejo em sua figura o significado mais claro da palavra responsabilidade.

Nem sempre pudemos compartilhar momentos juntos. Porém, saiba que

onde vou o levo em meus pensamentos.

Aos meus irmãos, Marcele e Rafael.

Vocês determinaram muito do que sou, busquei em suas atitudes respostas que pudessem guiar minhas escolhas. Chegar até aqui é a prova de que as referências que tive foram simplesmente as melhores.

Dedico esta obra. 
A Faculdade de Odontologia de Ribeirão Preto da Universidade de São Paulo, por me acolher durante a graduação e pós-graduação e por oferecer toda a infraestrutura necessária para a execução da pesquisa;

Ao Prof. Dr. Valdir Antonio Muglia, pelo empenho como orientador, por não medir esforços em busca do sucesso da pesquisa e por compartilhar junto a mim seus mais amplos conhecimentos;

À Engenheira Ana Paula Macedo, pelo inesgotável auxîlio ao longo da pesquisa, estando presente inclusive nos momentos de maior dificuldade, pronta a dizer palavras de incentivo e conforto;

Deixo registrado minha eterna gratidão à instituição e às pessoas anteriormente citadas. 
AgRADECIMENTOS 
Ao Prof. Dr. Ricardo Faria Ribeiro, por gentilmente disponibilizar as instalações e os equipamentos utilizados no transcorrer da pesquisa;

À Profa. Dra. Maria da Glória Chiarello de Mattos, por prontamente colaborar com a pesquisa quando solicitada;

À Profa. Dra. Rossana Pereira de Almeida Antunes, pela compreensão e generosidade enquanto orientadora no Programa de Aperfeiçoamento de Ensino (PAE);

À Profa. Dra. Valéria Oliveira Pagnano de Souza e ao Prof. Dr. Wilson Matsumoto, por estarem dispostos à ajudar em qualquer ocasião;

Aos técnicos, Marcelo Aparecido Vieira, Lício Firmino Junior, José de Godoy Filho, José Henrique Loureiro, Eduardo Destito, Julio César Souza da Matta, Paulo César Teodoro, Paulo Sérgio Ferreira, Fernando Schiavetto e Luiz Sérgio Soares, pela atenção e amizade;

Às secretárias Fernanda Talita de Freitas, Regiane de Cássia Tirado Damasceno e Ana Paula Xavier, pela tolerância e disposição;

À Cirurgiã-Dentista Adriana C. Lapria Faria Queiroz, por demonstrar-se solícita durante a pesquisa;

Ao Prof. Dr. Jorge Jacob Liporaci Junior, pelos ensinamentos ofertados, mas sobretudo por acreditar em minha capacidade enquanto docente;

Aos alunos de mestrado e doutorado do Departamento de Materiais Dentários e Prótese da Faculdade de Odontologia de Ribeirão Preto da Universidade de São Paulo, por compartilharem seus anseios e saberes, tornando meu aprendizado mais enriquecedor;

À Coordenação de Aperfeiçoamento de Pessoal de Nivel Superior (CAPES), pela bolsa de estudos cedida; 
À empresa Dentsply Implants (Alemanha), por colaborar com a pesquisa disponibilizando informações de extrema valia;

Ao laboratório de próteses dentárias Domingos F. Facioli, por aceitar a demanda da pesquisa;

Deixo registrado meu sincero agradecimento às empresas e às pessoas anteriormente citadas. 
Resumo 
Provinciatti, M.M. ANÁLISE FOTOELÁSTICA COMPARATIVA ENTRE PILARES PROTÉTICOS SÓLIDOS E DE PARAFUSO PASSANTE PARA IMPLANTES COM CONEXÃO CÔNICA INSTALADOS EM DIFERENTES PROFUNDIDADES ÓSSEAS. 2015. 105f. Dissertação (Mestrado em Reabilitação Oral) - Faculdade de Odontologia de Ribeirão Preto, Universidade de São Paulo, Ribeirão Preto, 2015.

As tensões de baixa intensidade contribuem para a remodelação óssea nos implantes osseointegráveis, enquanto as tensões de alta intensidade causam a reabsorção óssea abaixo da interface implante-pilar. A sobrecarga oclusal afeta a fisiologia do tecido ósseo, rompendo com o equilíbrio entre a neoformação e a reabsorção. Como consequência da desarmonia, lacunas surgem em meio a superfície óssea, criando um ambiente favorável à proliferação de patógenos e ao acúmulo de fibras. Com a continuidade da sobrecarga e com a permanência dos microrganismos o suporte ósseo é comprometido, resultando na falha do implante. Em condições normais de carregamento, os implantes com conexão cônica possibilitam uma distribuição homogênea das tensões. $O$ posicionamento da plataforma protética abaixo da crista óssea determina a transferência das tensões para áreas distantes ao osso cortical. $O$ presente estudo utilizou a análise fotoelástica para avaliar a distribuição de tensão em modelos experimentais com implantes com conexão cônica instalados na posição equicristal, 1,5 mm infraósseo e 3,0 mm infraósseo. Foram propostas reabilitações com coroas protéticas unitárias em cerâmica, cimentadas em pilares protéticos sólidos e de parafuso passante com alturas de transmucoso de $1,5 \mathrm{~mm}, 3,0 \mathrm{~mm}$ e $4,5 \mathrm{~mm}$. Os implantes foram posicionados na posição correspondente ao primeiro molar inferior direito. Segundo as situações adotadas, os conjuntos implante/pilar foram avaliados isoladamente, adjacentes a réplicas do segundo pré-molar inferior direito e do segundo molar inferior direito e apenas adjacentes a réplicas do segundo pré-molar inferior direito. A carga aplicada aos modelos fotoelásticos foi de $200 \mathrm{Ncm}$ para todas as situações. Nos modelos com réplicas dentais foi realizado o carregamento oclusal distribuído, nos modelos com implantes isolados o carregamento foi pontual na fossa central e distal das coroas protéticas. Os resultados obtidos revelaram que a indicação de um pilar protético em detrimento a outro se configurou segundo a presença ou não de elemento dental posterior à coroa protética, assim como também por intermédio da profundidade da plataforma do implante na crista óssea remanescente. Em extremidades livres com implantes infraósseo a distribuição de tensão proporcionada pelo pilar de parafuso passante foi superior a do pilar sólido. Com a presença do segundo molar a distribuição da tensão foi mais eficiente com o pilar sólido, independentemente da profundidade da plataforma do implante. Nos modelos fotoelásticos com extremidade livre, o deslocamento da plataforma para uma posição infraóssea determinou menores tensões ao tecido ósseo. Havendo contatos proximais bilaterais a distribuição da tensão foi favorecida quando o implante ocupou a posição infraóssea a 3,0 mm, estando conectado ao pilar de parafuso passante. Entretanto, quando conectado ao pilar sólido o implante equicristal apresentou melhor distribuição de tensão que os implantes infraósseo.

Palavras-chave: Implantes dentais; Prótese sobre implante; Análise fotoelástica; Pilares protéticos; Conexão cônica. 
Provinciatti, M.M. COMPARATIVE PHOTOELASTIC ANALYSIS BETWEEN STANDARD AND REGULAR ANKYLOS ABUTMENTS IN CONICAL ABUTMENT CONNECTION IMPLANTS INSTALLED IN DIFFERENT BONE DEPTHS. 2015. 105f. Dissertation (Master's Degree in Oral Rehabilitation) - Ribeirão Preto School of Dentistry, University of São Paulo, Ribeirão Preto, 2015.

Low-intensity stresses contribute to bone remodeling, while high intensity stresses cause bone resorption, below implant-abutment junction in dental implants. The occlusal overload affects the physiology of bone tissue, disrupting the balance between new formation and resorption. As a result of the disharmony, gaps arise in the crestal bone, creating a favorable environment for the proliferation of pathogens and fiber accumulation. With the continued overloading and the permanence of microorganisms, the bone support is impaired, resulting in implant failure. In normal loading conditions the tapered connection implants enables a homogeneous distribution of stresses. The subcrestal positioning of the prosthetic platform determines the transfer of stresses to distant areas from the cortical bone. This study used photoelastic analysis to evaluate the stress distribution in experimental models in conical abutment connection implants placed in equicristal position, $1.5 \mathrm{~mm}$ and $3.0 \mathrm{~mm}$ subcrestal positions. Rehabilitations were proposed for single prosthetic ceramic crowns cemented in standard and regular Ankylos prosthetic abutments with transmucosal height of $1.5 \mathrm{~mm}, 3.0 \mathrm{~mm}$ and $4.5 \mathrm{~mm}$. Implants were placed in the position corresponding to the first lower right molar. According to the chosen situations, sets of implant/abutments were evaluated separately, adjacent to replicas of the second lower right premolar and second lower right molar and just adjacent to replicas of the second right premolar. The load applied to the photoelastic models was $200 \mathrm{Ncm}$ in all cases. In models with dental replicas, distributed occlusal loading was performed; on models with isolated implant, loading was precise in the central and distal fossa of prosthetic crowns. The results showed that the indication of an abutment over another is depended on the presence or absence of a dental element posterior to the prosthetic crown, and of the implant platform depth of the remaining bone crest. In distal extension with subcrestal implants, stress distribution provided by Regular Ankylos prosthetic abutments was better than that provided by the Standard Ankylos abutment. With the presence of the second molar distribution of stress was more efficient with the Standard Ankylos abutment, regardless of the depth of the implant platform. In photoelastic models with distal extension, the platform displacement to a subcrestal position determined lower stress to the bone. Having bilateral proximal contacts, the stress distribution was favored when the implant was placed in a $3.0 \mathrm{~mm}$ subcrestal position with Regular Ankylos prosthetic abutments. However, when connected to the Standard Ankylos abutment, implant placed in equicristal position showed better stress distribution than subcrestal implants.

Keywords: Dental implants; Prosthesis on implants; Photoelastic analysis; Abutments; Conical connection. 
SUMÁRIO 


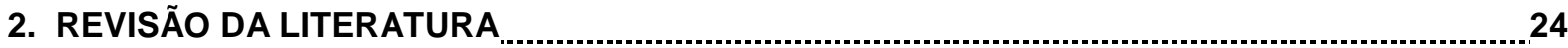

2.1 Implantes equicristais e infraósseo 25

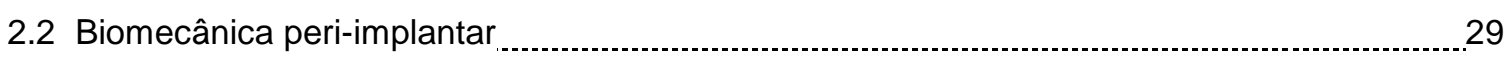

3. PROPOSIÇÃO

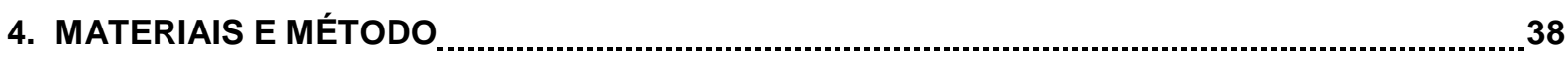

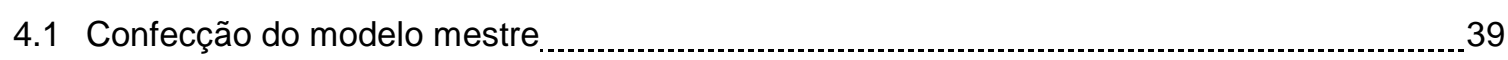

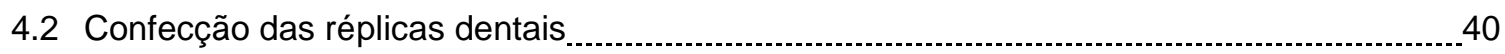

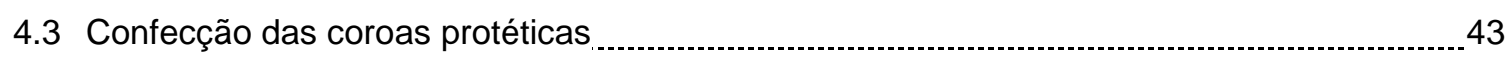

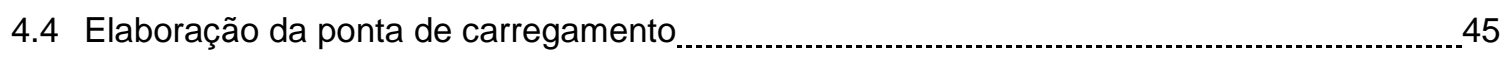

4.5 Confecção dos modelos fotoelásticos

4.6 Análise fotoelástica

5. RESULTADOS

5.1 Implante adjacente ao segundo pré-molar inferior e ao segundo molar inferior _.................... 53

5.1.1 Transmucoso de 1,5 mm (comparação entre pilar PP e S)

5.1.2 Transmucoso de 3,0 mm (comparação entre pilar PP e S) ..................................... 55

5.1.3 Transmucoso de 4,5 mm (comparação entre pilar PP e S) ........................................ 57

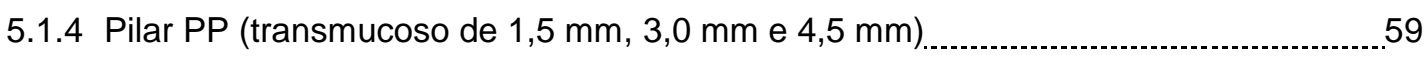

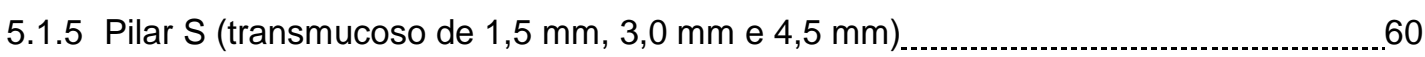

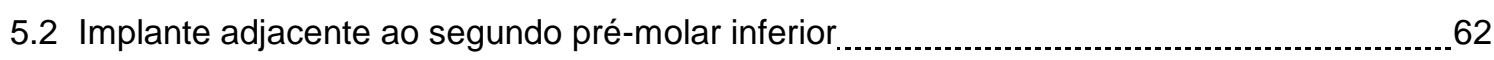

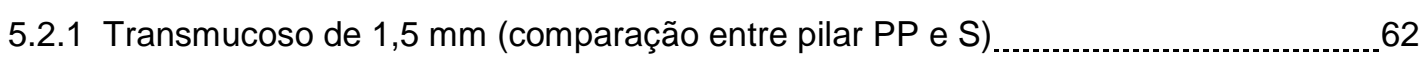

5.2.2 Transmucoso de 3,0 mm (comparação entre pilar PP e S).........................................6 63

5.2.3 Transmucoso de 4,5 mm (comparação entre pilar PP e S) ....................................... 65

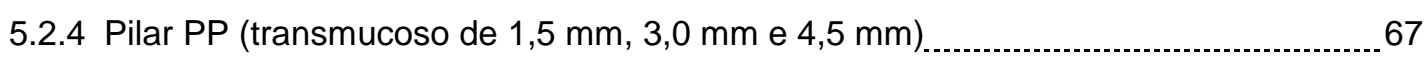

5.2.5 Pilar S (transmucoso de 1,5 mm, 3,0 mm e 4,5 mm) ................................................ 68

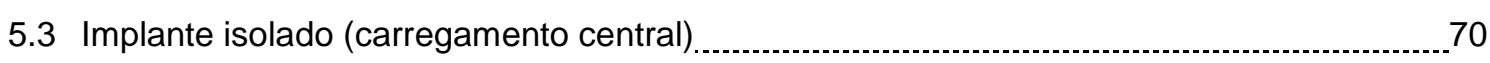

5.3.1 Transmucoso de 1,5 mm (comparação entre pilar PP e S) ..................................... 70

5.3.2 Transmucoso de 3,0 mm (comparação entre pilar PP e S) ................................. 71

5.3.3 Transmucoso de 4,5 mm (comparação entre pilar PP e S) ..................................... 73

5.3.4 Pilar PP (transmucoso de 1,5 mm, 3,0 mm e 4,5 mm) _.............................................. 75

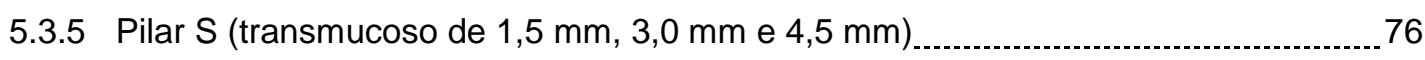

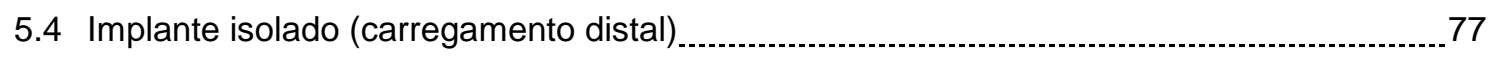

5.4.1 Transmucoso de 1,5 mm (comparação entre pilar PP e S) …................................ 77

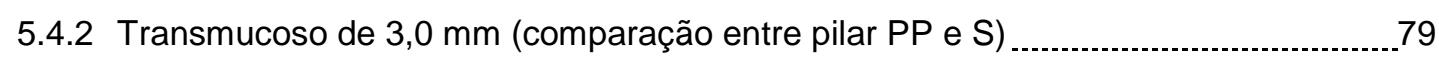

5.4.3 Transmucoso de 4,5 mm (comparação entre pilar PP e S) ........................................ 81

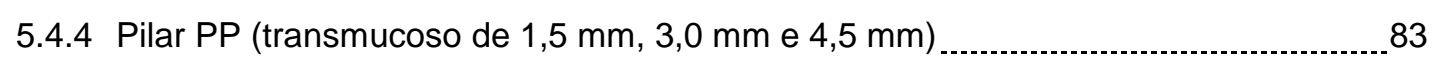

5.4.5 Pilar S (transmucoso de 1,5 mm, 3,0 mm e 4,5 mm)............................................ 84 
6. DISCUSSÃO

7. CONCLUSÃO

REFERÊNCIAS 
1. INTRODUÇÃO 
Os implantes osseointegráveis são recursos frequentemente utilizados no restabelecimento de dentes ausentes ou na substituição de elementos dentais com prognóstico desfavorável (LANG e SALVI, 2008). As reabilitações implantoprotéticas da cavidade oral estão entre os tratamentos mais bem sucedidos da medicina, com índices de sucesso em longo prazo superiores a 95\% (HAAS et al., 1995; GOODACRE et al., 2003; FUGAZZOTTO, 2005). O êxito das reabilitações provém de princípios estéticos e mecânicos, os quais são influenciados pela relação entre implante e tecido ósseo remanescente (ABUHUSSEIN et al., 2010). Para otimizar a relação é necessária a atenção quanto à técnica cirúrgica selecionada, à qualidade do leito ósseo receptor, ao desenho do implante, à superfície do implante e às condições de carregamento (ALBREKTSSON et al., 1981).

A obtenção e a manutenção da osseointegração estão relacionadas a dois conceitos, um biológico respaldado no comportamento do tecido ósseo frente aos acometimentos da placa bacteriana e um mecânico que compreende a sobrecarga oclusal no implante, com efeito sobre o osso subjacente (ABUHUSSEIN et al., 2010). Wolff (1892) associou a neoformação óssea com a transferência de cargas ao osso, por assim presumiu que com o aumento das tensões havia uma maior formação óssea, com a redução das tensões a reabsorção se tornava prevalente, sendo consequência da falta de estímulos ao tecido. Porém, posteriores descobertas mostraram que diante de elevadas tensões ocorria à reabsorção (FROST, 1990).

O carregamento oclusal adequado proporciona a remodelação óssea periimplantar, desde que as cargas aplicadas sobre as superfícies protéticas possuam baixa intensidade (ABUHUSSEIN et al., 2010). Em contrapartida, altas tensões motivam o surgimento de micro fraturas no tecido ósseo, desencadeando a osteoclastogênese (HANSSON e WERKE, 2003). A partir do desequilíbrio dos eventos biológicos com predomínio da reabsorção frente à neoformação, os primeiros defeitos ósseos se iniciam (PRENDERGAST e HUISKES, 1996). Em pouco tempo as lacunas ósseas são preenchidas por tecido fibroso e microrganismos (MISCH et al., 2001). Com a progressão das alterações o suporte ósseo é comprometido, resultando na falha do implante (BRUNSKI, 1999). A estabilidade da crista óssea é um aspecto essencial para a longevidade dos implantes osseointegráveis (CHOU et al., 2004).

O formato das roscas dos implantes determina a natureza da força que incide no rebordo ósseo, com a possibilidade de ser tração, compressão ou cisalhamento 
(ÇEHRELI et al., 2004a). Os implantes são planejados a partir do macro e micro desenho, o primeiro abrange questões relativas ao desenho das roscas, tais como profundidade, espessura e angulação. O segundo engloba o material que constitui os implantes e os tratamentos de superfície que os mesmos costumeiramente recebem (GENG et al., 2004a; GENG et al., 2004b). Essas concepções embasaram os achados de Chou et al. (2008) que observaram um aumento da densidade óssea nas extremidades das roscas, porém uma redução na superfície rugosa dos implantes.

A engenharia dos implantes assegura a obtenção da estabilidade primária no momento da instalação e permanece com a mesma relevância durante o carregamento funcional, as roscas em particular são projetadas para repassar ao osso somente tensões benéficas e para oferecer a maior área de contato possível ao tecido de suporte (ABUHUSSEIN et al., 2010). Bozkaya et al. (2004) realizaram estudo com metodologia de elementos finitos com cinco modelos distintos de sistemas de implantes, ao final os autores concluíram que as áreas de concentração das tensões variaram consideravelmente entre os sistemas. No entanto, as maiores tensões estiveram próximas ao osso cortical, sendo resultantes de vertentes axiais e laterais da carga oclusal.

A distribuição das tensões ao tecido ósseo decorre do tipo de conexão existente entre o implante e o pilar protético, com comprovada superioridade biomecânica das conexões internas (SUTTER et al., 1993; BALFOUR e O`BRIEN, 1995; MAEDA et al., 2006). Para a conexão cônica a dissipação homogênea das tensões se refere à inclinação da ligação interna, que faculta uma proeminente tolerância e resistência às forças laterais (SUTTER et al., 1993; MAEDA et al., 2006). As conexões hexagonais usam parafusos para estabilizar o pilar protético ao implante, a união entre os mesmos depende da pré-carga fornecida ao parafuso por meio de torque (BOZKAYA e MUFTU, 2003). O que representa um risco a integridade da união, uma vez que cargas oclusais com valores acima do torque da pré-carga podem causar o afrouxamento ou a deformação do parafuso (MERZ et al., 2000).

A reabsorção óssea peri-implantar também está ligada com a infiltração bacteriana e com os micro movimentos do pilar protético em relação ao implante, ambos são decorrências dos micro gaps presentes na interface de conexão (QUIRYNEN e VAN STEENBERGHE, 1993; QUIRYNEN et al., 1994; PERSSON et 
al., 1996). Nas conexões hexagonais células inflamatórias foram encontradas a 0,6 $\mathrm{mm}$ na direção apical e coronária da junção entre o implante e o pilar protético (DORING et al., 2004). A conexão cônica garante um alto grau de ajuste entre implante e pilar, limitando a colonização microbiana na interface de conexão (TESMER et al., 2009). Os micro movimentos também são menores, o que reflete na redução das taxas de afrouxamento de parafusos e de fraturas de componentes protéticos (NORTON, 2000; KHRAISAT et al., 2002; MANGANO et al., 2010).

As reabilitações implanto-protéticas com Plataforma Switching propiciam menor perda óssea peri-implantar (ATIEH et al., 2010), com simultânea manutenção da saúde do tecido mole (LUONGO et al., 2008). Na Plataforma Switching há um distanciamento da base de assentamento da prótese com a interface de conexão, permitindo que os tecidos circundantes permaneçam protegidos de agentes agressores (NOVAES et al., 2006; NOVAES et al., 2009). Os implantes com conexão cônica são configurados a partir da Plataforma Switching, a interface de conexão pode ser deslocada para uma posição infraóssea, definindo contornos anatômicos vantajosos à restauração (RODRIGUES e ROSENSTIEL, 2012).

Os pilares protéticos exibem variados desenhos a partir de distintos materiais, apesar das diferenças os pilares comumente buscam simplificar a conexão com o implante e facilitar a confecção da prótese (BABBUSH et al., 1987; RANGERT et al., 1991). A escolha por um determinado pilar depende de alguns critérios, entre eles 0 espaço interoclusal disponível, a posição e a angulação do implante, a anatomia dos tecidos moles e a estabilidade mecânica disponibilizada pelo exemplar (ENGELMAN, 1996). Os pilares metálicos fabricados em titânio são extremamente duráveis, o que os define como "padrão ouro" na implantodontia (PJETURSSON et al., 2007; SAILER et al., 2007). Porém, a coloração escura pode comprometer o resultado estético quando o tecido peri-implantar não for espesso (JUNG et al., 2008a).

O momento de flexão em pilares protéticos submetidos a carregamento estático está vinculado ao material que os compõem e ao tipo de conexão protética (LEUTERT et al., 2012). O pilar de titânio com conexão interna é mais resistente à fratura que o correspondente para a conexão externa (NORTON, 1997; KHRAISAT et al., 2002). Em pesquisa objetivando o carregamento funcional de pilares de titânio, Seetoh et al. (2011) encontraram alta incidência de fraturas dos componentes protéticos na porção localizada no interior dos implantes. Segundo os autores a 
condição se mostrou desfavorável para a intervenção, representando um desafio clínico significante aos odontólogos.

A fotoelasticidade como metodologia de pesquisa na odontologia teve como precursor Zak, o primeiro manuscrito a cerca do tema é datado de 1935, quando o autor averiguou questões referentes à movimentação dentária, às forças envolvidas no processo e aos pontos de aplicação. O método é amplamente usado no âmbito científico, sua aplicação se basea nos preceitos da óptica que permitem avaliar e mensurar a distribuição de tensão em estruturas submetidas a forças internas ou externas (MAIA et al., 2011). A pratica é possibilitada por materiais incolores, que sob carregamento e observados por luz polarizada emitem padrões de cores designados como franjas isocromáticas (MARKARIAN et al., 2007; GOIATO et al., 2009).

Entre os métodos para análise de tensão, a fotoelasticidade é adequada para avaliar implantes osseointegráveis, considerando para tanto a incorporação dos mesmos em modelos de simulação de osso e a aplicação de cargas de acordo com os valores desejados (KINNI et al., 1987; CAPUTO e STANDLEE, 1987). Em condições de carregamento similares ao da cavidade oral é possível identificar falhas em estruturas expostas ao stress, inclusive as com geometria irregular (ASVANUND e MORGANO, 2011). A preparação dos materiais fotoelásticos demanda cuidados cruciais (ÇEHRELI et al., 2013). Exceder o limite de fotoelasticidade do material, posicionar erroneamente o modelo para a aplicação da carga, definir formatos incorretos ao modelo e desconsiderar a presença de tensões prévias podem acarretar resultados equivocados (MAHLER e PEYTON, 1955; CAMPOS JR. et al., 1986).

São limitadas as informações disponíveis na literatura a cerca do processo de distribuição de tensão em implantes com conexão cônica instalados em diferentes profundidades na crista óssea, estando conectados a pilares protéticos sólidos e de parafuso passante. O presente estudo utilizou a análise fotoelástica para avaliar a distribuição de tensão no tecido ósseo subjacente a implantes com conexão cônica instalados na região posterior de mandíbula, a fim de definir a influência da profundidade dos implantes na crista óssea e a dos desenhos dos pilares protéticos na dinâmica de dissipação das cargas aplicadas em coroas unitárias de cerâmica. 
2. REVISÃO DA LITERATURA 


\subsection{Implantes equicristais e infraósseo}

O desenho do implante deve possibilitar a confecção de próteses resistentes e duráveis, com formatos e contornos similares a coroas e pônticos cimentados sobre dentes naturais, restaurações que atendam a requisitos funcionais e estéticos mesmo tendo decorrido um período significativo do término do tratamento (WEIGL, 2004). Nas reabilitações implanto-protéticas a estética pode ser obtida por meio do posicionamento infraósseo da plataforma do implante, nesta circunstância o perfil de emergência da prótese e a acomodação do tecido mole são beneficiados (BUSER et al., 1993). Em áreas que requerem cuidados estéticos, a presença mínima de osso sobre a plataforma do implante define resultados relevantes à reabilitação proposta (NOVAES et al., 2009).

Com o posicionamento infraósseo da plataforma a probabilidade de exposição da superfície do pilar protético é menor (NOVAES et al., 2006). Outra vantagem adquirida se refere à formação e à manutenção de picos de crista óssea nas regiões interimplantares, garantindo a estabilidade das papilas (NOVAES et al., 2009). Barros et al. (2010) avaliaram em cães os efeitos na arquitetura óssea para as distâncias mesio-distais de $2 \mathrm{~mm}$ e $3 \mathrm{~mm}$ estabelecidas entre implantes com conexão cônica instalados nas posições equicristal e infraóssea a 1,5mm. Os autores concluíram que não houve diferença na remodelação óssea ao alterar a distância entre os implantes, porém a posição da plataforma do implante no rebordo foi preponderante para acarretar o achatamento das cristas ósseas interimplantares nos implantes equicristais contíguos.

Os primeiros implantes com a plataforma protética inserida na posição infraóssea tiveram por propósito aprofundar a porção lisa e polida dos implantes, a fim de compensar a reabsorção óssea vertical observada com frequência nos implantes equicristais (ALBREKTSSON et al., 1986; HARTMAN e COCHRAN, 2004; ROOS-JANSAKER et al., 2006). Hammerle et al. (1996) inseriram a linha de transição da porção áspera com a porção lisa e polida dos implantes nas posições equicristal e infraóssea. A reabsorção óssea ocorrida nos implantes infraósseo foi o dobro da encontrada nos implantes com a linha de transição na posição equicristal.

Hartman e Cochran (2004) inseriram a linha de transição nas posições infraóssea, equicristal e supracristal. Radiografias digitalizadas realizadas no dia da instalação dos implantes, seis meses após as cirurgias e anualmente por cinco anos 
revelaram que a maior remodelação óssea aconteceu nos seis primeiros meses, independentemente do posicionamento dos implantes na crista óssea. Contudo, diferenças expressivas de reabsorção óssea foram confirmadas entre os grupos avaliados, para os implantes equicristais e supracristais a reabsorção óssea correspondeu em média a 0,68 mm, para os implantes infraósseo a média foi de $1,72 \mathrm{~mm}$.

Pontes et al. (2008) em estudo com cães propuseram a instalação de implantes com conexão hexagonal interna em distintas profundidades na crista óssea, ocupando as posições equicristal, infraóssea a $1 \mathrm{~mm}$ e infraóssea a $2 \mathrm{~mm}$. Os implantes em questão foram submetidos a carregamento imediato ou tardio. As análises clínicas e radiográficas demonstraram que o primeiro contato entre o osso e o implante foi firmado mais apicalmente para os implantes infraósseo. Assim como também que os maiores defeitos ósseos estavam relacionados com a posição infraóssea dos implantes.

Stein et al. (2009) utilizaram implantes com conexão hexagonal interna e externa em reabilitações unitárias na região anterior de maxila. Os referidos implantes apresentavam variados padrões de macro e micro desenho do colar cervical. Foi avaliada no estudo a correlação entre a profundidade do implante no rebordo remanescente e a reabsorção óssea do leitor receptor. Ao final de cinco anos, período designado para o acompanhamento dos pacientes, foi concluído que o posicionamento infraósseo da plataforma dos implantes com conexão hexagonal implicou no aumento da reabsorção óssea peri-implantar.

Os resultados alcançados com os implantes com conexão hexagonal na posição infraóssea não incentivaram a continuidade da prática, existia uma relação notória entre implante infraósseo e reabsorção óssea peri-implantar (HAMMERLE et al., 1996; STEIN et al., 2009). O contexto criado foi somente alterado com o desenvolvimento de implantes com desenho cônico, roscas progressivas e plataformas ásperas (WENG et al., 2008; DEGIDI et al., 2010; ROMANOS et al., 2010). Essas mudanças impulsionaram novos estudos em animais e humanos, com resultados positivos quanto a manutenção da integridade do tecido ósseo subjacente a implantes infraósseo (WENG et al., 2008; DEGIDI et al., 2010; ROMANOS et al., 2010).

Doring et al. (2004) reabilitaram com coroas unitárias 275 implantes com conexão cônica instalados em regiões anteriores e posteriores de maxila. Após o 
acompanhamento médio dos pacientes por trinta e oito meses, a taxa de sucesso para os implantes foi definida em 98,2\%, com a falha de apenas cinco implantes. Os autores ressaltaram que exames por imagem realizados ao final da etapa de acompanhamento revelaram que $50 \%$ dos implantes possuíam osso até a altura da plataforma ou ligeiramente acima desta.

Chou et al. (2004) acompanharam a reabsorção óssea em implantes com conexão cônica por trinta e seis meses, compreendendo o período entre a instalação e o carregamento funcional. $\mathrm{Na}$ fase de cura os implantes permaneceram submersos. Na reabertura para a colocação dos pilares protéticos, sondas periodontais registraram uma reabsorção óssea média de $0,7 \mathrm{~mm}$, cuja origem foi relativa ao trauma cirúrgico da instalação dos implantes. Entre a inserção dos pilares e o carregamento das próteses uma reabsorção óssea média de $0,11 \mathrm{~mm}$ foi observada, sendo ainda consequência do trauma cirúrgico. Decorrido três anos do carregamento, a reabsorção óssea média no entorno dos implantes foi estabelecida em 0,6 mm.

Donovan et al. (2010) alcançaram 100\% de sucesso utilizando implantes com conexão cônica na reabilitação de 50 indivíduos parcialmente edêntulos. Todos os implantes foram instalados na posição infraóssea, em média as plataformas protéticas dos implantes estavam a 1,37 $\mathrm{mm}$ e a 1,28 $\mathrm{mm}$ do pico ósseo interproximal mesial e distal respectivamente. Com doze meses da instalação dos implantes, os autores constataram que a reabsorção óssea média foi de 0,11 mm e que em $69 \%$ dos implantes houve a manutenção do contato do tecido ósseo com a plataforma protética.

Weng et al. (2008) instalaram implantes com conexão hexagonal externa e cônica em mandíbulas de cães. Um exemplar de cada conexão ocupou a posição equicristal e infraóssea a 1,5 mm, permanecendo submersos durante os três meses referentes ao período de cura. Posteriormente às reaberturas, os cicatrizadores foram mantidos por mais três meses. Quanto à posição equicristal, não houve diferença significativa na configuração final do osso peri-implantar para as distintas conexões. Entretanto, para a posição infraóssea os implantes com conexão cônica apresentaram reabsorção óssea de apenas $0,6 \mathrm{~mm}$. Outro fato visualizado durante as avaliações histológicas foi o contato do osso com o cicatrizadores nos implantes com conexão cônica. 
Tran et al. (2010) demostraram em cães a importância do posicionamento infraósseo dos implantes quando são instalados em alvéolos dentários com defeitos ósseos. A simulação de alvéolos dentários com defeitos foi por intermédio da criação de espaços excedentes entre a plataforma do implante e as laterais do preparo cirúrgico. Análises histológicas realizadas um mês após a instalação dos implantes sugeriram que o contato entre o osso e o implante firmado nas áreas de defeito ósseo foi superior nos implantes infraósseo a $2 \mathrm{~mm}$, quando comparados com os implantes equicristais.

Luo et al. (2012) acompanharam entre trinta e seis e oitenta e cinco meses pacientes reabilitados com implantes com conexão cônica na região posterior de mandíbula. A plataforma protética dos implantes foi posicionada em diferentes profundidades no rebordo remanescente. Radiografias panorâmicas foram usadas como instrumento para mensurar a reabsorção óssea ocorrida na periferia dos implantes. Com base na análise dos exames por imagem foi definido que os implantes infraósseo apresentavam maior probabilidade de manter a estabilidade do tecido ósseo.

Dependendo do fabricante, as orientações podem divergir quanto ao posicionamento da plataforma do implante na crista óssea. O protocolo do sistema Ankylos (Dentsply Implants, Alemanha) prevê que a plataforma do implante deve estar entre 1,5 mm e 2,0 mm infraóssea, com o propósito de criar um perfil de emergência adequado. Entretanto, a flexibilidade prática do sistema permite que o implante seja instalado em profundidades maiores, sem quaisquer danos ao tecido duro e mole (DORING et al., 2004). Em condição limitante de osso, o implante pode ser instalado na posição equicristal e mesmo assim favorecer o desenvolvimento de tecido mole alto e espesso (WEIGL, 2004).

O tecido gengival peri-implantar se assemelha em muitos aspectos com o periodontal (COCHRAN, 1996). Tenenbaum et al. (2003) avaliaram a morfologia peri-implantar de implantes com conexão cônica, os achados confirmaram a existência de um epitélio queratinizado constituído por inúmeras camadas de células epiteliais e sulcos forrados por células epiteliais não queratinizadas. No tecido conjuntivo as fibras colágenas possuíam diferentes direções. As verticais partiam do periósteo e da crista óssea em direção ao epitélio oral, as perpendiculares foram encontradas com menor frequência, mas quando presentes estavam em contato direto com o implante e o pilar. 
Huang et al. (2015) estudaram em cães diferentes sistemas de implantes com conexão cônica instalados nas posições equicristal e infraóssea a 1,5 mm. Os pilares protéticos foram inseridos três meses após as cirurgias, permanecendo na cavidade oral por cerca de um mês. Ao término da pesquisa foi concluído que nos implantes infraósseo houve a formação de epitélio com maior comprimento do que o visto nos implantes equicristais. O que implicou na maior profundidade de sondagem nos implantes infraósseo e na necessidade de determinar as dimensões do epitélio, a fim de acompanhar a saúde peri-implantar a longo prazo.

\subsection{Biomecânica peri-implantar}

A interface de conexão entre o implante e o pilar protético é caracterizada pela fragilidade, contudo cabe a ela resistir à penetração bacteriana e manter a estabilidade da conexão frente às intemperes da carga mastigatória (SCHMITT et al., 2014). Planejamentos implanto-protéticos utilizando implantes com conexão cônica na posição infraóssea determina a transferência da interface para a posição subcristal, tal medida resulta na redução da reabsorção óssea peri-implantar e contribui para a formação de tecido epitelial e conjuntivo espessos (TODESCAN et al., 2002; WELANDER et al., 2009).

$\mathrm{Na}$ conexão cônica a relação dimensional horizontal entre pilar protético e implante é alterada a partir da diminuição do diâmetro do pilar, esta configuração recebe o nome de Plataforma Switching (LAZZARA e PORTER, 2006). A Plataforma Switching respaldou o desenvolvimento de desenhos de pilares protéticos e implantes, objetivando a estabilidade mecânica, a qual influenciou a distribuição das tensões, a manutenção da posição original dos tecidos, a eliminação de micro gaps, a limitação da proliferação bacteriana e a ausência de movimentos do componente protético em relação ao implante (NENTWIG, 2004).

Hurzeler et al. (2007) compararam a reabsorção óssea em implantes com e sem Plataforma Switching. Para os implantes com Plataforma Switching a reabsorção óssea média foi de 0,22 $\pm 0,53 \mathrm{~mm}$, ao passo que para os implantes sem Plataforma Switching a média correspondeu a 2,02 $\pm 0,49 \mathrm{~mm}$, sendo os valores registrados após as próteses completarem um ano de função. Os resultados citados anteriormente foram próximos aos relatados por Vela-Nebot et al. (2006), os implantes do grupo teste com Plataforma Switching atingiram reabsorção óssea 
média de 0,76 mm, enquanto que no grupo controle com implantes sem Plataforma Switching a média foi de $2,53 \mathrm{~mm}$.

Wagenberg e Froum (2010) acompanharam por onze anos 94 implantes com Plataforma Switching, ao final do período os autores concluíram que em $75 \%$ dos implantes não ocorreu reabsorção óssea peri-implantar, do restante $88 \%$ apresentou reabsorção igual ou menor à 0,8 mm. Rodriguez-Ciurana et al. (2009) utilizaram 41 pares de implantes com Plataforma Switching em 37 pacientes devidamente selecionados para tratamentos restauradores. Durante a fase de acompanhamento, os exames por imagem mostraram que acima da interface de conexão havia em média 2,4 mm de osso.

Degidi et al. (2008) avaliaram por meio da microscopia eletrônica a histofisiologia de um implante com Plataforma Switching recuperado da cavidade oral humana, após permanecer em função por um mês. O contato entre o osso e o implante foi estabelecido em $65,3 \%$, justificado pelo tratamento de superfície do implante através de processos de jateamento e corrosão. Outros autores realizaram testes precursores com o mesmo modelo de implante alcançando resultados semelhantes. Nentwig (2004) relacionou seus achados com a transmissão favorável das tensões ao tecido ósseo. Para Doring et al. (2004) o diferencial foi a presença de uma espessa e macia camada de tecido conjuntivo fibroso ao redor do estreito pescoço do pilar protético.

A escolha da conexão protética é relevante no planejamento e na execução das reabilitações implanto-protéticas (PIERMATTI et al., 2006). A integridade da união do pilar protético com o implante na conexão cônica advém da formação de uma solda fria (RICOMINI FILHO et al., 2010; KOUTOUZIS et al., 2011), proporcionada pelo atrito entre o pilar e o implante (BALSHI et al., 1997) e pela angulação dos distintos cones (WEIGL, 2004). A conexão cônica se mostrou eficiente para a confecção de próteses unitárias, parciais e totais (ADELL et al., 1990; CREUGERS et al., 2000; NAERT et al., 2001).

Os defeitos "em forma de prato" no tecido ósseo peri-implantar foram colocados como um processo de remodelação óssea no entorno dos micro gaps existentes entre o implante e o pilar protético (WENG et al., 2008). Sendo resultado do restabelecimento das distâncias biológicas, a fim de manter o osso afastado dos tecidos contaminados, promovendo um selamento biológico propriamente dito (ERICSSON et al., 1995). Entretanto, a reabsorção óssea peri-implantar após um 
ano do implante em função pode ter como causa o deslocamento das bactérias colonizadoras dos micro gaps em direção aos tecidos adjacentes (PIATTELLI et al., 2001).

A proximidade dos micro gaps com o osso circundante viabiliza a progressão das inflamações peri-implantares (TESMER et al., 2009). Modelos experimentais com conexão hexagonal revelaram através de exames radiográficos que o primeiro contato entre o osso e o implante aconteceu a uma distância de $2 \mathrm{~mm}$ dos micro gaps (HERMANN et al., 1997). Com as avaliações histológicas foi possível obter maior precisão, firmando que o primeiro contato entre o osso e o implante se manteve a uma distância entre 1,3 a 2,6 mm dos micro gaps quando da utilização da conexão hexagonal (HERMANN et al., 2000).

O potencial de colonização bacteriana dos micro gaps se baseia em alguns critérios, dentre eles a precisão de ajuste entre o implante e o pilar protético, as forças de torção usadas para conecta-los e as cargas as quais o conjunto implante/pilar está sujeito durante a função (TESMER et al., 2009). Não há qualquer conexão protética que ofereça um vedamento hermético da interface de conexão (RICOMINI FILHO et al., 2010; ASSENZA et al., 2012). Porém, o tipo de conexão protética selecionada determina a quantidade de bactérias que penetram e se proliferam na porção interna do implante (TESMER et al., 2009).

As dimensões dos micro gaps variam de acordo com a conexão protética. Nas conexões hexagonais, Keith et al. (1999) relataram medidas entre 40 e 100 micrômetros, Hermann et al. (2001) na ordem de 10 a 100 micrômetros. Na conexão cônica as grandezas se alteram substancialmente, Jansen et al. (1997) avaliaram conexões com micro gaps entre 1 e 2 micrômetros, Dibart et al. (2005) entre 1 e 3 micrômetros. Clinicamente em ambos os estudos, os autores observaram a manutenção da crista óssea nas alturas originais e a leve inflamação do tecido mole, sendo resultado da condição implanto-protética alcançada pelo uso da conexão cônica com micro gaps reduzidos.

Jansen et al. (1997) incubaram Escherichia coli na porção interna de implantes com conexão cônica e hexagonal, posteriormente conectaram os pilares protéticos. Os autores confirmaram que 50\% dos implantes com conexão cônica permitiram a passagem de bactérias para a superfície externa, nos implantes com conexão hexagonal a taxa correspondeu a 82\%. Tesmer et al. (2009) analisaram a penetração de A. actinomycetemcomitans na interface de conexão protética de 
implantes com conexão cônica e hexagonal interna, os achados foram que em 30\% dos implantes com conexão cônica e 90\% dos implantes com conexão hexagonal interna houve infiltração bacteriana.

$\mathrm{Na}$ conexão hexagonal externa as forças exercidas na prótese se concentram no parafuso central que mantém o pilar protético em posição (MANGANO et al., 2009). Nos sistemas com conexão cônica, dependendo do pilar protético escolhido também há parafuso de fixação. Entretanto, nesta situação o parafuso permanece protegido das forças e sua função se relaciona à manutenção inicial de contato entre pilar e implante (WEIGL, 2004). A alta estabilidade mecânica da conexão cônica permite a cimentação de coroas e pônticos sem riscos eminentes de afrouxamento dos pilares se comparado com outros tipos de conexão protética (WEIGL, 2004).

A continuidade em longo prazo do torque fornecido à conexão cônica é superior à octogonal interna (RICOMINI FILHO et al., 2010) e à hexagonal externa (PARK et al., 2010). Para a conexão hexagonal externa, a incidência de afrouxamento do parafuso dos pilares protéticos em implantes instalados na região posterior de mandíbula correspondeu a 40\% (JEMT et al., 1991; BECKER e BECKER, 1995). Walton e MacEntee (1997) relataram afrouxamento de parafusos de pilares com conexão hexagonal externa em $27 \%$ das próteses fixas e em $32 \%$ das próteses móveis. Nas próteses unitárias a frequência foi ainda maior, Ekfeldt et al. (1994) observaram que no período de três anos $43 \%$ dos parafusos apresentaram algum grau de afrouxamento.

Ding et al. (2003) encontraram pouca alteração no torque inicial aplicado em parafusos de pilares protéticos com conexão cônica submetidos a carregamento. Levine et al. (1999) descreveram um afrouxamento entre 3,6\% e 5,3\% de pilares cônicos usados em restaurações unitárias cimentadas, resultados similares foram mostrados por Morgan e Chapman (1999). Mangano et al. (2009) durante estudo multicentro acompanharam por quatro anos 307 implantes com conexão cônica reabilitados com próteses unitárias, apenas em $0,65 \%$ dos pilares houve afrouxamento.

Os implantes com conexão cônica distribuem de forma favorável a tensão às estruturas ósseas adjacentes (BAGGl et al., 2008; TABATA et al., 2010), com redução dos picos de tensão em áreas criticas, tais como osso cervical cortical e trabeculado apical (HANSSON, 2000; LIN et al., 2007; QUARESMA et al., 2008). Pessoa et al. (2010) documentaram resultados positivos na dissipação de tensão 
quando a conexão cônica foi utilizada e resultados de menor expressão com as conexões hexagonais internas e externas.

Em determinados sistemas com conexão cônica, a junção dos componentes propicia propriedades mecânicas que mantém a estabilidade da união até mesmo sob a ação de forças oblíquas, promovendo uma distribuição de tensão uniforme ao longo do pilar e reduzindo os esforços que agem no parafuso central (WEIGL, 2004). Essas características possivelmente motivaram os resultados de Nentwig (2004), que durante o carregamento de implantes com conexão cônica identificou reabsorção óssea cervical em menos de $20 \%$ dos implantes e mesmo nestes a reabsorção foi considerada mínima.

São escassos os estudos que comparam o desempenho biomecânico de pilares protéticos sólidos com os de parafuso passante para implantes com conexão cônica instalados em diferentes profundidades ósseas. Pellizzer et al. (2014) analisaram a dissipação de tensão em cinco sistemas de implantes por intermédio da fotoelasticidade, os autores notaram que a maior diferença entre os sistemas quanto a distribuição das tensões ocorreu no terço cervical e apical dos implantes submetidos a cargas axiais. Fato relacionado ao desenho dos implantes, ao tipo de conexão protética e a presença ou não de roscas até a plataforma. O melhor desempenho foi dos implantes com conexão cônica, segundo os conceitos biomecânicos o achado representou a possibilidade de controle da saucerização (BRUNSKI, 1999; MISCH e STRONG, 1999).

Chu et al. (2011) usaram modelos experimentais sintéticos para simular o tecido ósseo com diferentes espessuras de cortical. Nos modelos foram instalados implantes com conexão cônica nas posições equicristal e infraóssea a $1 \mathrm{~mm}$. Os pilares protéticos cônicos conectados aos implantes receberam cargas de $170 \mathrm{~N}$, aplicadas na direção axial e oblíqua. Os picos de tensão surgiram distantes da crista óssea para os implantes infraósseo, porém para os implantes equicristais se configurou o oposto. A variação dos resultados confirmou a influência da posição da interface de conexão na crista óssea no processo de reabsorção óssea periimplantar.

A resistência das conexões protéticas também depende da direção (WEIGL, 2004) e da intensidade dos vetores de força (BOZKAYA et al., 2004). Para os pilares de parafuso passante, as forças horizontais representam um risco relevante (WEIGL, 2004). Rigsby et al. (1998) definiram que as maiores forças que recaiam em coroas 
unitárias estavam na direção axial, com valores entre $77 \mathrm{~N}$ e $2240 \mathrm{~N}$. Em contrapartida, Holmgren et al. (1998) por intermédio da análise de elementos finitos estabeleceram que os maiores picos de tensão no osso cortical ocorreram durante a oclusão oblíqua, apesar de Brunski (1997) assegurar previamente que as forças de natureza oblíqua possuíam valores inferiores a $100 \mathrm{~N}$.

Em virtude da liberdade de rotação inerente à conexão hexagonal externa, o carregamento oblíquo acaba por concentrar as tensões na porção cervical dos implantes, resultando em reabsorção óssea (SUTTER et al., 1993; BALFOUR e O`BRIEN, 1995; MAEDA et al., 2006). Em circunstâncias similares à descrita anteriormente, modelos fotoelásticos mostraram que as tensões se concentraram no osso cortical do lado oposto ao da aplicação das cargas oblíquas (FRENCH et al., 1989; ÇEHRELI et al., 2004b). Em compensação, a conexão cônica foi planejada para resistir às forças não axiais que agem nos pilares protéticos, resguardando de sobrecarga o tecido ósseo peri-implantar (WEIGL, 2004).

Çehreli et al. (2004b) estudaram a resistência da conexão cônica à fadiga, conjuntos de implante/pilar foram submetidos a 500.000 ciclos de carga e recarga, ao final não foram relatadas quaisquer espécimes de falhas para a conexão. Com metodologia semelhante, Khraisat et al. (2002) compararam a conexão cônica com a hexagonal externa. A superioridade da conexão cônica foi comprovada, assim como a fragilidade da conexão hexagonal externa, uma vez que a mesma apresentou fraturas de componentes protéticos tendo decorrido entre 1733 e 1778 ciclos de carregamento.

Distintos sistemas de implantes (Ankylos, ITI, Nobel Biocare, Astra e Bicon) foram avaliados por análise de elementos finitos quanto à concentração de tensão de compressão e de tração na interface do osso cortical com o implante, quando da aplicação de cargas de diferentes magnitudes em variadas direções. A melhor distribuição de tensão foi com a conexão cônica do sistema Ankylos, que dependendo da direção da força apresentou pouca ou nenhuma sobrecarga ao tecido ósseo. Segundo os autores, o estreitamento da secção transversal do implante na porção coronal motivou a distribuição homogênea da tensão (BOZKAYA et al., 2004).

Com o objetivo de reduzir as tensões transferidas aos implantes, a ferulização de coroas protéticas adjacentes se tornou uma prática comum nas reabilitações, entretanto a esplintagem não impede que picos de tensão provenientes de forças 
horizontais sejam direcionados individualmente aos implantes (RANGERT, 1993; RANGERT et al., 1995). As coroas ferulizadas facilitam o acúmulo de resíduos alimentares nos conectores e dificultam o acesso para a higienização, sendo assim quando as estruturas ósseas permitirem é preferível o uso de um implante por dente ausente e a confecção de próteses isoladas uma das outras (WEIGL, 2004).

Degidi et al. (2011) analisaram histologicamente implantes com conexão cônica recuperados da cavidade oral humana entre quatro e oito semanas após a instalação, neste período os implantes receberam carga contínua. Além da posição equicristal, a profundidade dos implantes na crista óssea variou entre $1 \mathrm{~mm}$ e $3 \mathrm{~mm}$. As imagens microscópicas de um dos conjuntos de pilar/implante cuja interface de conexão estava infraóssea revelaram o íntimo contato ósseo com a superfície metálica do pilar protético. O trabeculado tinha uma direção de desenvolvimento ápico-coronal estabelecida desde a plataforma do implante até contatar a porção inferior da restauração, havendo a deposição de matriz óssea e a presença de osteoblastos ao longo do metal.

Em cães, Welander et al. (2009) avaliaram as consequências de modificações realizadas na superfície de pilares protéticos e na porção cervical de implantes com conexão cônica. Os implantes foram instalados a $2 \mathrm{~mm}$ infraósseo e ao final das cirurgias os pilares protéticos inseridos. Após quatro meses em função, as análises histológicas do material coletado determinaram que em $40 \%$ dos pilares ocorreu contato ósseo na superfície metálica. Foi concluído que até então a lisura dos pilares não permitia a aproximação óssea, mesmo estando à interface de conexão em uma posição infraóssea. Paralelamente também foi definida a possibilidade de conseguir osseointegração e tecido mole saudável em implantes com micro gaps menores, desde que existisse uma superfície apropriada. 
3. Proposição 
O presente estudo teve como objetivo geral avaliar por intermédio da análise fotoelástica a distribuição de tensão no entorno de implantes com conexão cônica conectados a pilares protéticos sólidos e de parafuso passante.

Os objetivos específicos foram:

- Comparar o desempenho biomecânico entre pilares protéticos sólidos e de parafuso passante.

- Avaliar a distribuição de tensão no entorno de implantes com conexão cônica instalados em diferentes profundidades ósseas. 
Para o presente estudo foram selecionados dois modelos de pilares protéticos com distintos mecanismos de conexão ao implante: S - pilar sólido (Standard C/, ANKYLOS®, Dentsply Implants, Mannheim, Alemanha) e PP - pilar de parafuso passante (Regular C/X, ANKYLOS®, Dentsply Implants, Mannheim, Alemanha), ambos indicados para reabilitações com próteses unitárias cimentadas na região posterior de mandíbula. Os pilares protéticos em questão foram conectados a implantes de conexão cônica (Driver, Ankylos®), Dentsply Implants, Mannheim, Alemanha). Os itens que variaram entre as situações analisadas foram relacionados na tabela 1.

Tabela 1 - Itens de variação

\begin{tabular}{|c|c|c|c|c|c|}
\hline Pilar & $\begin{array}{c}\text { Altura } \\
\text { Cervico-Oclusal } \\
(\mathbf{m m})\end{array}$ & $\begin{array}{c}\text { Base de } \\
\text { assentamento } \\
\text { da prótese }(\mathrm{mm})\end{array}$ & $\begin{array}{c}\text { Transmucoso } \\
(\mathrm{mm})\end{array}$ & $\begin{array}{l}\text { Implante } \\
(\mathrm{mm})\end{array}$ & $\begin{array}{l}\text { Profundidade } \\
\text { do Implante } \\
\text { (mm) }\end{array}$ \\
\hline \multirow{3}{*}{$\mathrm{S}$} & \multirow{3}{*}{4} & \multirow{3}{*}{3,3} & 1,5 & \multirow{6}{*}{$\varnothing 3,5 \times 9,5$} & Equicristal \\
\hline & & & 3,0 & & 1,5 \\
\hline & & & 4,5 & & 3,0 \\
\hline \multirow{3}{*}{ PP } & \multirow{3}{*}{$\begin{array}{c}\text { Ajustável - 6,6 } \\
\text { (após ajuste 4,5) }\end{array}$} & \multirow{3}{*}{4,5} & 1,5 & & Equicristal \\
\hline & & & 3,0 & & 1,5 \\
\hline & & & 4,5 & & 3,0 \\
\hline
\end{tabular}

A metodologia empregada na confecção e análise dos modelos fotoelásticos será descrita na sequência.

\subsection{Confecção do modelo mestre}

O modelo mestre (Figura 1) utilizado foi confeccionado com dimensões de 68 x 30 x 14 mm (ALVES, 2013). As perfurações criadas no modelo mestre, posteriormente ocupadas pelas réplicas dentais e pelo análogo do implante foram feitas segundo os seguintes critérios. Entre os centros das perfurações correspondentes ao segundo molar e ao implante havia uma distância de $12 \mathrm{~mm}$, entre os do implante e o do segundo pré-molar $9 \mathrm{~mm}$. Isso permitiu que as coroas protéticas, assim como a porção coronal das réplicas dentais tivessem medidas mesio-distais compatíveis com as de dentes naturais. A plataforma do análogo do implante permaneceu na posição equicristal. Quanto à profundidade das perfurações foi estabelecido que deveriam ser o suficiente para acomodar as raízes das réplicas até a linha cemento-esmalte e o análogo do implante em toda a sua extensão. 


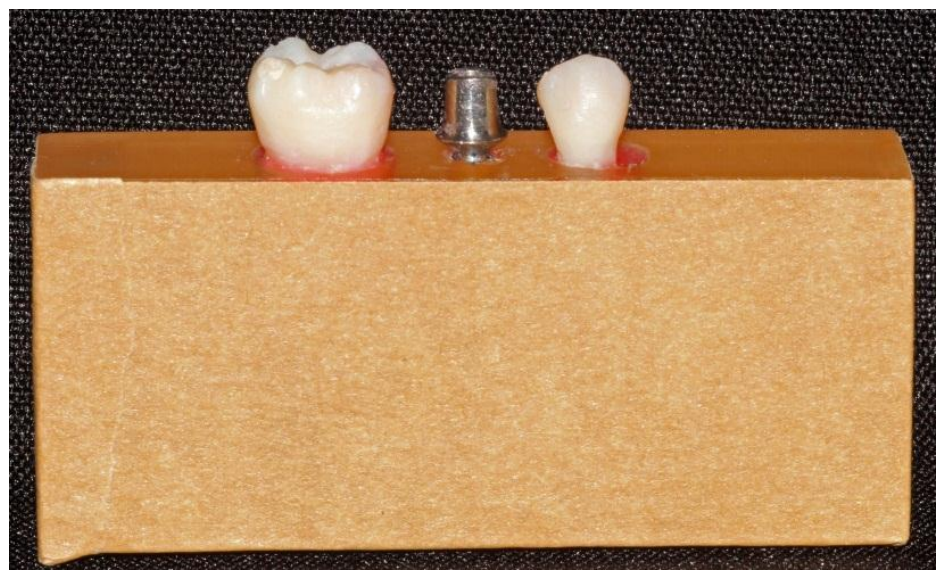

Figura 1- Modelo mestre com o análogo do implante, pilar protético PP e réplicas dentais.

\subsection{Confecção das réplicas dentais}

Inicialmente foram esculpidas duas réplicas dentais em resina bisacrílica autopolimerizável (Protemp, 3M ESPE, Seefeld, Alemanha), uma do segundo prémolar inferior direito e outra do segundo molar inferior direito. A elas foram fornecidos contornos similares a de dentes naturais correspondentes. Depois dos acabamentos as réplicas foram moldadas com silicona de condensação (Zetalabor, Zhermack, Rovigo, Itália), a fim de criar moldes para a reprodução de novas réplicas dentais (Figura 2) usadas para compor os modelos fotoelásticos.

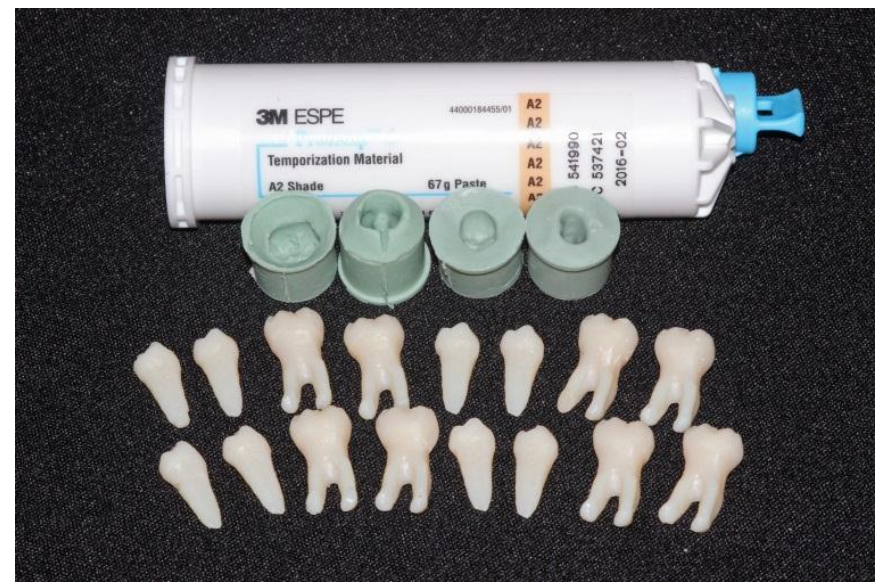

Figura 2 - Réplicas dentais confeccionadas a partir de moldes de silicona de condensação.

Duas das réplicas foram fixadas à haste do paralelômetro (Figura 3: $A-B$ ). As mesmas foram rapidamente imersas e retiradas do plastificador (Figura 4: A-B) com 
cera para escultura (Shuler Dental, Ulm, Alemanha). Com a manobra formou-se no entorno das raízes uma película de cera com espessura de 0,25 mm (TIOSSI, 2010). Na sequência, a silicona de condensação foi manipulada e as raízes envoltas pela cera inseridas no material de moldagem. Atingida a polimerização da silicona as réplicas foram removidas, obtendo-se moldes (Figura 5: A-B) para a simulação do ligamento periodontal.
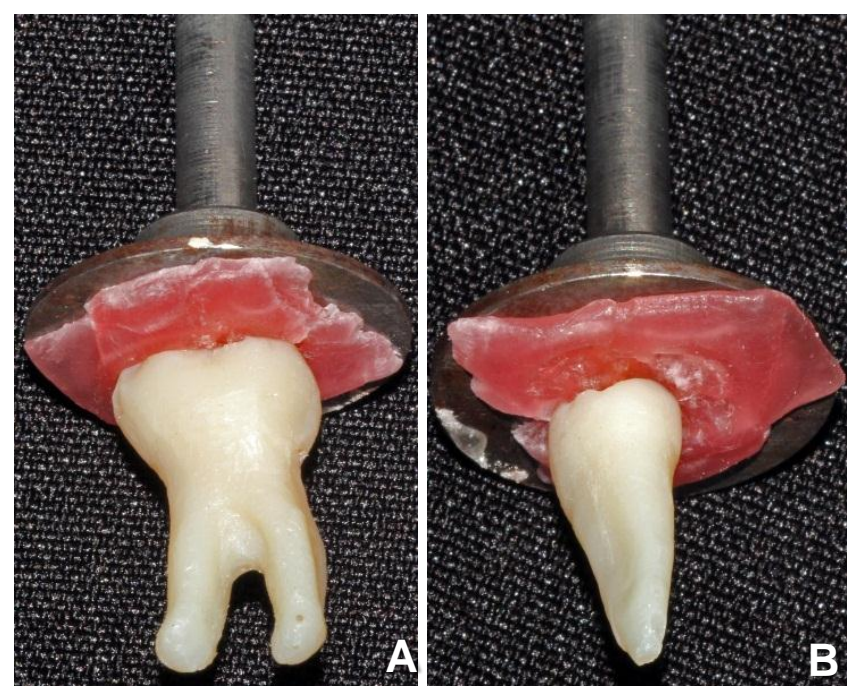

Figura 3 - Réplicas dentais fixadas à haste do paralelômetro: A) segundo molar inferior direito; B) segundo pré-molar inferior direito.
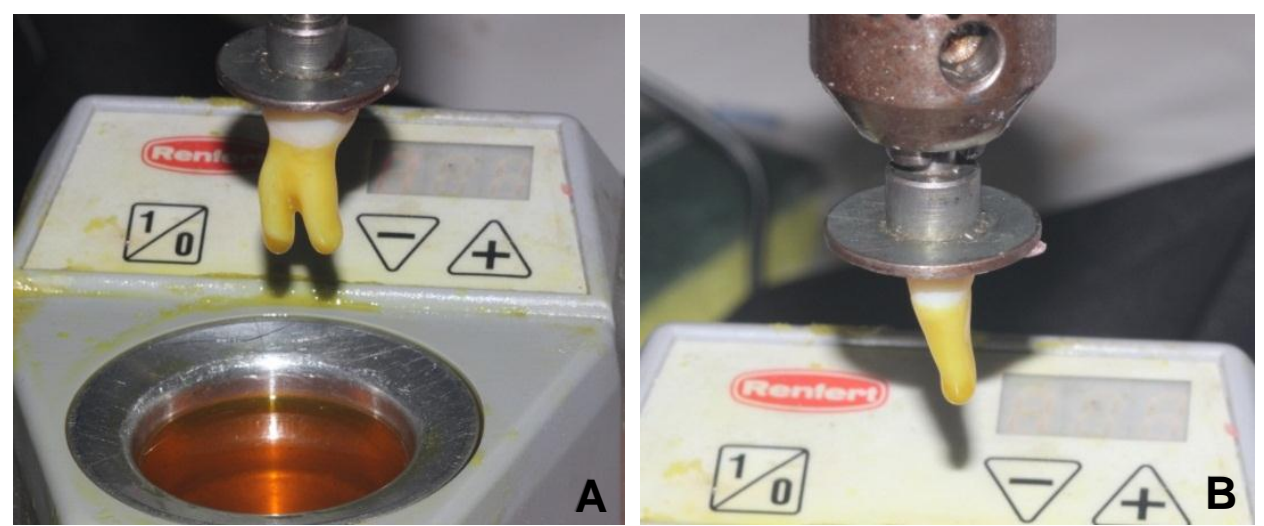

Figura 4 - Réplicas dentais removidas do plastificador com cera para escultura: A) segundo molar inferior direito; B) segundo pré-molar inferior direito. 


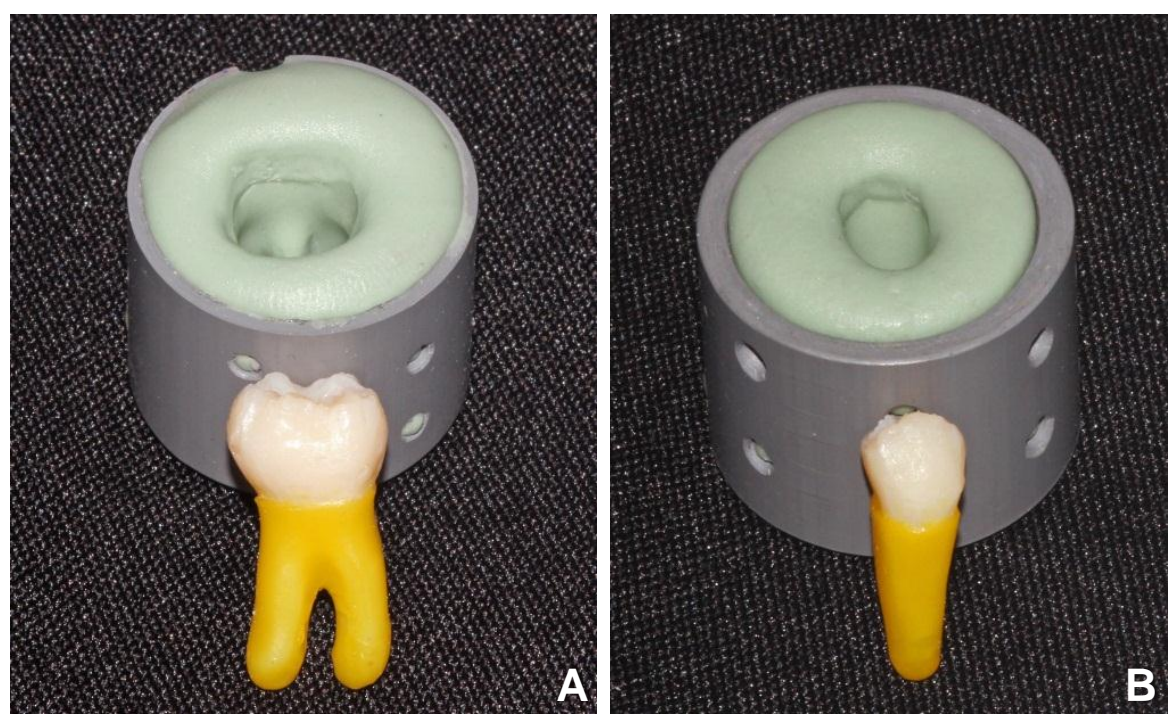

Figura 5 - Moldes para a simulação de ligamento periodontal nas réplicas dentais: A) segundo molar inferior direito; B) segundo pré-molar inferior direito.

Nos moldes foi injetado poliéter (Impregum Soft, 3M ESPE, Seefeld, Alemanha) e as réplicas dentais foram inseridas. Após a polimerização do material de moldagem, as réplicas foram removidas dos moldes (Figura 6). Os excessos de poliéter foram recortados e as superfícies das raízes avaliadas quanto à presença de bolhas e ausência de material.

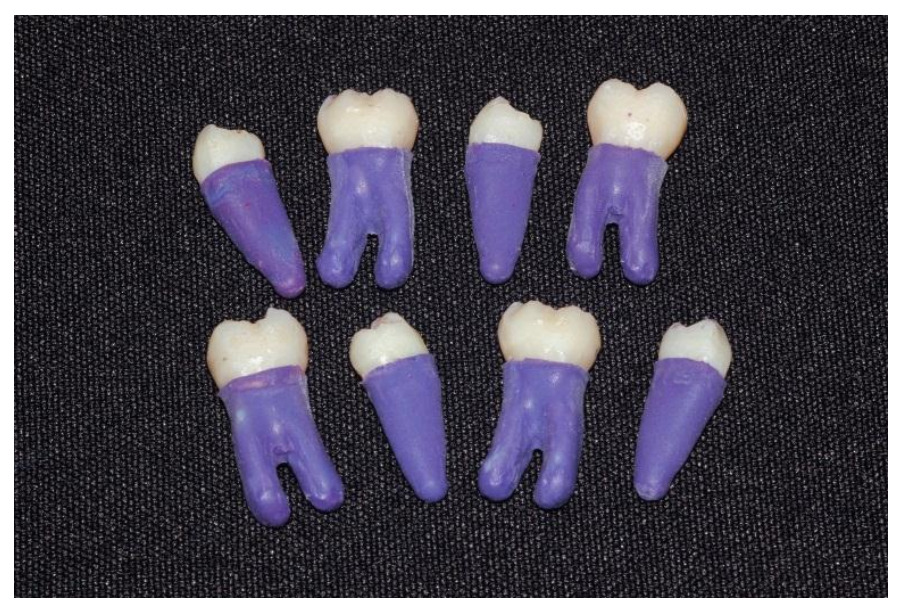

Figura 6 - Réplicas dentais com a simulação do ligamento periodontal. 


\subsection{Confecção das coroas protéticas}

Foram utilizadas para o presente estudo quatro coroas protéticas implantoretidas (Figura 7). Metade para a cimentação no pilar PP e o restante para a cimentação no pilar S. A opção por duas próteses para cada desenho de pilar teve como intuito manter permanentemente um exemplar no molde do modelo mestre e o outro usar somente para o carregamento dos modelos fotoelásticos. Cabe ressaltar que as coroas para o pilar PP foram provenientes de um estudo precursor (ALVES, 2013). Depois de avalia-las, chegou-se à conclusão que as condições estruturais das próteses permitiam que as mesmas fossem reutilizadas sem que representassem riscos aos resultados do estudo.

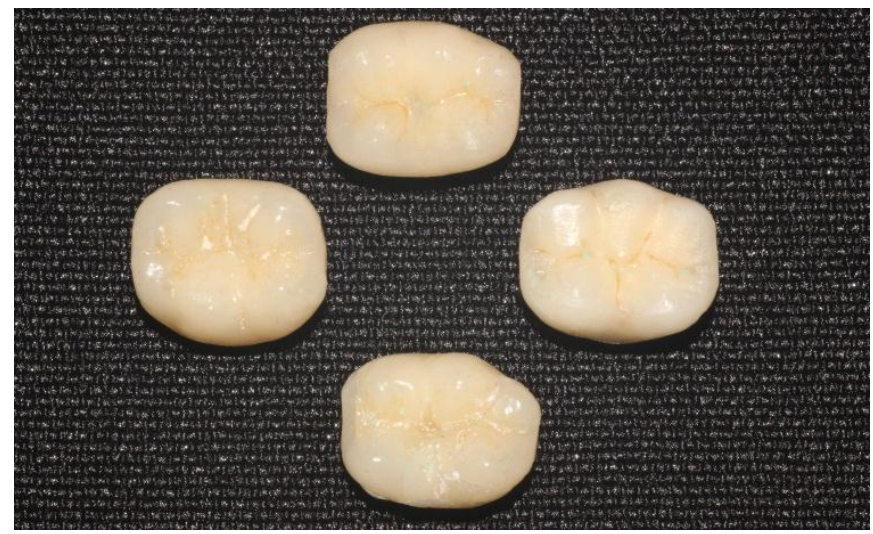

Figura 7 - Coroas protéticas dos pilares PP e S.

Sendo assim, houve a necessidade de confeccionar apenas as próteses para o pilar S. Para tanto, o pilar S com transmucoso de $1,5 \mathrm{~mm}$ foi inserido no modelo mestre (Figura 8). O modelo foi encaminhado logo em seguida ao laboratório de próteses dentárias (Domingos Facioli Prótese Odontológica S/S) designado pela pesquisa. O material selecionado para constituir a infraestrutura das coroas foi a zircônia (Figura 9). O recobrimento estético foi feito com a aplicação de cerâmica IPS Empress (Sistema CAD-CAM, Amanngirrbach, Áustria). 


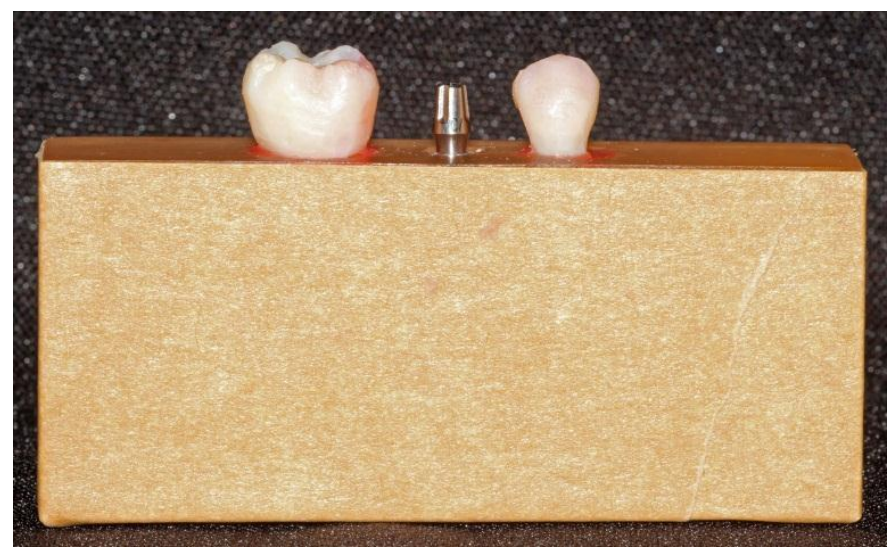

Figura 8 - Modelo mestre com o pilar protético $\mathrm{S}$ de transmucoso de $1,5 \mathrm{~mm}$.

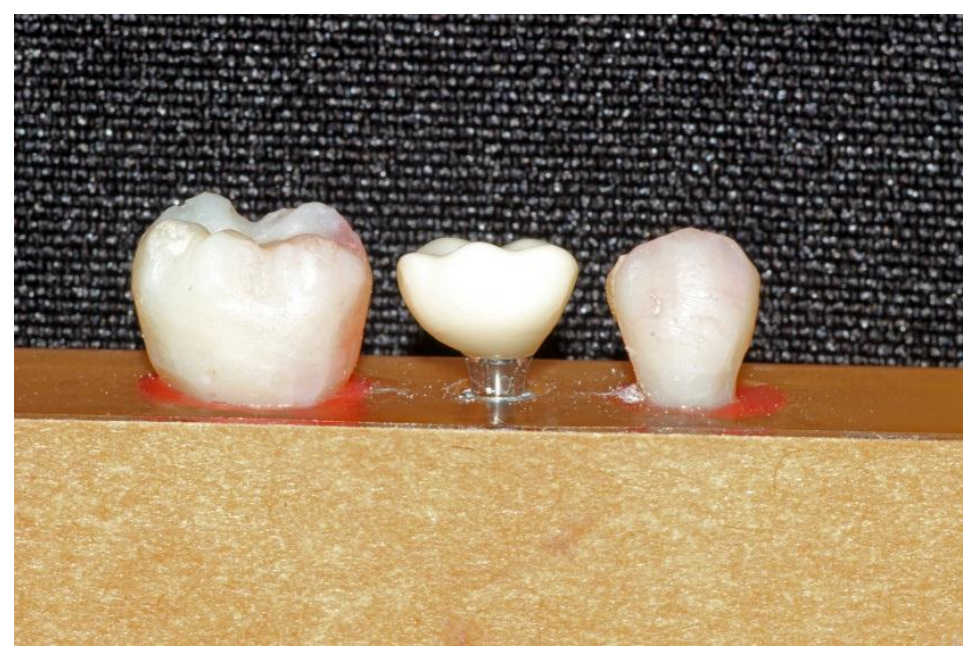

Figura 9 - Infraestrutura de zircônia.

O sistema CAD-CAM é composto pelo software Ceramill 3Shape e pela fresadora Ceramill Motion 2. As coroas produzidas apresentavam um padrão dimensional quando pertencentes ao mesmo desenho de pilar. Essa condição somente foi possível em virtude do gabarito plástico utilizado como referência. Apesar das coroas do pilar $S$ não terem sido obtidas no mesmo momento que as coroas do pilar PP, o método de confecção e o laboratório selecionado foram os mesmos. Ainda no laboratório, estando às coroas em posição no modelo mestre, as mesma foram avaliadas em relação aos pontos de contato proximal. Para analisalos, o técnico usou fio dental (Colgate-Palmolive, São Bernardo do Campo, São Paulo, Brasil) e papel carbono (AccuFilm II, Parkell, New York, EUA). Também foi averiguado se no sentido vestíbulo-lingual as coroas se mantinham proporcionais às réplicas dentais adjacentes. 


\subsection{Elaboração da ponta de carregamento}

O carregamento dos modelos fotoelásticos com réplicas dentais adjacentes ao implante foi através de uma ponta de carregamento personalizada (Figura $10 \mathrm{~A}$ ). Para elabora-la, dentes de estoque de pré-molares e molares superiores tiveram suas faces oclusais fixadas com cera 7 (Polidental Indústria e Comércio Ltda, Cotia, São Paulo, Brasil) nas faces oclusais das réplicas dentais do modelo mestre. A posição dos dentes de estoque em relação aos antagonistas foi definida segundo os contatos oclusais observados na dentição natural. Com uma lâmina de cera 7, uma muralha foi criada ao redor dos dentes de estoque. O anteparo permitiu que resina acrílica autopolimerizável (Artigos Odontológicos Clássico, Campo Limpo Paulista, São Paulo, Brasil) fluida fosse vertida e mantida sobre os dentes de estoque, sem extravasar para as faces vestibular e palatina. Após o término da polimerização, a cera foi eliminada com água aquecida e os dentes de estoque permaneceram no bloco de resina acrílica, caracterizando a hemi arcada antagonista do modelo mestre. Antes dos acabamentos uma haste metálica intercambiável foi fixada à ponta de carregamento. No caso dos modelos fotoelásticos que apresentavam apenas o implante, o carregamento foi realizado por intermédio de uma ponta metálica esférica (Figura 10 B) com diâmetro de $1 \mathrm{~mm}$.
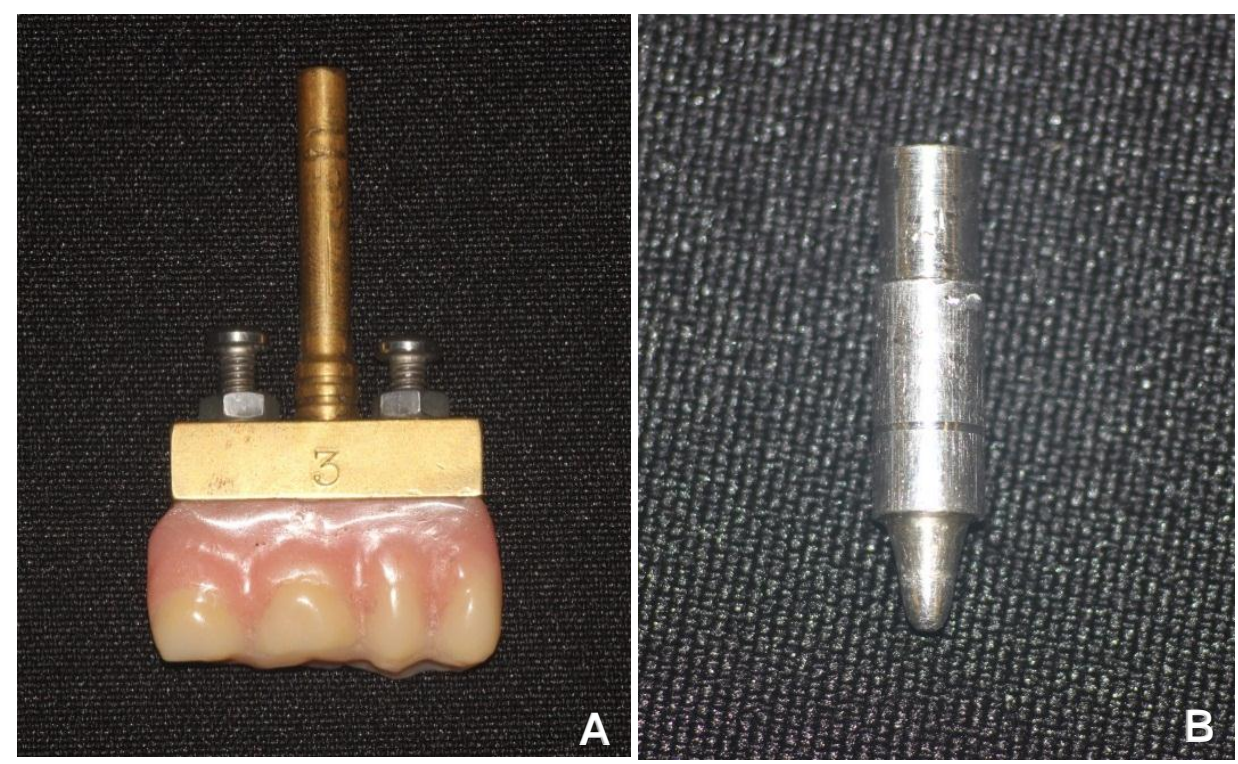

Figura 10 - Pontas de carregamento: A) personalizada; B) esférica. 


\subsection{Confecção dos modelos fotoelásticos}

Para obter os modelos fotoelásticos foi necessário confeccionar previamente moldes do modelo mestre em silicone de duplicação (Silicone Master, Talladium do Brasil, Curitiba, Paraná, Brasil). Um recipiente plástico e com tampa teve o fundo recortado (Figura $11 \mathrm{~A}$ ). Com o auxílio de uma fita adesiva dupla face (Adelbras, Vinhedo, São Paulo, Brasil) o modelo mestre foi fixado na porção interna da tampa, permanecendo as faces oclusais das réplicas dentais e da coroa protética voltadas para o fundo recortado (Figura 11B).

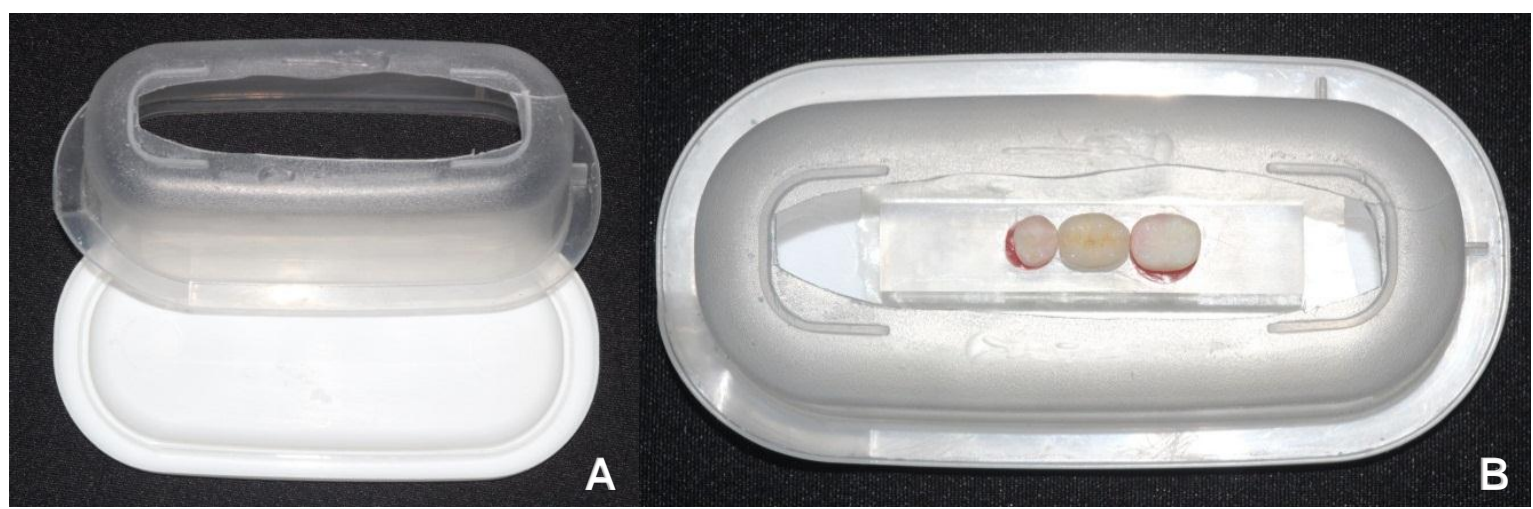

Figura 11 - Recipiente plástico: A) fundo recortado; B) modelo mestre em posição.

Em outro recipiente foi manipulado o material de moldagem seguindo a proporção de $200 \mathrm{ml}$ de silicone para $10 \mathrm{ml}$ de catalisador. Para atingir adequada homogeneização do produto foi necessário 60 segundos de manipulação. Ao fim, o silicone foi vertido vagarosamente pela abertura do recipiente, até preenchê-lo totalmente (Figura 12 A). Após 60 minutos o silicone se encontrava polimerizado, o que permitiu a abertura da tampa e a remoção do modelo mestre. Com a retirada do modelo a coroa protética permaneceu no interior do molde (Figura $12 \mathrm{~B}$ ). Os moldes do modelo mestre com o pilar PP foram os primeiros a serem confeccionados, logo depois foram os moldes do modelo mestre com o pilar S. O intuito de respeitar essa ordem foi evitar que a mudança de pilar entre as moldagens acarretasse alterações na posição de pilares de mesmo desenho nos modelos fotoelásticos. 


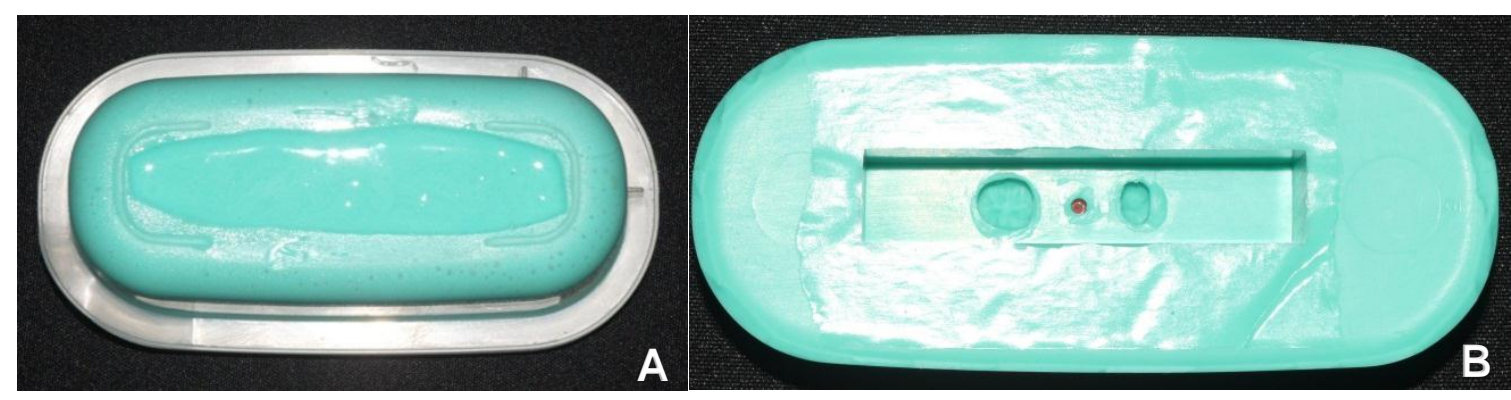

Figura 12 - Molde do modelo mestre: A) silicone fluido; B) coroa protética em posição.

Antes de obter o modelo fotoelástico, o pilar protético foi conectado ao implante. Para o pilar PP e S os torques de conexão usados foram de $15 \mathrm{Ncm}$ e 25 Ncm respectivamente. Na sequência o conjunto pilar/implante foi fixado à coroa do molde por meio de cera 7 na porção interna da prótese. Já as réplicas dentais se encaixaram no molde sem folgas, permanecendo estáveis (Figura 13).

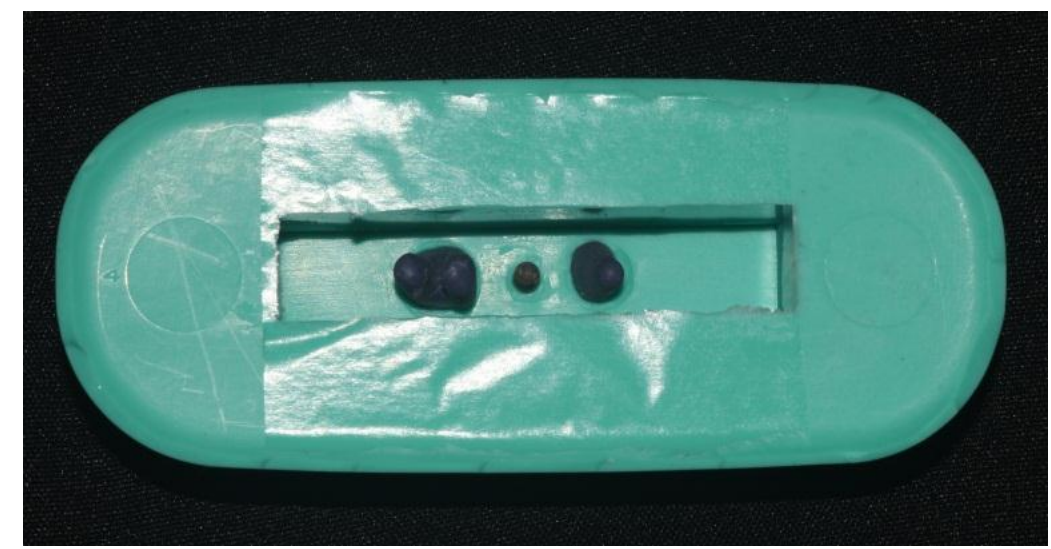

Figura 13 - Molde do modelo mestre com o conjunto pilar/implante e as réplicas dentais.

O material de confecção dos modelos fotoelásticos foi a resina Araldite GY279 e o endurecedor Aradur 2963 (Araltec - Produtos Químicos Ltda., Guarulhos, São Paulo, Brasil), na proporção de 2:1. As medidas foram determinadas em provetas e a manipulação da mistura em Becker, com o auxílio do bastão de vidro. Depois de dois minutos de manipulação, a mistura homogeneizada foi colocada por vinte minutos na câmara a vácuo, com o objetivo de eliminar bolhas de ar resultantes da manipulação. Em seguida o material foi lentamente inserido no molde, até preenchê-lo totalmente (Figura 14). As bolhas de ar que permaneceram no liquido já inserido foram removidas com sonda exploradora. Após 72 horas o modelo fotoelástico foi sacado e lavado com detergente neutro. A base foi lixada para remover irregularidades e simultaneamente aplaina-la. 


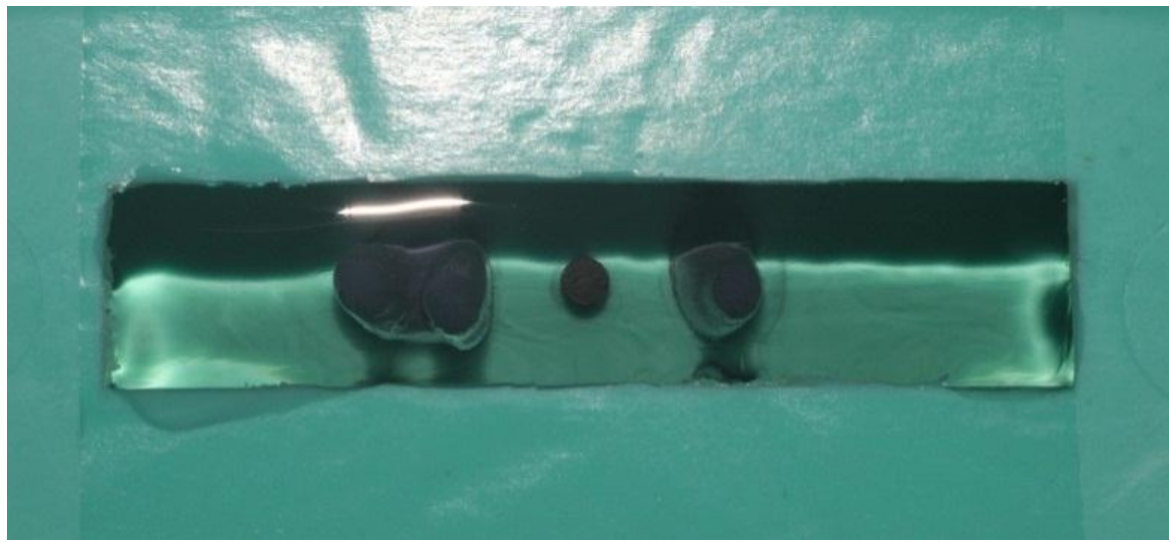

Figura 14 - Resina fotoelástica fluida no molde do modelo mestre.

A última etapa antes da análise fotoelástica foi a de ajuste oclusal e proximal da coroa protética e das réplicas dentais. Previamente à cimentação (Relyx Temp NE, 3M ESPE, Seefeld, Alemanha) da coroa, os contatos proximais foram avaliados com papel carbono e fio dental. Para o ajuste oclusal a ponta de carregamento foi colocada no paralelômetro, permanecendo logo acima do modelo fotoelástico. Repetidos toques entre os dentes antagonistas interpostos por papel carbono identificaram áreas com contato oclusal prematuro, as quais foram ajustadas com fresas em baixa rotação. Quando necessária, a resina acrílica autopolimerizável foi acrescentada na face oclusal dos dentes de estoque da ponta de carregamento, a fim de obter contatos oclusais efetivos e distribuídos.

\subsection{Análise Fotoelástica}

O método de análise fotoelástica selecionado permitiu que resultados quantitativos fossem obtidos a cerca da distribuição de tensão nos modelos fotoelásticos submetidos a carregamento de $200 \mathrm{Ncm}$. Antes das leituras, os modelos fotoelásticos receberam marcações na porção frontal, correspondentes a pontos de interesse quanto à incidência de tensão (Figura 15). A escolha dos pontos determinou uma sequência numérica de 1 a 9 . Nos modelos fotoelásticos com implante adjacente ao segundo pré-molar inferior e ao segundo molar inferior havia todos os pontos, os modelos com implante adjacente ao segundo pré-molar inferior apresentavam os pontos de 1 a 7 e os modelos com implante isolado continham os pontos de 3 a 7. 


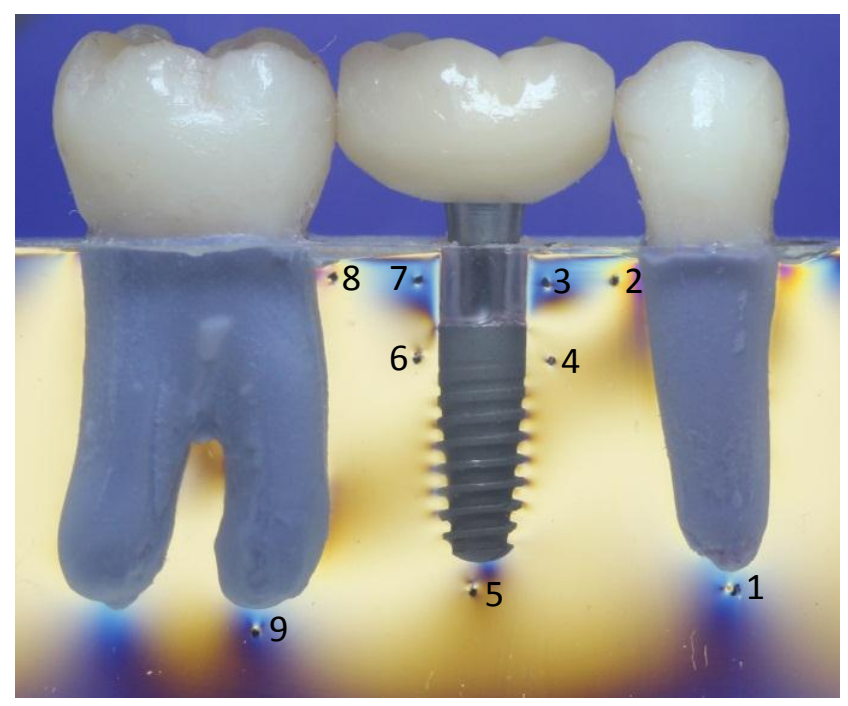

Figura 15 - Pontos de interesse quanto à incidência de tensão.

Os pontos permaneceram afastados $1 \mathrm{~mm}$ dos implantes e das réplicas dentais, concomitantemente ocuparam posições específicas em relação à crista óssea, ao ápice dos dentes e dos implantes e à plataforma dos implantes, conforme a descrição presente na tabela 2. Cabe ressaltar que os números dos pontos corresponderam às mesmas localizações nos diferentes modelos fotoelásticos e que para os implantes equicristais os pontos 3 e 4, assim como os pontos 6 e 7 foram coincidentes.

Tabela 2 - Descrição dos pontos de 1 a 9 segundo a localização.

\begin{tabular}{cc}
\hline Ponto & Descrição da Localização \\
\hline 1 & $1 \mathrm{~mm}$ abaixo do ápice do segundo pré-molar \\
2 & $1 \mathrm{~mm}$ abaixo da crista óssea distal do segundo pré-molar \\
3 & $1 \mathrm{~mm}$ abaixo da plataforma do implante na mesial \\
4 & $1 \mathrm{~mm}$ abaixo do ápice do implante \\
5 & $1 \mathrm{~mm}$ abaixo da plataforma do implante na distal \\
6 & $1 \mathrm{~mm}$ abaixo da crista óssea distal do implante \\
7 & $1 \mathrm{~mm}$ abaixo da crista óssea mesial do segundo molar \\
8 & $1 \mathrm{~mm}$ abaixo do ápice da raiz mesial do segundo molar \\
9
\end{tabular}

Para marcar os pontos no modelo fotoelástico foi utilizado um projetor de perfil e uma grade de pontos. Os pontos foram registrados na superfície do modelo 
com agulha hipodérmica descartável e posteriormente retocados com caneta esferográfica, a fim de facilitar a visualização durante a leitura. Uma vez delimitados os pontos, o modelo fotoelástico foi levado à estufa a $50^{\circ} \mathrm{C}$ por 10 minutos. Em seguida permaneceu pelo mesmo tempo a $22^{\circ} \mathrm{C}$ para resfriar. $\mathrm{O}$ procedimento visava à eliminação de tensões provenientes de ajustes prévios no modelo. Antes da aplicação da carga, o modelo foi avaliado no equipamento fotoelástico quanto à presença de tensões residuais. Quando confirmadas, os contatos proximais foram novamente ajustados e o modelo levado mais uma vez à estufa pelo mesmo período designado anteriormente.

O polariscópio (PS-100 Polarimeter Systems / Strainoptics, Inc., North Wales, EUA) (Figura 16) selecionado para as análises fotoelásticas do presente estudo conta com um dispositivo composto por uma célula de carga de 50 Kgf (Kratos, São Paulo, Brasil), um leitor de carga (IKE-01, Kratos) e pontas de carregamento. O polariscópio em questão possibilitou que uma máquina fotográfica digital (EOS Rebel, Canon, Tóquio, Japão) fosse acoplada, com o intuito de registrar a distribuição de tensão.

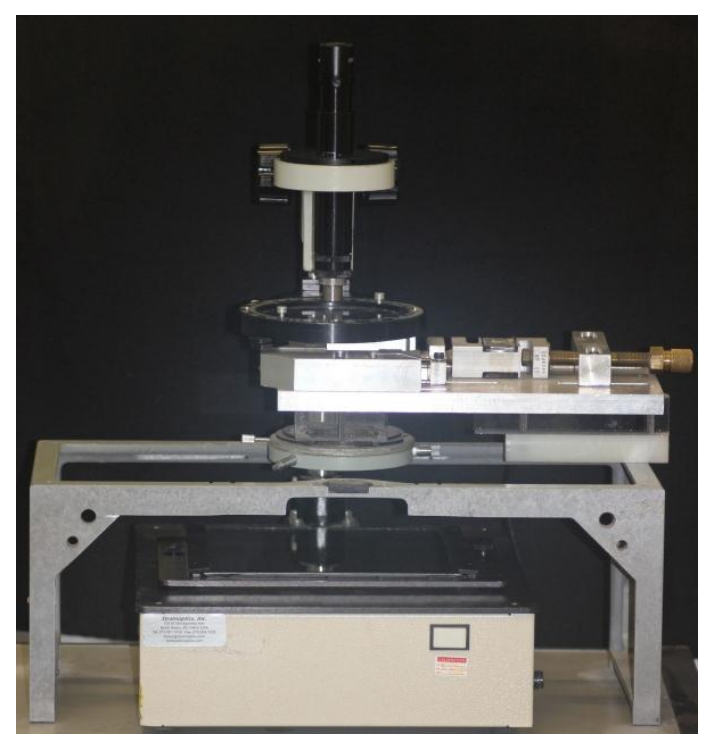

Figura 16 - Polariscópio.

Estando o polariscópio no modo de polarização plana e usando uma lente de aumento de $10 \times$ (Nikon, Tóquio, Japão) foi possível analisar os modelos fotoelásticos segundo critérios quantitativos. Para a determinação de ordem de franja $(n)$ se empregou o método de Senarmont (MONTAROU e GAYLORD, 2004). 
O qual se baseia no uso de uma lupa com ampliação de 10X, constituída por um filtro isocromático que somente permite a visualização de cores preta e amarela. A coloração preta se remete às franjas isoclínicas, a amarela à área de transição entre as franjas.

Com o alinhamento dos filtros polarizadores e com a interposição do modelo fotoelástico entre os mesmos o ponto desejado foi identificado. Primeiramente foi definido entre quais ordens de franja ele estava. Na sequência o suporte contendo o modelo foi rotacionado em sentido horário, até que o ponto ficasse totalmente escuro em virtude da sobreposição de uma franja isoclínica. A rotação do suporte é definida em graus com base em marcações pré-existentes. O suporte foi rotacionado novamente seguindo o mesmo sentido. Contudo, com um acréscimo estabelecido em $45^{\circ}$ a partir de sua última posição. O ponto que anteriormente se encontrava escuro se tornou claro.

Em seguida, o disco analisador com as frações de ordens de franja $(0,0$ a 1,0 n) foi rotacionado no sentido horário, até que surgisse uma franja isoclínica que passasse pelo ponto, escurecendo-o mais uma vez. O movimento permitiu averiguar qual a franja que se aproximou do ponto à medida que ocorria o escurecimento. Estando o ponto entre duas ordens de franja havia duas possibilidades de calcula-la. Quando da aproximação da franja de maior ordem, a fração obtida com o disco analisador foi subtraída do valor da franja. Quando foi a franja de menor ordem que se aproximou, a fração registrada com o disco analisador foi somada ao valor da franja.

Uma vez finalizadas as leituras foi determinada a tensão incidente em cada ponto. Para tanto se utilizou a equação da lei óptica das tensões (E1), na qual b (14 $\mathrm{mm}$ ) corresponde à espessura do modelo fotoelástico, $\mathrm{K}$ (3,65 Brewsters) se refere à constante óptica da resina Araldite GY279 (AGUIAR JR, 2009), n o valor da ordem de franja do ponto e $\lambda(570 \mathrm{~nm})$ o comprimento de ondas dos materiais plásticos.

Equação da lei óptica das tensões:

$$
\sigma=\frac{n \cdot \lambda}{b \cdot K}=\frac{n \cdot 570}{14 \cdot 3,65}
$$


5.RESULTADOS 
Os resultados são apresentados considerando as distintas situações propostas, implante adjacente ao segundo pré-molar inferior e ao segundo molar inferior, implante adjacente ao segundo pré-molar inferior e implante isolado. Em cada ponto, para cada situação houve a comparação das tensões geradas nos modelos fotoelásticos com pilares PP e $S$ de mesma altura de transmucoso. Paralelamente, a distribuição de tensão foi avaliada com base na profundidade do implante na crista óssea, para tanto foram comparados os valores de tensão de modelos fotoelásticos com pilares de mesmo desenho, porém com diferentes alturas de transmucoso. O estudo foi estruturado segundo uma análise quantitativa, a qual teve os valores descritos em MPa. Na maioria das comparações realizadas foram encontradas diferenças na distribuição de tensão. Quando a diferença foi menor ou igual a $10 \%$, as tensões foram consideradas iguais.

\subsection{Implante adjacente ao segundo pré-molar inferior e ao segundo molar inferior}

\subsubsection{Transmucoso de 1,5 mm (comparação entre pilar PP e S)}

As figuras 17 e 18 e a tabela 3 apresentam os resultados obtidos a partir do carregamento dos modelos com pilar PP e $S$ com transmucoso de 1,5 mm. As tensões observadas nos pontos 1, 3, 4, 6, 7 e 8 foram maiores no modelo com pilar PP. Nos pontos 2 e 5 as maiores tensões estiveram no modelo com pilar S. Em 9 houve uma condição de valores iguais entre os pilares. O pilar PP proporcionou $52 \%$ e $76 \%$ mais tensão na crista óssea peri-implantar distal e mesial respectivamente. $\mathrm{Na}$ crista óssea adjacente ao segundo pré-molar, o pilar PP gerou tensão 68\% menor. Porém, na crista óssea adjacente ao segundo molar o pilar S proporcionou $74 \%$ menos tensão. No ápice do implante a tensão encontrada foi $14 \%$ superior com o pilar S. 


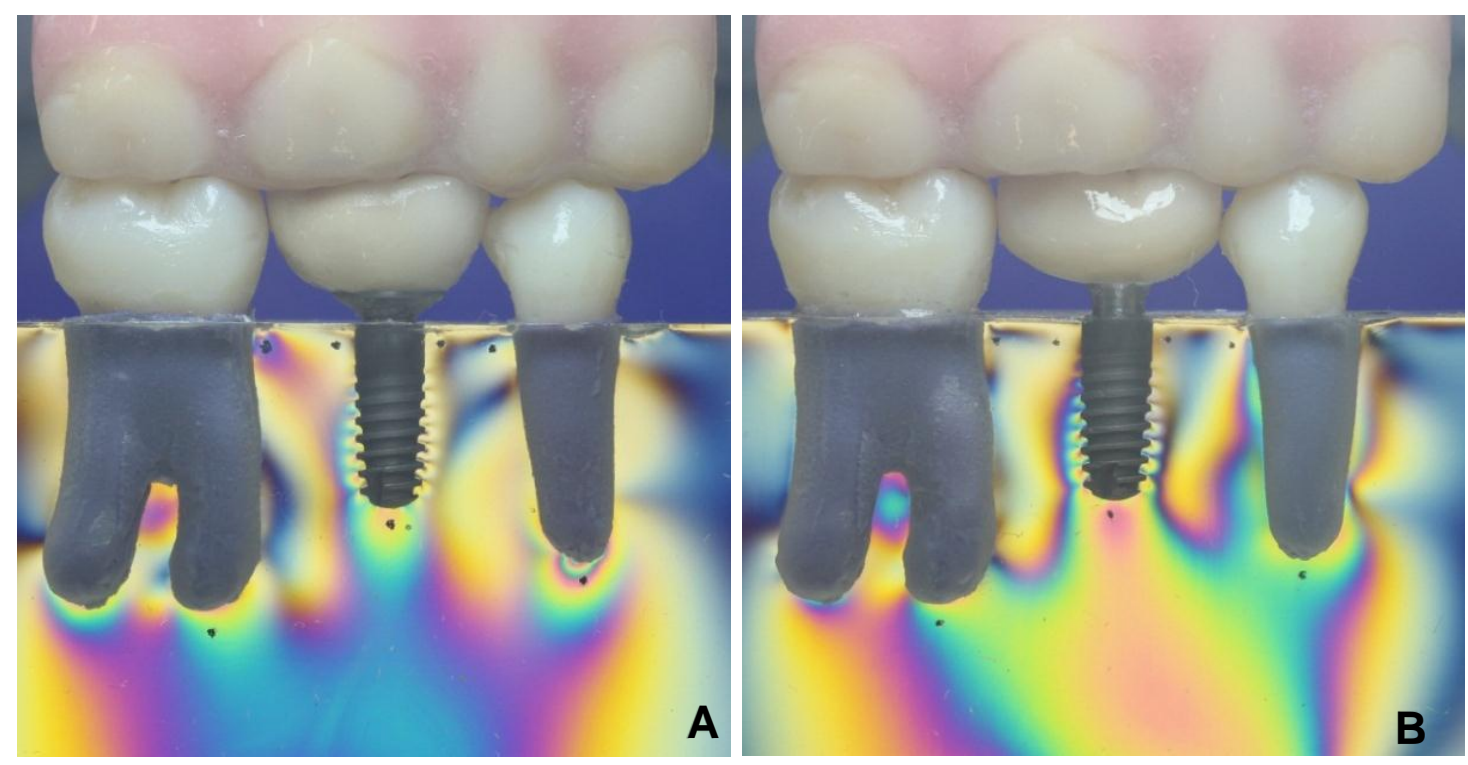

Figura 17 - Imagens fotoelásticas: A) pilar PP com transmucoso de 1,5 mm; B) pilar S com transmucoso de $1,5 \mathrm{~mm}$.

Tabela 3 - Tensões incidentes nos pontos de 1 a 9 dos modelos fotoelásticos com pilar PP e S de transmucoso de $1,5 \mathrm{~mm}$.

\begin{tabular}{ccc}
\hline \multirow{2}{*}{ Ponto } & \multicolumn{2}{c}{ Tensão (MPa) } \\
\cline { 2 - 3 } & PP 1,5 & S 1,5 \\
\hline $\mathbf{1}$ & 22,87 & 13,94 \\
$\mathbf{2}$ & 1,45 & 4,46 \\
$\mathbf{3}$ & 4,57 & 1,12 \\
$\mathbf{4}$ & 4,57 & 1,12 \\
$\mathbf{5}$ & 17,85 & 20,86 \\
$\mathbf{6}$ & 7,36 & 3,57 \\
$\mathbf{7}$ & 7,36 & 3,57 \\
$\mathbf{8}$ & 9,82 & 2,57 \\
$\mathbf{9}$ & 14,61 & 14,95 \\
\hline
\end{tabular}




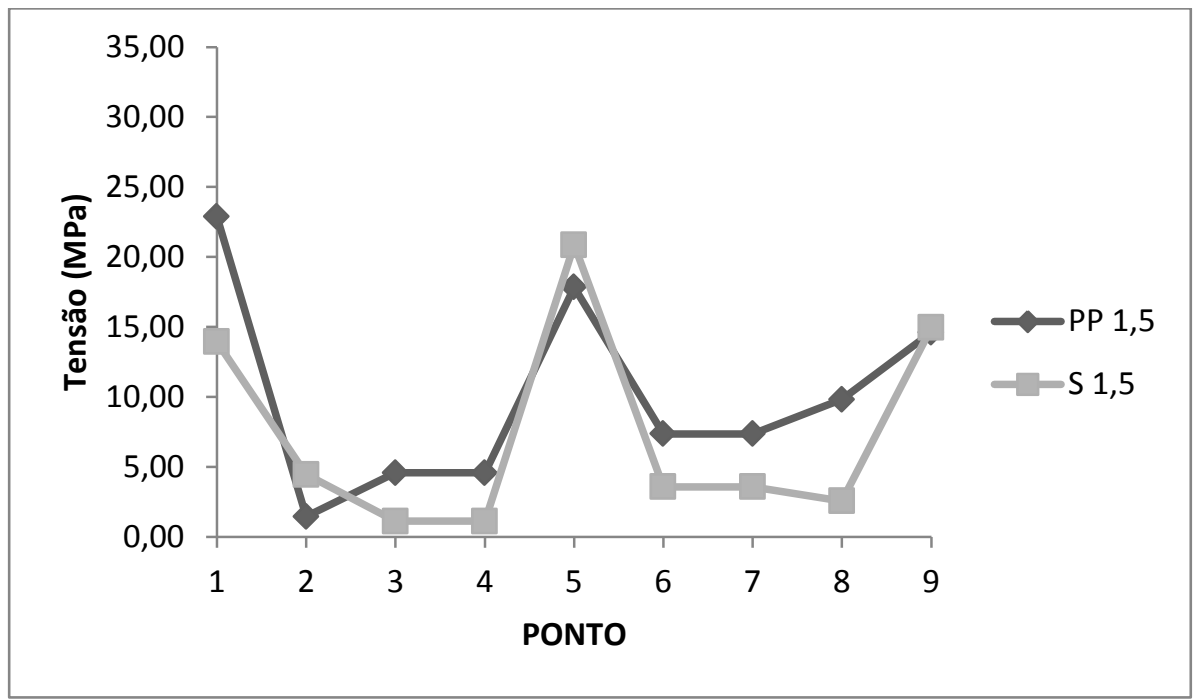

Figura 18 - Gráfico das tensões em cada ponto analisado no carregamento oclusal distribuído - PP 1,5: pilar de parafuso passante e transmucoso de 1,5 mm; S 1,5: pilar sólido e transmucoso de 1,5 mm.

\subsubsection{Transmucoso de 3,0 mm (comparação entre pilar PP e S)}

As figuras 19 e 20 e a tabela 4 apresentam os resultados obtidos a partir do carregamento dos modelos com pilar PP e $S$ com transmucoso de 3,0 mm. Nos pontos 1, 3, 6, 7 e 8 as maiores tensões estiveram no modelo com pilar PP. No ponto 2 a maior tensão foi no modelo com pilar S. Nos demais pontos, 4, 5 e 9 as tensões foram iguais entre os pontos de mesma numeração. Na crista óssea periimplantar mesial e distal, o pilar PP aumentou as tensões em $14 \%$ e $38 \%$ respectivamente. Com o pilar $\mathrm{S}$ a crista óssea adjacente ao segundo molar recebeu uma tensão $68 \%$ menor. O pilar PP diminuiu em $74 \%$ a tensão gerada na crista óssea adjacente ao segundo pré-molar. 

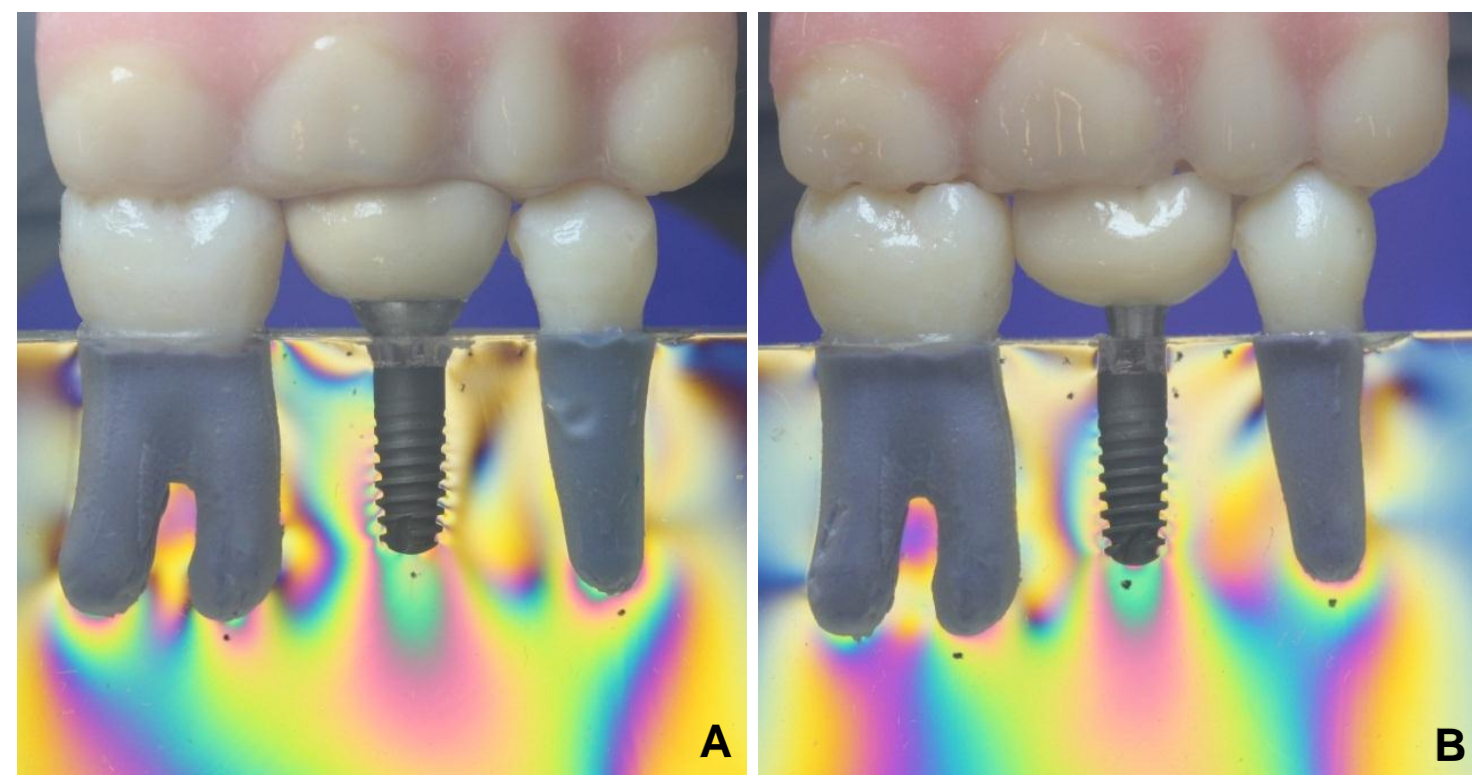

A

Figura 19 - Imagens fotoelásticas: A) pilar PP com transmucoso de 3,0 mm; B) pilar S com transmucoso de $3,0 \mathrm{~mm}$.

Tabela 4 - Tensões incidentes nos pontos de 1 a 9 dos modelos fotoelásticos com pilar PP e $S$ de transmucoso de $3,0 \mathrm{~mm}$.

\begin{tabular}{ccc}
\hline \multirow{2}{*}{ Ponto } & \multicolumn{2}{c}{ Tensão $(\mathrm{MPa})$} \\
\cline { 2 - 3 } & PP 3,0 & S 3,0 \\
\hline $\mathbf{1}$ & 18,74 & 15,84 \\
$\mathbf{2}$ & 1,45 & 5,58 \\
$\mathbf{3}$ & 4,46 & 3,90 \\
$\mathbf{4}$ & 3,46 & 3,79 \\
$\mathbf{5}$ & 28,33 & 27,89 \\
$\mathbf{6}$ & 14,05 & 8,59 \\
$\mathbf{7}$ & 3,23 & 2,34 \\
$\mathbf{8}$ & 13,50 & 4,35 \\
$\mathbf{9}$ & 19,30 & 17,96 \\
\hline
\end{tabular}




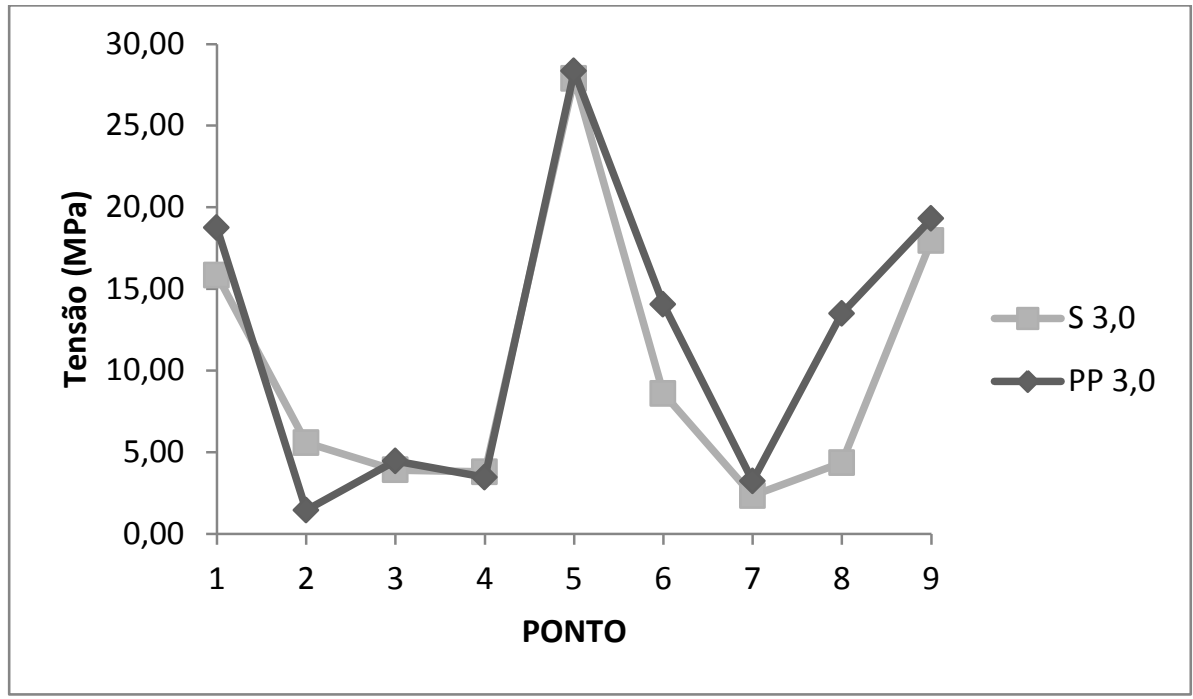

Figura 20 - Gráfico das tensões em cada ponto analisado no carregamento oclusal distribuído - PP 3,0: pilar de parafuso passante e transmucoso de 3,0 mm; S 3,0: pilar sólido e transmucoso de 3,0 mm.

\subsubsection{Transmucoso de 4,5 mm (comparação entre pilar PP e S)}

As figuras 21 e 22 e a tabela 5 apresentam os resultados obtidos a partir do carregamento dos modelos com pilar PP e $S$ com transmucoso de 4,5 mm. Nos pontos 1, 2, 3, 6, e 8 as maiores tensões estiveram no modelo com pilar PP. Nos pontos 4 e 5 as maiores tensões foram no modelo com pilar S. Em 7 e 9 as tensões foram iguais entre os pontos de mesma numeração. No ápice do implante a tensão induzida pelo pilar S foi $16 \%$ maior. Na crista óssea peri-implantar mesial, o pilar S gerou uma redução de tensão em $71 \%$, condição semelhante à encontrada nas cristas ósseas adjacentes ao segundo pré-molar e ao segundo molar, com redução de tensão em $45 \%$ e $20 \%$ respectivamente. 

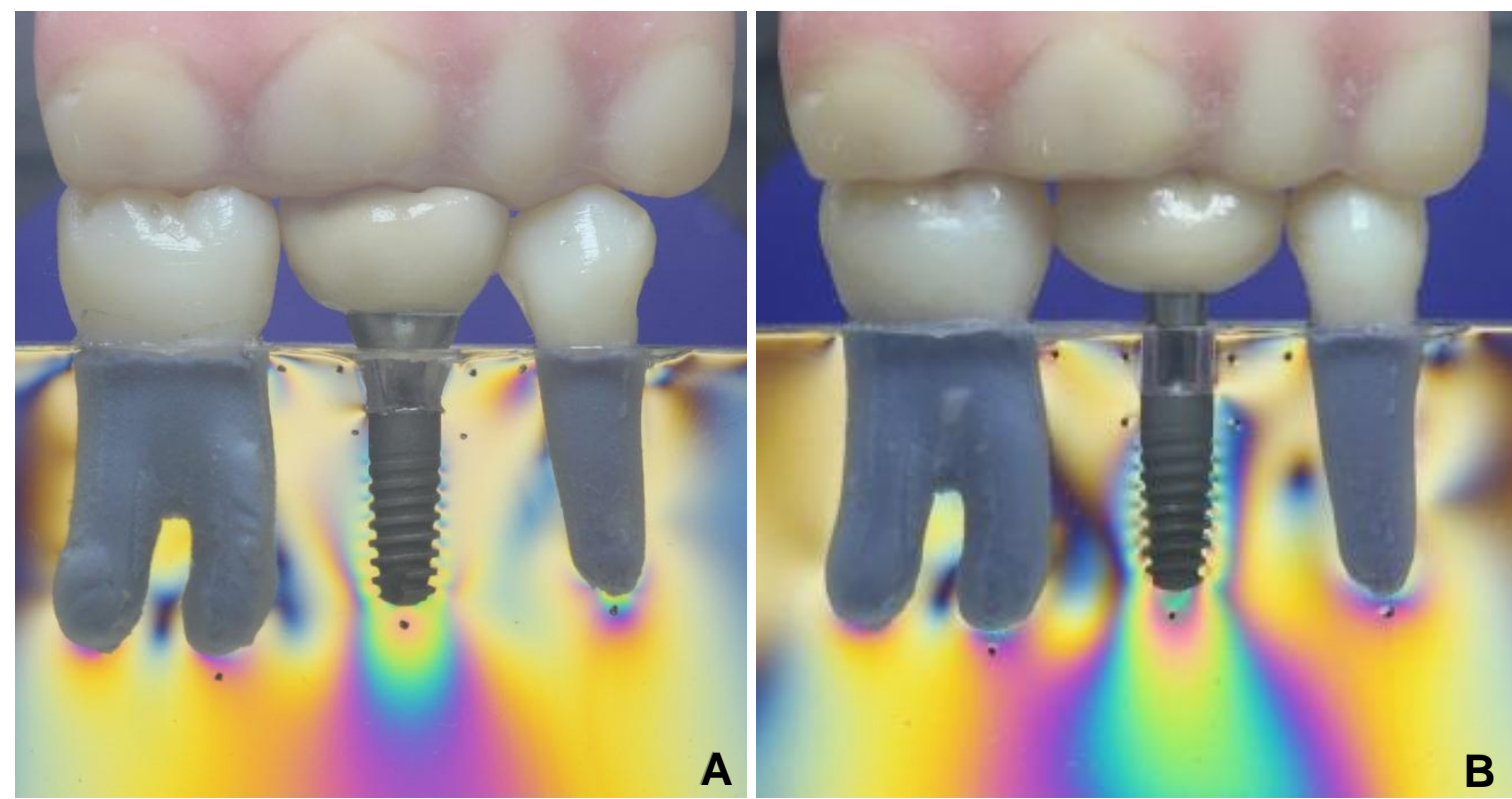

Figura 21 - Imagens fotoelásticas: A) pilar PP com transmucoso de 4,5 mm; B) pilar S com transmucoso de $4,5 \mathrm{~mm}$.

Tabela 5 - Tensões incidentes nos pontos de 1 a 9 dos modelos fotoelásticos com pilar PP e S de transmucoso de $4,5 \mathrm{~mm}$.

\begin{tabular}{ccc}
\hline \multirow{2}{*}{ Ponto } & \multicolumn{2}{c}{ Tensão (MPa) } \\
\cline { 2 - 3 } & PP 4,5 & $\mathbf{S ~ 4 , 5}$ \\
\hline $\mathbf{1}$ & 12,60 & 10,49 \\
$\mathbf{3}$ & 7,92 & 5,47 \\
$\mathbf{4}$ & 3,23 & 1,90 \\
$\mathbf{5}$ & 7,59 & 13,27 \\
$\mathbf{6}$ & 20,52 & 24,54 \\
$\mathbf{7}$ & 7,70 & 6,25 \\
$\mathbf{8}$ & 1,78 & 1,78 \\
$\mathbf{9}$ & 8,70 & 7,25 \\
\hline
\end{tabular}




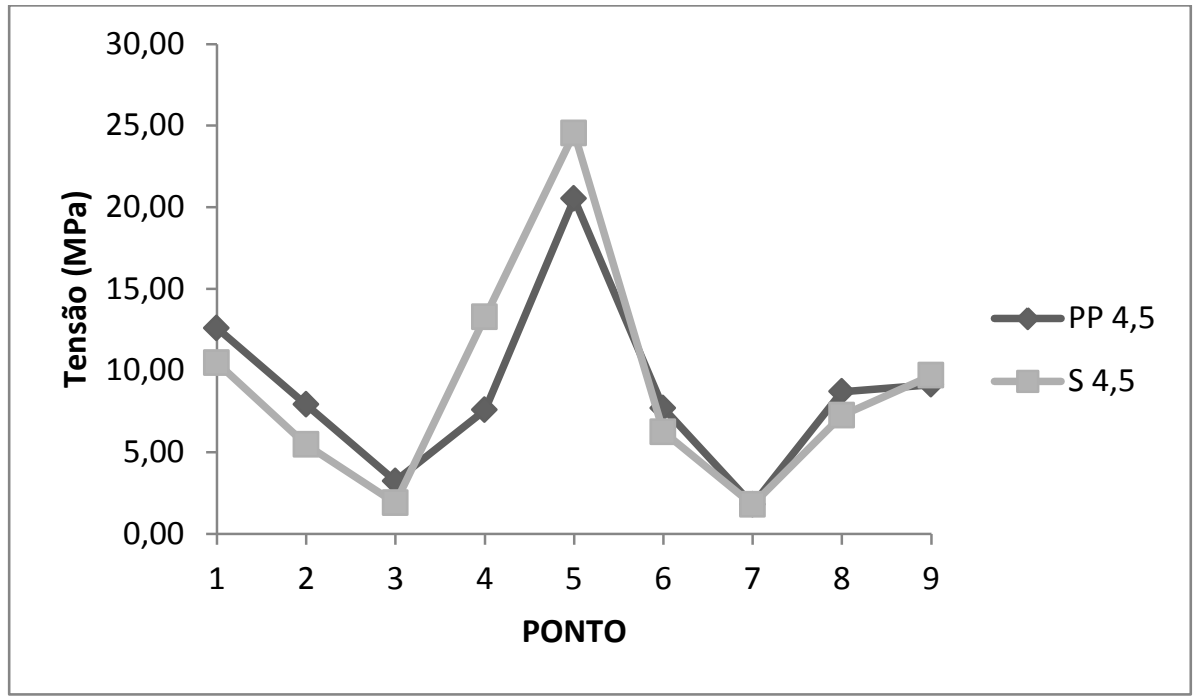

Figura 22 - Gráfico das tensões em cada ponto analisado no carregamento oclusal distribuído - PP 4,5: pilar de parafuso passante e transmucoso de 4,5 mm; S 4,5: pilar sólido e transmucoso de 4,5 mm.

\subsubsection{Pilar PP (transmucoso de $1,5 \mathrm{~mm}, 3,0 \mathrm{~mm}$ e $4,5 \mathrm{~mm}$ )}

A tabela 6 e a figura 23 apresentam os resultados obtidos a partir do carregamento dos modelos com pilar PP com alturas de transmucoso de 1,5 mm, $3,0 \mathrm{~mm}$ e 4,5 mm. Neste caso o desenho do pilar protético foi o mesmo, o que variou foi a altura do transmucoso. Desta forma, os resultados consideram a profundidade do implante na crista óssea. Nos pontos 1 e 7 as maiores tensões estiveram no modelo com implante equicristal. Em 2 e 4 as maiores tensões foram no modelo com implante infraósseo a 3,0 mm. Os pontos 3, 5, 6, 8 e 9 receberam maiores tensões no modelo com implante infraósseo a $1,5 \mathrm{~mm}$, sendo que no ponto 3 a tensão foi igual a do modelo com implante equicristal. Na crista óssea peri-implantar mesial, o implante infraósseo a 3,0 mm reduziu a tensão em $41 \%$. Na crista óssea periimplantar distal os implantes infraósseo a 1,5 $\mathrm{mm}$ e a 3,0 $\mathrm{mm}$ reduziram as tensões em $56 \%$ e $76 \%$ respectivamente. No ápice do implante, os implantes equicristal e infraósseo a 3,0 mm reduziram as tensões em $59 \%$ e $38 \%$ respectivamente. A crista óssea adjacente ao segundo pré-molar recebeu tensões $82 \%$ menores quando implantes equicristal e infraósseo a 1,5 mm foram utilizados. A escolha por implantes equicristal e infraósseo a 3,0 mm reduziu as tensões na crista óssea adjacente ao segundo molar em $27 \%$ e $55 \%$ respectivamente. 
Tabela 6 - Tensões incidentes nos pontos de 1 a 9 dos modelos fotoelásticos com pilar PP de transmucoso de 1,5 mm, 3,0 $\mathrm{mm}$ e 4,5 mm.

\begin{tabular}{cccc}
\hline \multirow{2}{*}{ Ponto } & \multicolumn{3}{c}{ Tensão (MPa) } \\
\cline { 2 - 4 } & PP 1,5 & PP 3,0 & PP 4,5 \\
\hline $\mathbf{1}$ & 22,87 & 18,74 & 12,60 \\
$\mathbf{2}$ & 1,45 & 1,45 & 7,92 \\
$\mathbf{3}$ & 4,57 & 4,46 & 3,23 \\
$\mathbf{4}$ & 4,57 & 3,46 & 7,59 \\
$\mathbf{5}$ & 17,85 & 28,33 & 20,52 \\
$\mathbf{6}$ & 7,36 & 14,05 & 7,70 \\
$\mathbf{7}$ & 7,36 & 3,23 & 1,78 \\
$\mathbf{8}$ & 9,82 & 13,50 & 8,70 \\
$\mathbf{9}$ & 14,61 & 19,30 & 9,15 \\
\hline
\end{tabular}

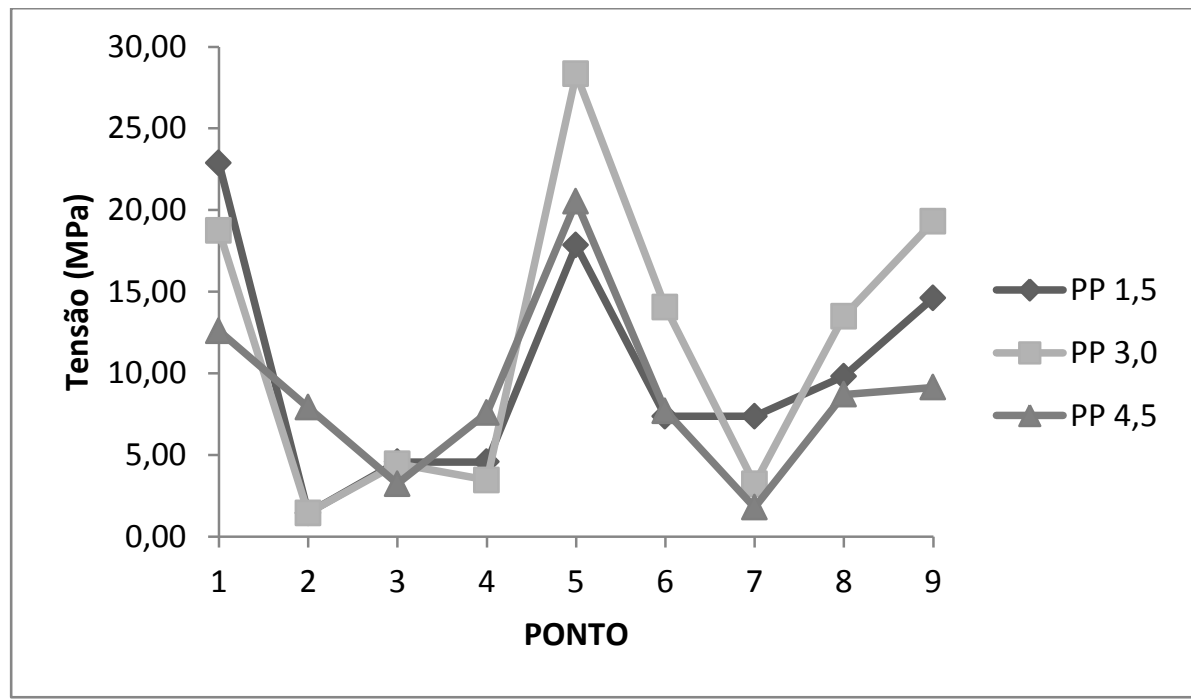

Figura 23 - Gráfico das tensões em cada ponto analisado no carregamento oclusal distribuído - PP 1,5: pilar de parafuso passante e transmucoso de 1,5 mm; PP 3,0: pilar de parafuso passante e transmucoso de 3,0 mm; PP 4,5: pilar de parafuso passante e transmucoso de $4,5 \mathrm{~mm}$.

\subsubsection{Pilar S (transmucoso de 1,5 mm, 3,0 mm e 4,5 mm)}

A tabela 7 e a figura 24 apresentam os resultados obtidos a partir do carregamento dos modelos com pilar $\mathrm{S}$ com alturas de transmucoso de $1,5 \mathrm{~mm}, 3,0$ $\mathrm{mm}$ e 4,5 mm. Nos pontos 1, 3, 5, 6 e 9 as maiores tensões estiveram no modelo com implante infraósseo a $1,5 \mathrm{~mm}$. No ponto 2 as maiores tensões foram nos modelos com implantes infraósseo, sendo os valores iguais. Em 4 e 8 as tensões mais altas foram no modelo com implante infraósseo a 3,0 $\mathrm{mm}$. No ponto 7 a maior tensão esteve no modelo com implante equicristal. Na crista óssea peri-implantar mesial, reduções de tensões foram vistas com os implantes equicristal e infraósseo a 
3,0 $\mathrm{mm}$, correspondendo a $71 \%$ e $51 \%$ respectivamente. Na crista óssea periimplantar distal, o implante infraósseo a 1,5 mm reduziu a tensão em 34\%, enquanto que com o implante infraósseo a $3,0 \mathrm{~mm}$ a redução foi de $50 \%$. No ápice do implante, os implantes equicristal e infraósseo a 3,0 mm diminuíram as tensões em $25 \%$ e $12 \%$ respectivamente. Com relação à crista óssea adjacente ao segundo prémolar foi observado que o posicionamento equicristal do implante reduziu em $20 \%$ a tensão. Na crista óssea adjacente ao segundo molar, os implantes equicristal e infraósseo a 1,5 mm diminuíram as tensões em 65\% e 40\% respectivamente.

Tabela 7 - Tensões incidentes nos pontos de 1 a 9 dos modelos fotoelásticos com pilar $S$ de transmucoso de $1,5 \mathrm{~mm}, 3,0 \mathrm{~mm}$ e $4,5 \mathrm{~mm}$.

\begin{tabular}{cccc}
\hline \multirow{2}{*}{ Ponto } & \multicolumn{3}{c}{ Tensão (MPa) } \\
\cline { 2 - 4 } & $\mathbf{S ~ 1 , 5}$ & $\mathbf{S ~ 3 , 0}$ & $\mathbf{S ~ 4 , 5}$ \\
\hline $\mathbf{1}$ & 13,94 & 15,84 & 10,49 \\
$\mathbf{2}$ & 4,46 & 5,58 & 5,47 \\
$\mathbf{3}$ & 1,12 & 3,90 & 1,90 \\
$\mathbf{4}$ & 1,12 & 3,79 & 13,27 \\
$\mathbf{5}$ & 20,86 & 27,89 & 24,54 \\
$\mathbf{6}$ & 3,57 & 8,59 & 6,25 \\
$\mathbf{7}$ & 3,57 & 2,34 & 1,78 \\
$\mathbf{8}$ & 2,57 & 4,35 & 7,25 \\
$\mathbf{9}$ & 14,95 & 17,96 & 9,70 \\
\hline
\end{tabular}

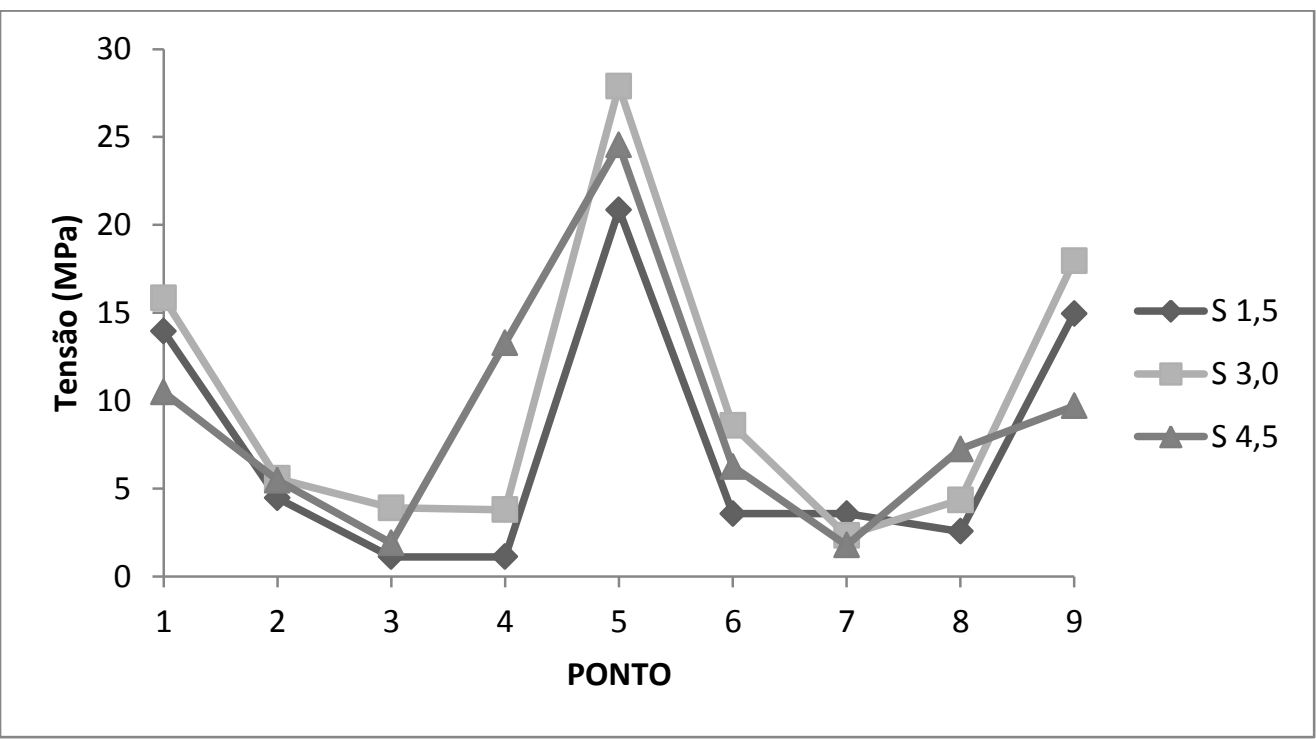

Figura 24 - Gráfico das tensões em cada ponto analisado no carregamento oclusal distribuído - S 1,5: pilar sólido e transmucoso de 1,5 mm; S 3,0: pilar sólido e transmucoso de $3,0 \mathrm{~mm}$; $\mathrm{S} 4,5$ : pilar sólido e transmucoso de $4,5 \mathrm{~mm}$. 


\subsection{Implante adjacente ao segundo pré-molar inferior}

\subsubsection{Transmucoso de 1,5 mm (comparação entre pilar PP e S)}

As figuras 25 e 26 e a tabela 8 apresentam os resultados obtidos a partir do carregamento dos modelos com pilar PP e $S$ com transmucoso de 1,5 mm. Nos pontos 1, 5, 6 e 7 as maiores tensões estiveram no modelo com pilar PP. Em 3 e 4 os valores das tensões foram iguais entre os pontos de mesma numeração. No ponto 2 a maior tensão foi no modelo com pilar S. O pilar PP aumentou em $14 \%$ e $59 \%$ as tensões no ápice do implante e na crista óssea peri-implantar distal respectivamente. O pilar PP diminuiu em $50 \%$ a tensão na crista óssea adjacente ao segundo pré-molar.
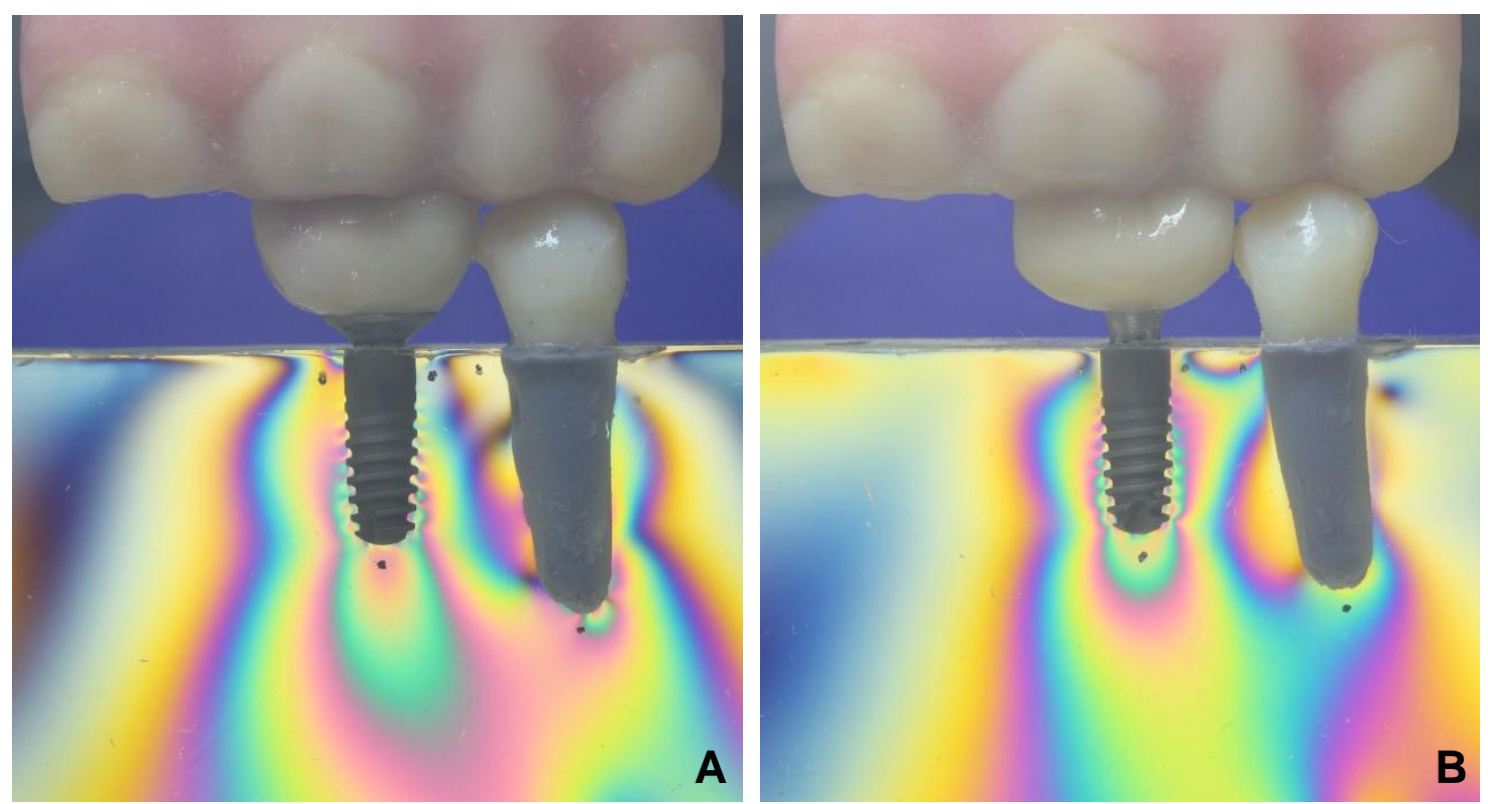

Figura 25 - Imagens fotoelásticas: A) pilar PP com transmucoso de 1,5 mm; B) pilar S com transmucoso de $1,5 \mathrm{~mm}$. 
Tabela 8 - Tensões incidentes nos pontos de 1 a 7 dos modelos fotoelásticos com pilar PP e S de transmucoso de 1,5 mm.

\begin{tabular}{ccc}
\hline \multirow{2}{*}{ Ponto } & \multicolumn{2}{c}{ Tensão (MPa) } \\
\cline { 2 - 3 } & PP 1,5 & S 1,5 \\
\hline $\mathbf{1}$ & 22,87 & 13,27 \\
$\mathbf{2}$ & 4,46 & 8,92 \\
$\mathbf{3}$ & 13,72 & 14,17 \\
$\mathbf{4}$ & 13,72 & 14,17 \\
$\mathbf{5}$ & 33,46 & 29,45 \\
$\mathbf{6}$ & 17,74 & 11,15 \\
$\mathbf{7}$ & 17,74 & 11,15 \\
\hline
\end{tabular}

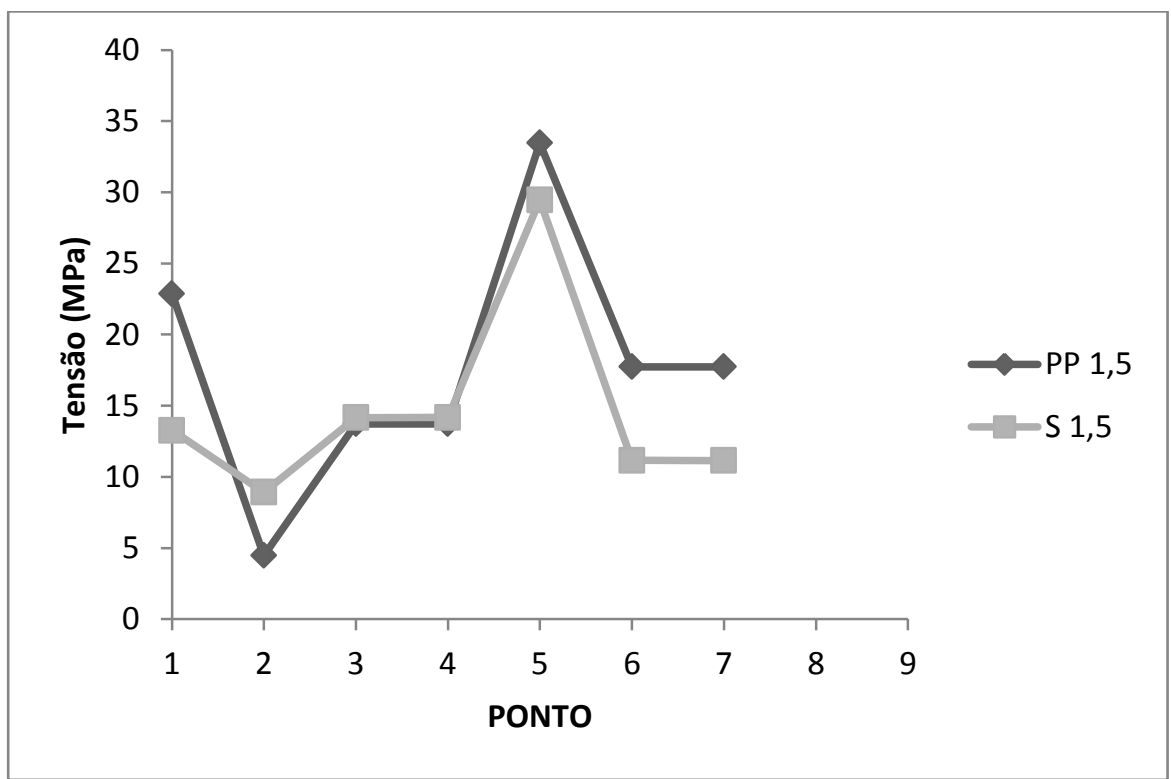

Figura 26 - Gráfico das tensões em cada ponto analisado no carregamento oclusal distribuído - PP 1,5: pilar de parafuso passante e transmucoso de 1,5 mm; S 1,5: pilar sólido e transmucoso de 1,5 mm.

\subsubsection{Transmucoso de 3,0 mm (comparação entre pilar PP e S)}

As figuras 27 e 28 e a tabela 9 apresentam os resultados obtidos a partir do carregamento dos modelos com pilar PP e $S$ com transmucoso de $3,0 \mathrm{~mm}$. Nos pontos 1 e 5 os valores das tensões foram iguais entre os pontos de mesma numeração. Em 2, 3 e 4 as maiores tensões estiveram no modelo com pilar S. Nos pontos 6 e 7 as maiores tensões foram no modelo com pilar PP. No ápice do implante não houve diferença na distribuição de tensão quando se alterou o desenho do pilar. Na crista óssea peri-implantar mesial, o pilar PP reduziu em $43 \%$ a tensão. 
Porém, na crista óssea peri-implantar distal o mesmo pilar aumentou a tensão em $12 \%$. Na crista óssea adjacente ao segundo pré-molar, a tensão foi $81 \%$ menor com o pilar PP.
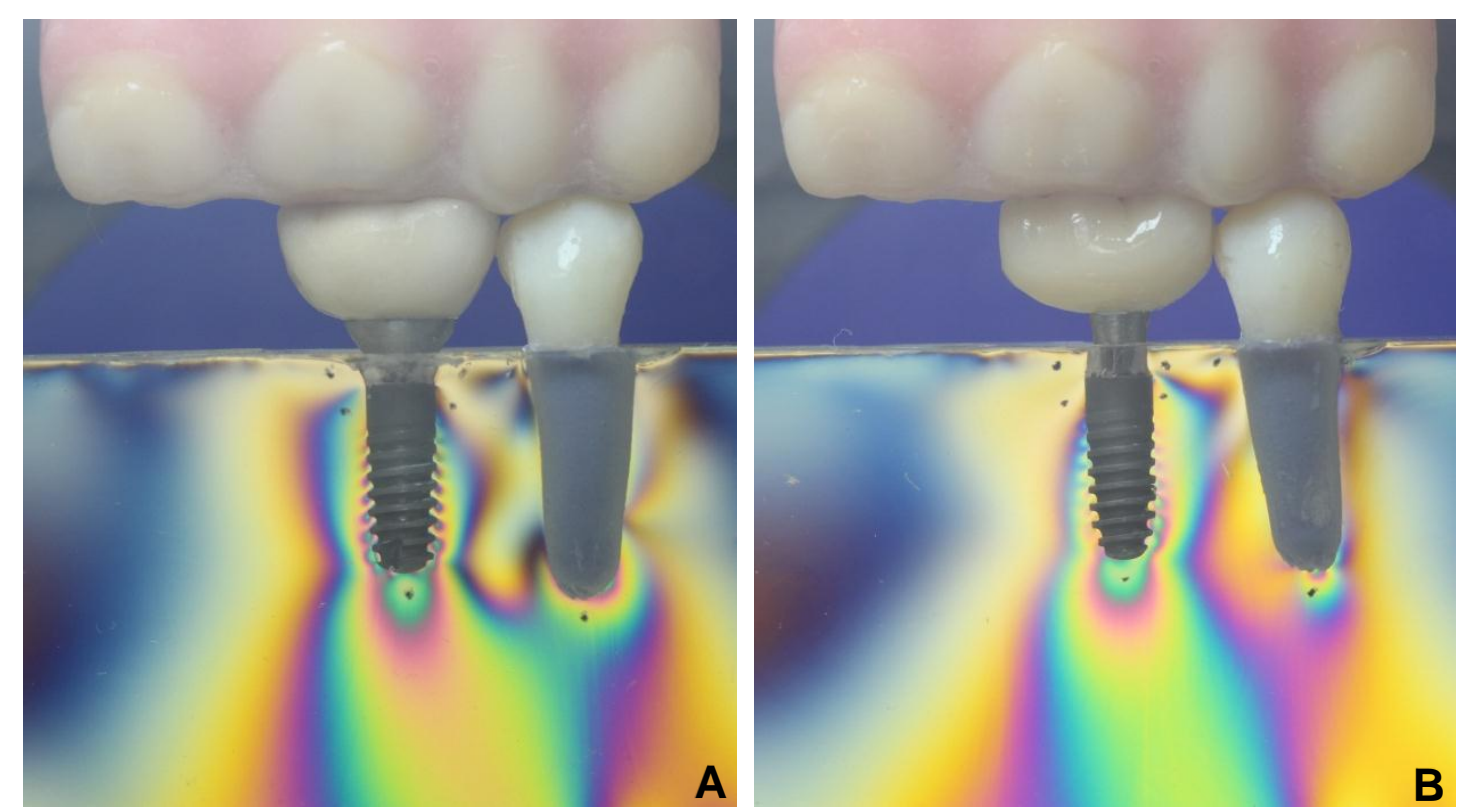

Figura 27 - Imagens fotoelásticas: A) pilar PP com transmucoso de $3,0 \mathrm{~mm}$; B) pilar S com transmucoso de $3,0 \mathrm{~mm}$.

Tabela 9 - Tensões incidentes nos pontos de 1 a 7 dos modelos fotoelásticos com pilar PP e S de transmucoso de $3,0 \mathrm{~mm}$.

\begin{tabular}{ccc}
\hline \multirow{2}{*}{ Ponto } & \multicolumn{2}{c}{ Tensões (MPa) } \\
\cline { 2 - 3 } & PP 3,0 & S 3,0 \\
\hline $\mathbf{1}$ & 16,51 & 16,40 \\
$\mathbf{2}$ & 0,56 & 2,90 \\
$\mathbf{3}$ & 3,90 & 6,80 \\
$\mathbf{4}$ & 6,36 & 16,95 \\
$\mathbf{5}$ & 29,78 & 29,78 \\
$\mathbf{6}$ & 13,50 & 7,70 \\
$\mathbf{7}$ & 5,58 & 4,91 \\
\hline
\end{tabular}




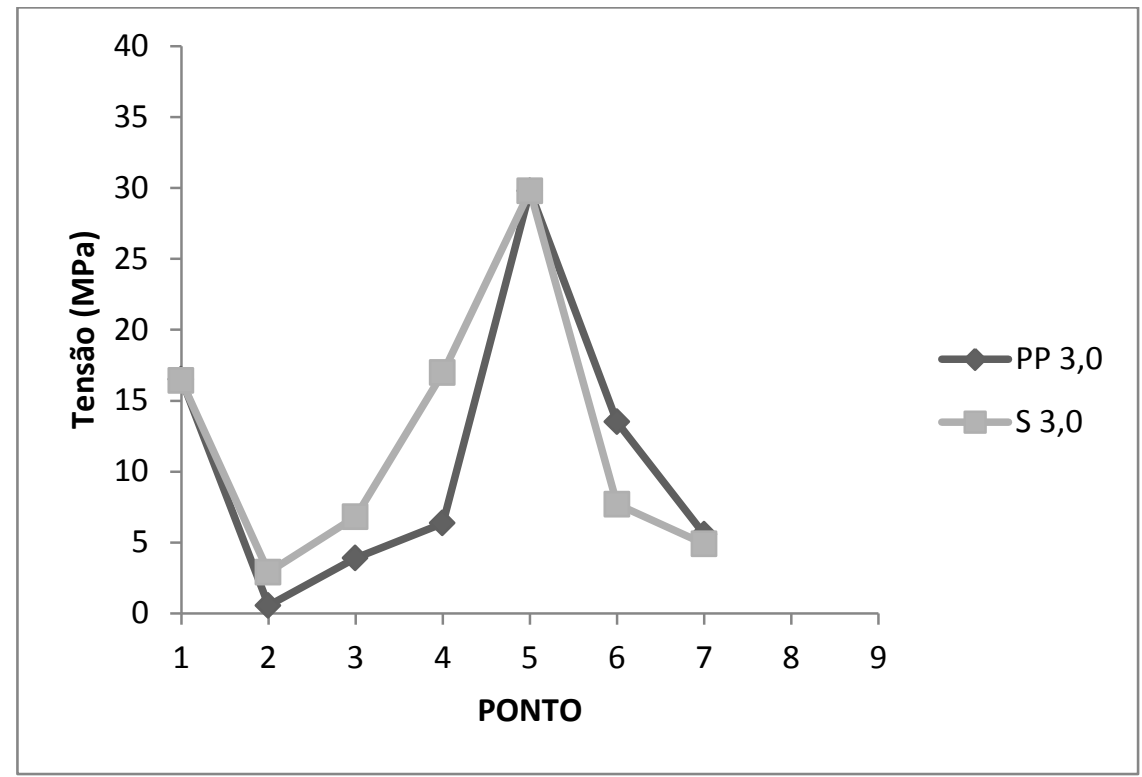

Figura 28 - Gráfico das tensões em cada ponto analisado no carregamento oclusal distribuído - PP 3,0: pilar de parafuso passante e transmucoso de 3,0 mm; S 3,0: pilar sólido e transmucoso de 3,0 mm.

\subsubsection{Transmucoso de 4,5 mm (comparação entre pilar PP e S)}

As figuras 29 e 30 e a tabela 10 apresentam os resultados obtidos a partir do carregamento dos modelos com pilar PP e $S$ com transmucoso de 4,5 mm. Nos pontos 1, 2, 3, 5 e 7 as maiores tensões estiveram no modelo com pilar S. No ponto 4 as tensões foram iguais, em 6 a maior tensão esteve no modelo com pilar PP. Utilizando o pilar PP, as cristas ósseas peri-implantares mesial e distal recebem $63 \%$ e 33\% menos tensão respectivamente. No ápice do implante houve um decréscimo de $13 \%$ na tensão quando do uso do pilar PP. Na crista óssea adjacente ao prémolar, o pilar PP reduziu a tensão em 14\%. 

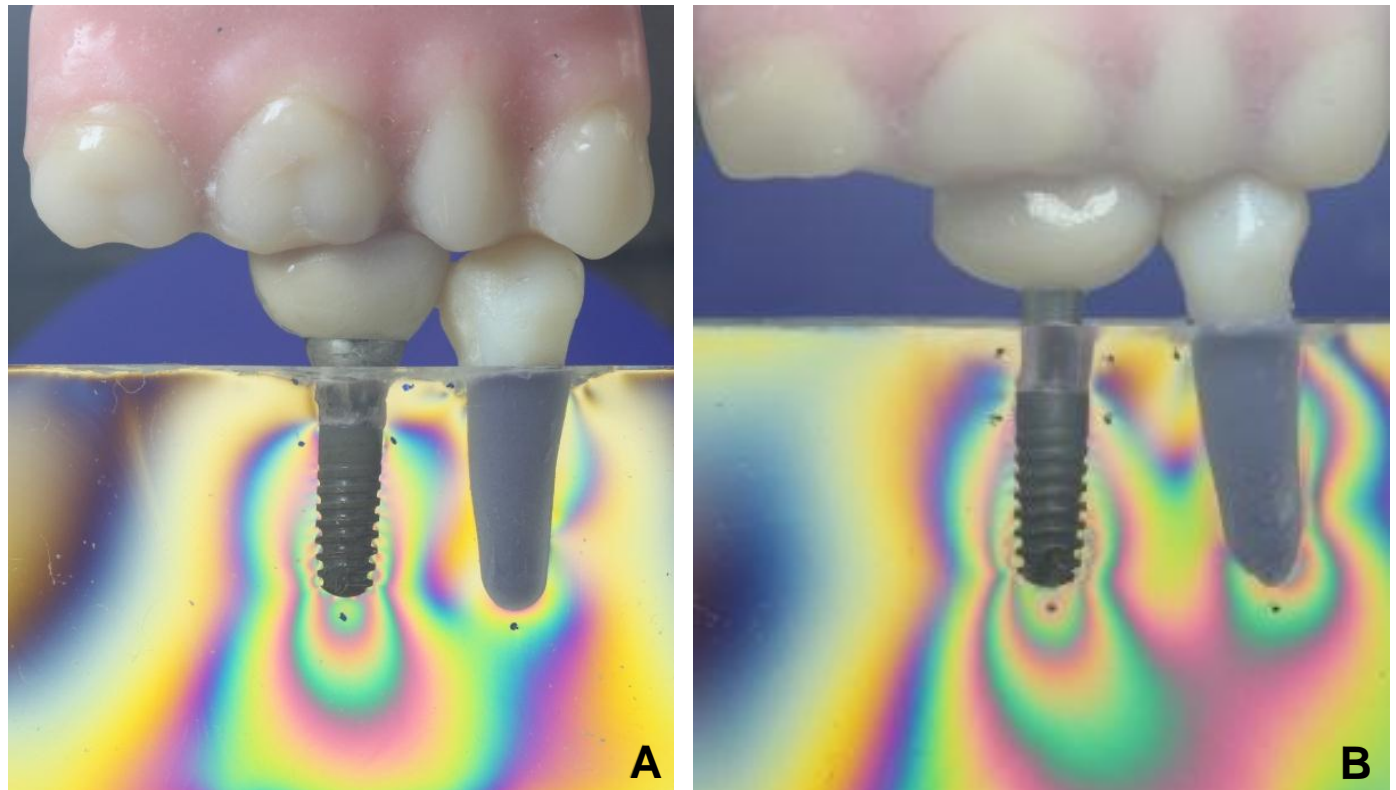

Figura 29 - Imagens fotoelásticas: A) pilar PP com transmucoso de 4,5 mm; B) pilar S com transmucoso de $4,5 \mathrm{~mm}$.

Tabela 10 - Tensões incidentes nos pontos de 1 a 7 dos modelos fotoelásticos com pilar PP e S de transmucoso de $4,5 \mathrm{~mm}$.

\begin{tabular}{ccc}
\multirow{2}{*}{ Ponto } & \multicolumn{2}{c}{ Tensão $(\mathrm{MPa})$} \\
\cline { 2 - 3 } & PP 4,5 & $\mathbf{S ~ 4 , 5}$ \\
\hline $\mathbf{1}$ & 21,75 & 25,88 \\
$\mathbf{3}$ & 4,13 & 4,80 \\
$\mathbf{4}$ & 2,45 & 6,69 \\
$\mathbf{5}$ & 16,62 & 16,40 \\
$\mathbf{6}$ & 37,03 & 42,50 \\
$\mathbf{7}$ & 17,29 & 14,72 \\
\end{tabular}




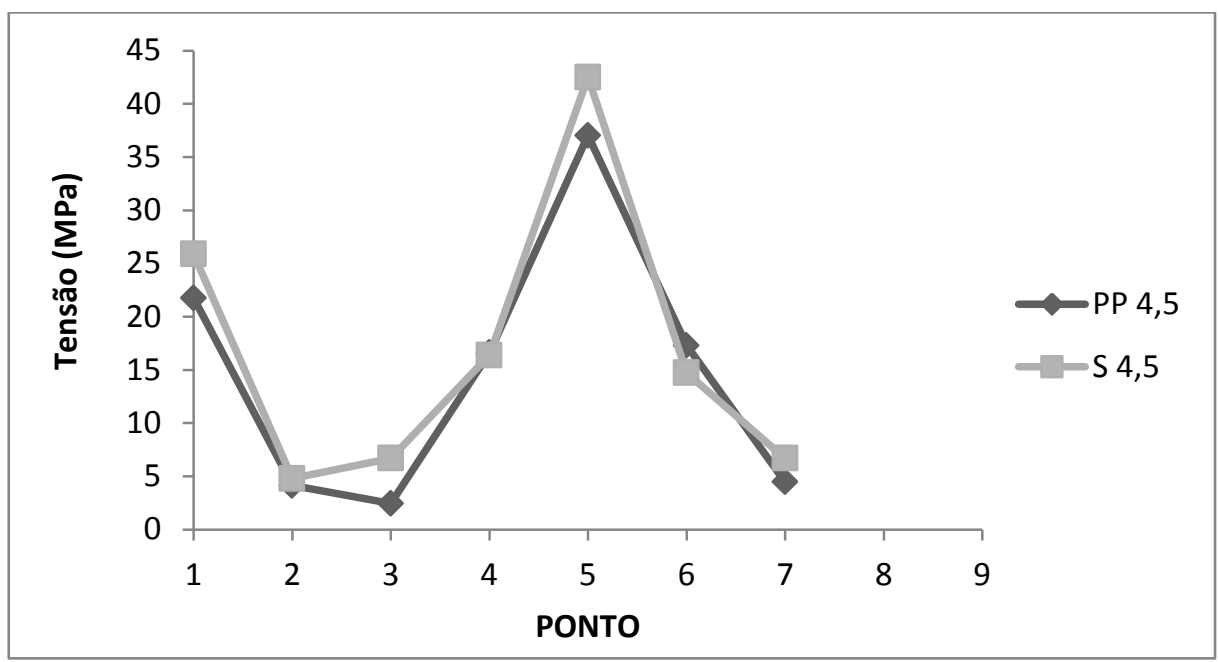

Figura 30 - Gráfico das tensões em cada ponto analisado no carregamento oclusal distribuído - PP 4,5: pilar de parafuso passante e transmucoso de 4,5 $\mathrm{mm}$; S 4,5: pilar sólido e transmucoso de $4,5 \mathrm{~mm}$.

\subsubsection{Pilar PP (transmucoso de 1,5 mm, 3,0 $\mathrm{mm}$ e 4,5 mm)}

A tabela 11 e a figura 31 apresentam os resultados obtidos a partir do carregamento dos modelos com pilar PP com alturas de transmucoso de 1,5 mm, 3,0 $\mathrm{mm}$ e 4,5 mm. Nos pontos 1, 2, 5 e 6 as maiores tensões estiveram nos modelos com implantes equicristal e infraósseo a $3,0 \mathrm{~mm}$, sendo os valores iguais entre os pontos de mesma numeração. Nos pontos 3 e 7 as tensões mais elevadas foram no modelo com implante equicristal. Em 4 a maior tensão esteve no modelo com implante infraósseo a 3,0 mm. Na crista óssea peri-implantar mesial, os implantes infraósseo a $1,5 \mathrm{~mm}$ e a 3,0 $\mathrm{mm}$ reduziram as tensões em $72 \%$ e $82 \%$ respectivamente. Na crista óssea peri-implantar distal, o decréscimo de tensão motivado pelos implantes infraósseo a $1,5 \mathrm{~mm}$ e a $3,0 \mathrm{~mm}$ foi de $69 \%$ e $75 \%$ respectivamente. $O$ implante infraósseo a $1,5 \mathrm{~mm}$ diminuiu a tensão no ápice do implante e na crista óssea adjacente ao segundo pré-molar em $20 \%$ e $88 \%$ respectivamente. 
Tabela 11 - Tensões incidentes nos pontos de 1 a 7 dos modelos fotoelásticos com pilar PP de transmucoso de $1,5 \mathrm{~mm}, 3,0 \mathrm{~mm}$ e $4,5 \mathrm{~mm}$.

\begin{tabular}{cccc}
\hline \multirow{2}{*}{ Ponto } & \multicolumn{3}{c}{ Tensão (MPa) } \\
\cline { 2 - 4 } & PP 1,5 & PP 3,0 & PP 4,5 \\
\hline $\mathbf{1}$ & 22,87 & 16,51 & 21,75 \\
$\mathbf{2}$ & 4,46 & 0,56 & 4,13 \\
$\mathbf{3}$ & 13,72 & 3,90 & 2,45 \\
$\mathbf{4}$ & 13,72 & 6,36 & 16,62 \\
$\mathbf{5}$ & 33,46 & 29,78 & 37,03 \\
$\mathbf{6}$ & 17,74 & 13,50 & 17,29 \\
$\mathbf{7}$ & 17,74 & 5,58 & 4,46 \\
\hline
\end{tabular}

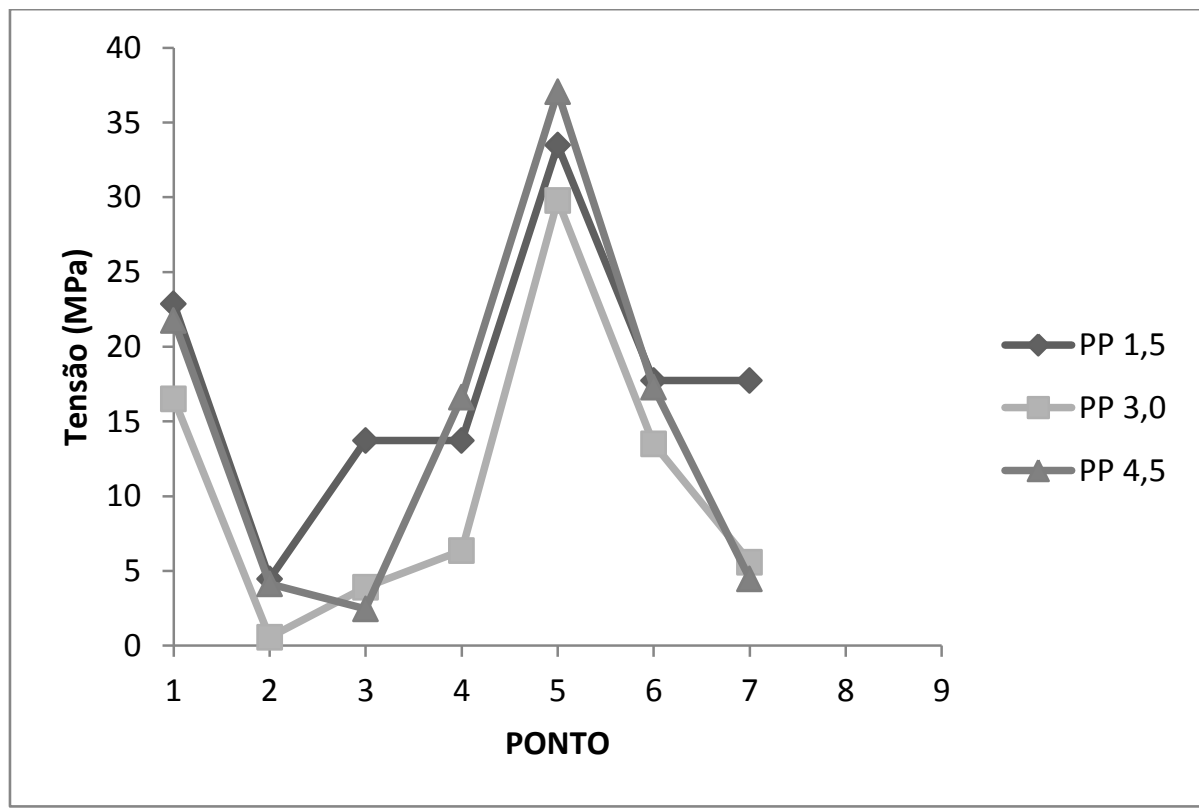

Figura 31 - Gráfico das tensões em cada ponto analisado no carregamento oclusal distribuído - PP 1,5: pilar de parafuso passante e transmucoso de 1,5 mm; PP 3,0: pilar de parafuso passante e transmucoso de 3,0 mm; PP 4,5: pilar de parafuso passante e transmucoso de $4,5 \mathrm{~mm}$.

\subsubsection{Pilar S (transmucoso de $1,5 \mathrm{~mm}, 3,0 \mathrm{~mm} \mathrm{e} 4,5 \mathrm{~mm}$ )}

A tabela 12 e a figura 32 apresentam os resultados obtidos a partir do carregamento dos modelos com pilar $\mathrm{S}$ com alturas de transmucoso de 1,5 mm, 3,0 $\mathrm{mm}$ e 4,5 mm. Nos pontos 1, 4, 5 e 6 as maiores tensões foram no modelo com implante infraósseo a 3,0 $\mathrm{mm}$. Porém, no ponto 4 os valores das tensões foram iguais nos modelos com implantes infraósseo a 1,5 mm e a 3,0 mm. Em 2, 3 e 7 as maiores tensões estiveram no modelo com implante equicristal. Na crista óssea peri- 
implantar mesial, o posicionamento infraósseo do implante reduziu as tensões em $53 \%$. Na crista óssea peri-implantar distal, os implantes infraósseo a 1,5 mm e a 3,0 $\mathrm{mm}$ reduziram as tensões em $56 \%$ e $40 \%$ respectivamente. No ápice do implante, os implantes equicristal e infraósseo a $1,5 \mathrm{~mm}$ diminuíram a tensão em $31 \%$. Na crista óssea adjacente ao segundo pré-molar, os implantes infraósseo a 1,5 mm e a 3,0 $\mathrm{mm}$ reduziram a tensão em $68 \%$ e $46 \%$ respectivamente.

Tabela 12 - Tensões incidentes nos pontos de 1 a 7 dos modelos fotoelásticos com pilar S de transmucoso de $1,5 \mathrm{~mm}, 3,0 \mathrm{~mm}$ e $4,5 \mathrm{~mm}$.

\begin{tabular}{cccc}
\hline & \multicolumn{3}{c}{ Tensão (MPa) } \\
\cline { 2 - 4 } Ponto & $\mathbf{S ~ 1 , 5}$ & $\mathbf{S ~ 3 , 0}$ & $\mathbf{S ~ 4 , 5}$ \\
\hline $\mathbf{1}$ & 13,27 & 16,40 & 25,88 \\
$\mathbf{2}$ & 8,92 & 2,90 & 4,80 \\
$\mathbf{4}$ & 14,17 & 6,80 & 6,69 \\
$\mathbf{5}$ & 14,17 & 16,95 & 16,40 \\
$\mathbf{6}$ & 29,45 & 29,78 & 42,50 \\
$\mathbf{7}$ & 11,15 & 7,70 & 14,72 \\
\hline
\end{tabular}

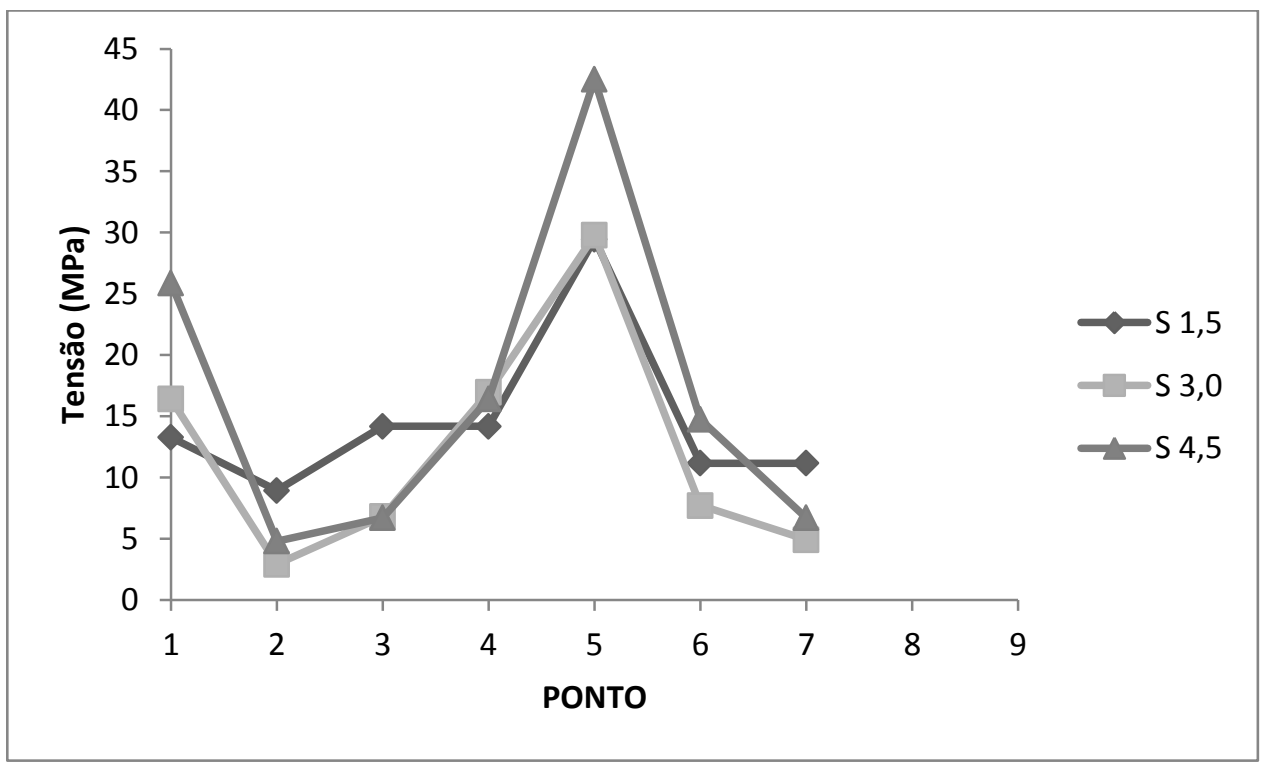

Figura 32 - Gráfico das tensões em cada ponto analisado no carregamento oclusal distribuído - S 1,5: pilar sólido e transmucoso de 1,5 mm; - S 3,0: pilar sólido e transmucoso de $3,0 \mathrm{~mm}$; - S 4,5: pilar sólido e transmucoso de 4,5 mm. 


\subsection{Implante Isolado (Carregamento Central)}

\subsubsection{Transmucoso de 1,5 mm (comparação entre pilar PP e S)}

As figuras 33 e 34 e a tabela 13 apresentam os resultados obtidos a partir do carregamento dos modelos com pilar PP e S com transmucoso de 1,5 mm. Em todos os pontos ( 3 a 7 ), as maiores tensões estiveram no modelo com pilar PP. Sendo que com este pilar, as tensões nas cristas ósseas peri-implantares mesial e distal e no ápice do implante aumentaram respectivamente $35 \%, 80 \%$ e $72 \%$.
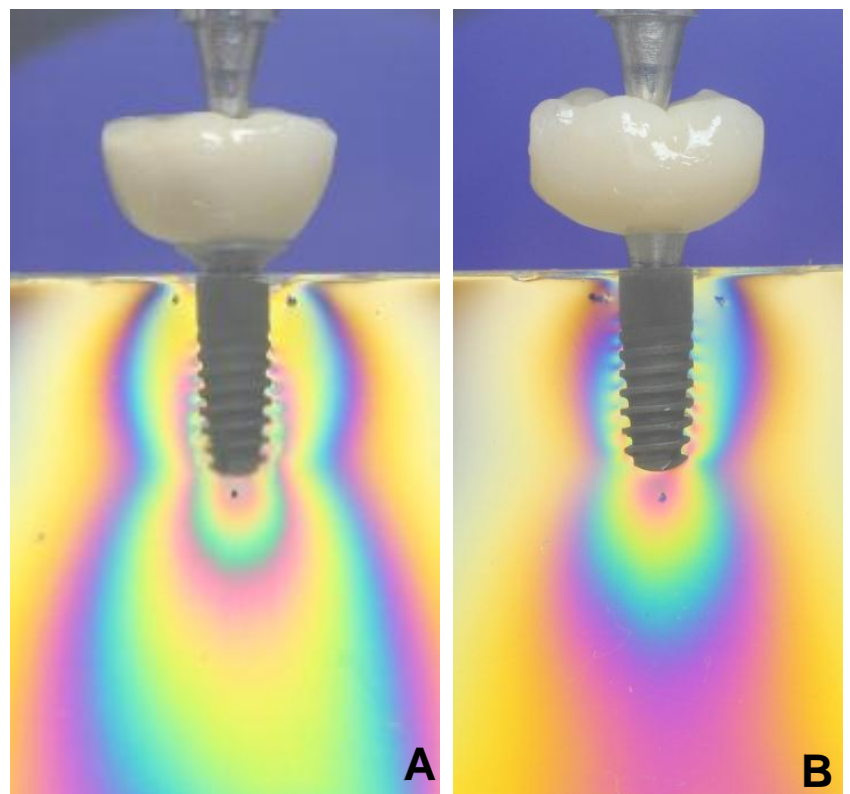

Figura 33 - Imagens fotoelásticas: A) pilar PP com transmucoso de $1,5 \mathrm{~mm}$; B) pilar $\mathrm{S}$ com transmucoso de $1,5 \mathrm{~mm}$.

Tabela 13 - Tensões incidentes nos pontos de 3 a 7 dos modelos fotoelásticos com pilar PP e S de transmucoso de 1,5 $\mathrm{mm}$

\begin{tabular}{ccc}
\hline \multirow{2}{*}{ Ponto } & \multicolumn{2}{c}{ Tensão (MPa) } \\
\cline { 2 - 3 } & PP 1,5 & S 1,5 \\
\hline $\mathbf{3}$ & 16,84 & 12,49 \\
$\mathbf{4}$ & 16,84 & 12,49 \\
$\mathbf{5}$ & 34,24 & 19,86 \\
$\mathbf{6}$ & 16,06 & 8,92 \\
$\mathbf{7}$ & 16,06 & 8,92 \\
\hline
\end{tabular}




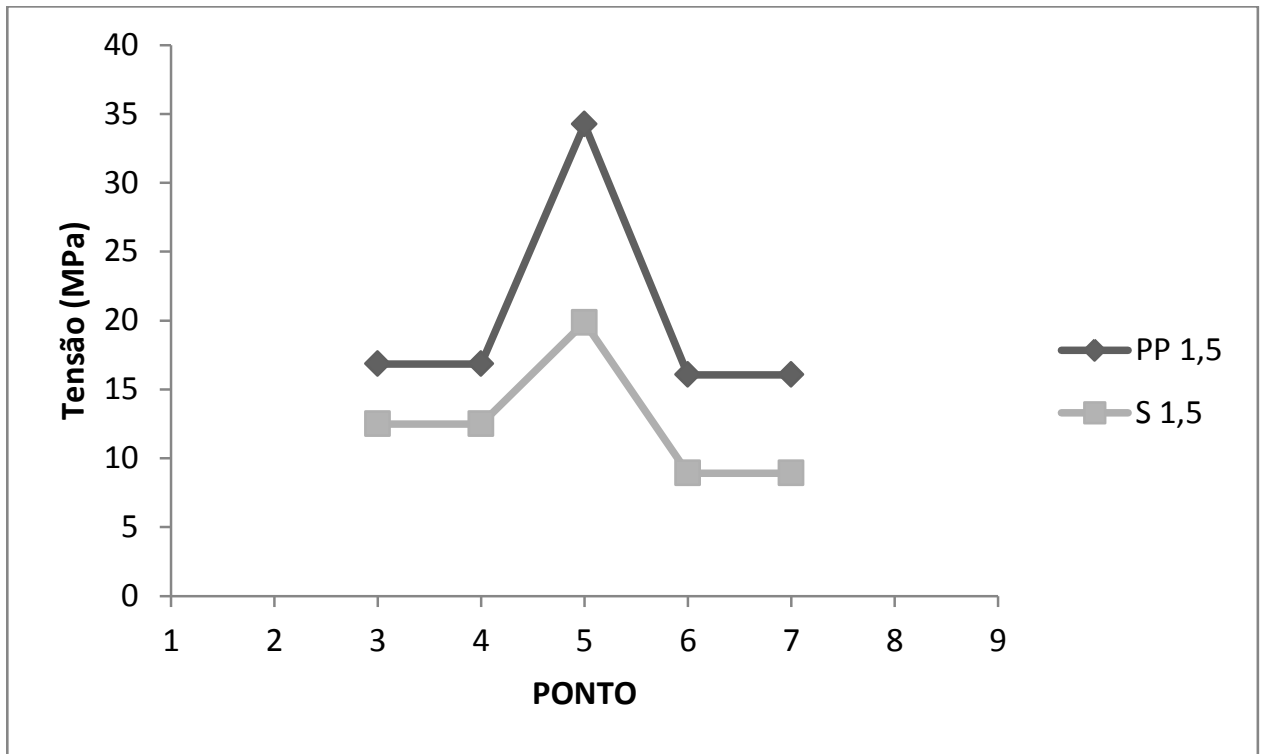

Figura 34 - Gráfico das tensões em cada ponto analisado no carregamento pontual central - PP 1,5: pilar de parafuso passante e transmucoso de 1,5 mm; S 1,5: pilar sólido e transmucoso de $1,5 \mathrm{~mm}$.

\subsubsection{Transmucoso de 3,0 mm (comparação entre pilar PP e S)}

As figuras 35 e 36 e a tabela 14 apresentam os resultados obtidos a partir do carregamento dos modelos com pilar PP e $S$ com transmucoso de $3,0 \mathrm{~mm}$. Nos pontos 3 e 7 as maiores tensões estiveram no modelo com pilar S. Em 4 e 5 as tensões foram iguais entre os pontos de mesma numeração. No ponto 6 a tensão mais elevada foi no modelo com pilar PP. No ápice do implante, o comportamento mecânico foi semelhante entre os pilares. Nas cristas ósseas peri-implantares mesial e distal, o pilar PP reduziu as tensões em $32 \%$ e $22 \%$ respectivamente. 


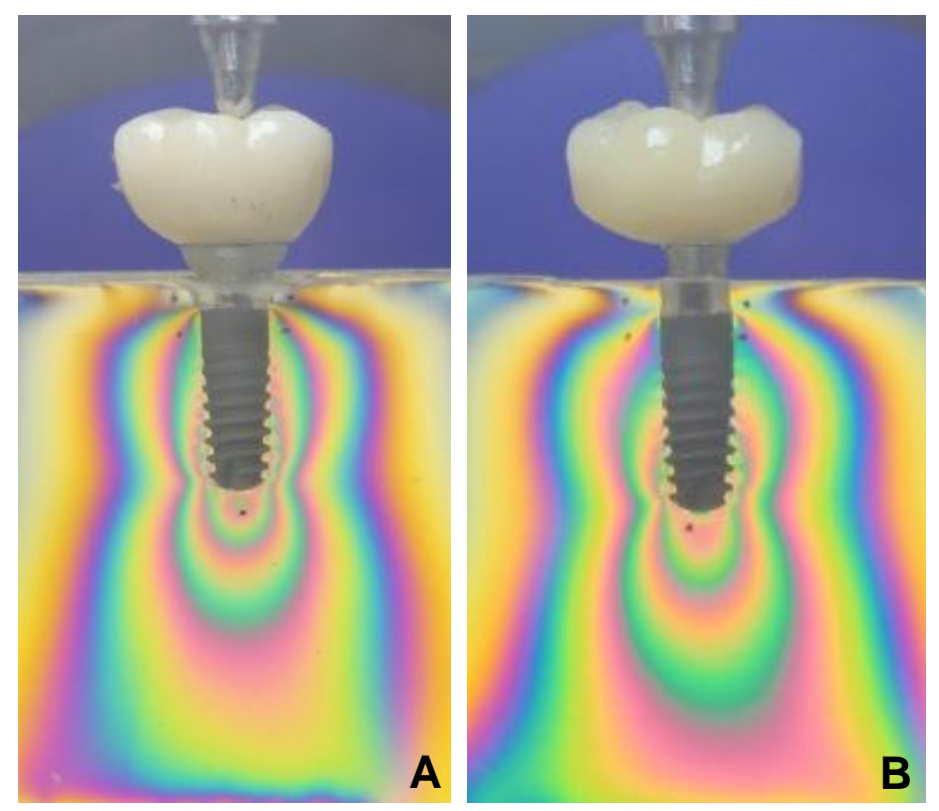

Figura 35 - Imagens fotoelásticas: A) pilar PP com transmucoso de $3,0 \mathrm{~mm}$; B) pilar $\mathrm{S}$ com transmucoso de 3,0 $\mathrm{mm}$.

Tabela 14 - Tensões incidentes nos pontos de 3 a 7 dos modelos fotoelásticos com pilar PP e $\mathrm{S}$ de transmucoso de $3,0 \mathrm{~mm}$.

Tensão (MPa)

\begin{tabular}{ccc} 
Ponto & PP 3,0 & S 3,0 \\
\hline $\mathbf{3}$ & 9,82 & 14,39 \\
$\mathbf{4}$ & 23,42 & 23,31 \\
$\mathbf{5}$ & 44,62 & 43,73 \\
$\mathbf{6}$ & 20,97 & 17,40 \\
$\mathbf{7}$ & 10,82 & 13,94 \\
\hline
\end{tabular}




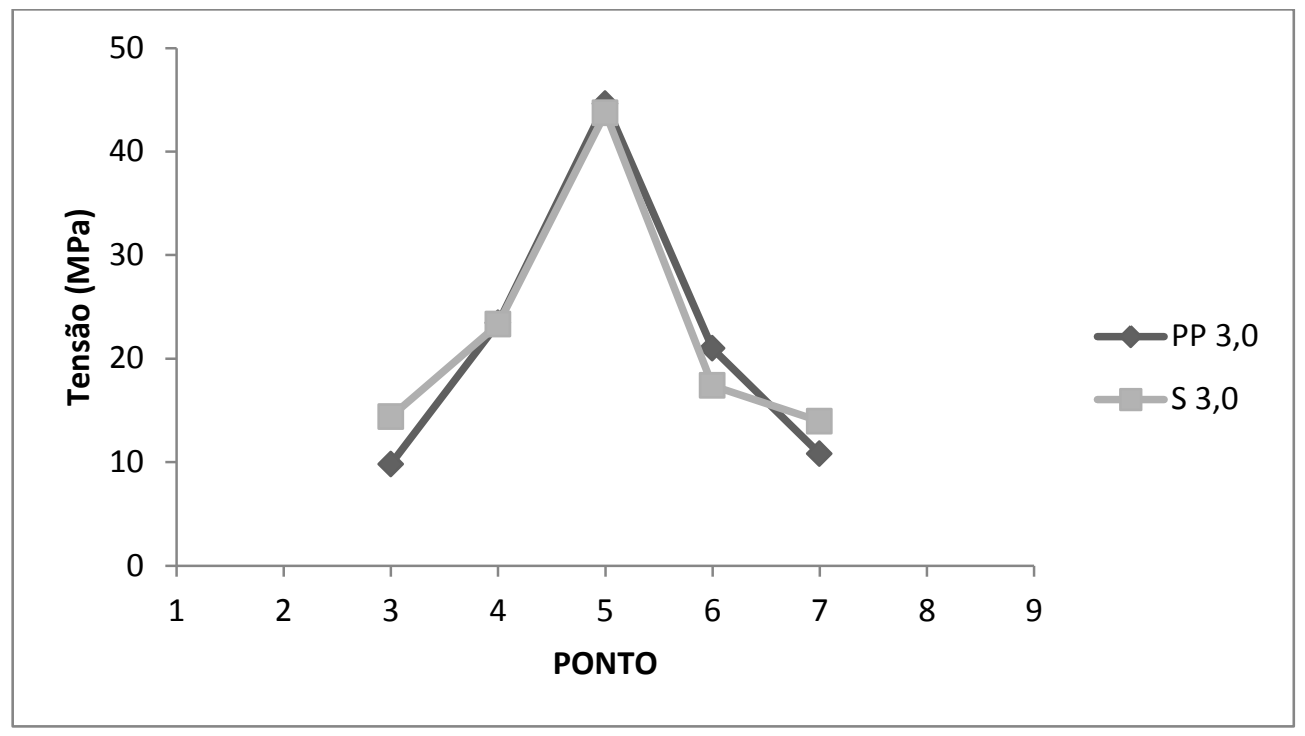

Figura 36 - Gráfico das tensões em cada ponto analisado no carregamento pontual central - PP 3,0: pilar de parafuso passante e transmucoso de 3,0 mm; S 3,0: pilar sólido e transmucoso de $3,0 \mathrm{~mm}$.

\subsubsection{Transmucoso de 4,5 mm (comparação entre pilar PP e S)}

As figuras 37 e 38 e a tabela 15 apresentam os resultados obtidos a partir do carregamento dos modelos com pilar PP e $S$ com transmucoso de 4,5 mm. Nos pontos 3, 6 e 7 as tensões foram iguais entre os pontos de mesma numeração. Em 4 o modelo com pilar PP recebeu maior tensão, oposto do que ocorreu no ponto 5, no qual o modelo com pilar $S$ registrou maior tensão. No ápice do implante a tensão foi $19 \%$ menor quando do uso do pilar PP. Nas cristas ósseas peri-implantares não houve diferença entre os pilares na dissipação de tensão. 


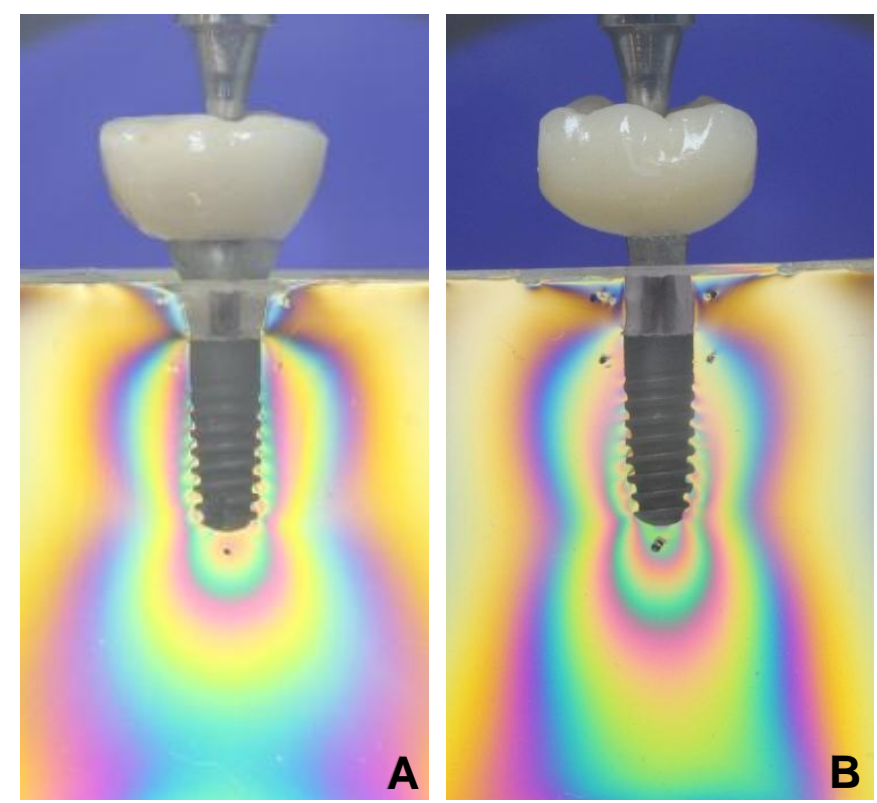

Figura 37 - Imagens fotoelásticas: A) pilar PP com transmucoso de $4,5 \mathrm{~mm}$; B) pilar $\mathrm{S}$ com transmucoso de $4,5 \mathrm{~mm}$.

Tabela 15 - Tensões incidentes nos pontos de 3 a 7 dos modelos fotoelásticos com pilar PP e $S$ de transmucoso de $4,5 \mathrm{~mm}$

Tensão (MPa)

\begin{tabular}{ccc} 
Ponto & PP 4,5 & S 4,5 \\
\hline $\mathbf{3}$ & 10,04 & 11,15 \\
$\mathbf{4}$ & 20,19 & 14,61 \\
$\mathbf{5}$ & 31,34 & 38,59 \\
$\mathbf{6}$ & 18,41 & 16,95 \\
$\mathbf{7}$ & 11,15 & 11,15 \\
\hline
\end{tabular}




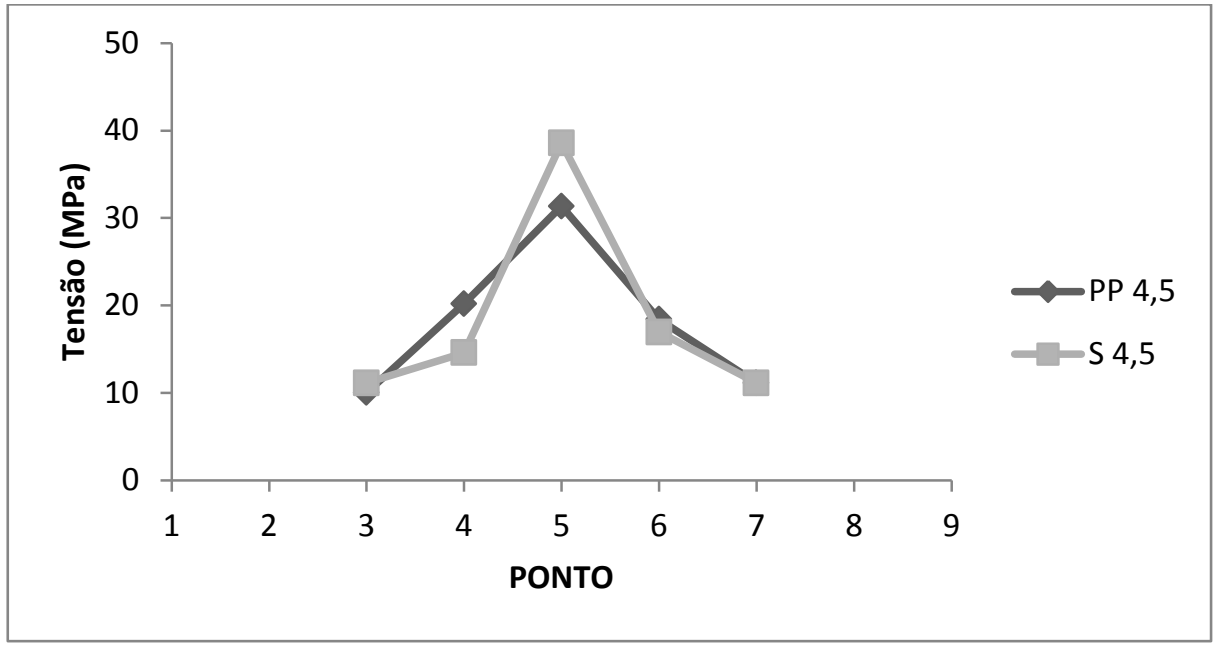

Figura 38 - Gráfico das tensões em cada ponto analisado no carregamento pontual central - PP 4,5: pilar de parafuso passante e transmucoso de 4,5 $\mathrm{mm}$; S 4,5: pilar sólido e transmucoso de $4,5 \mathrm{~mm}$.

\subsubsection{Pilar PP (transmucoso de 1,5 mm, 3,0 $\mathrm{mm}$ e 4,5 mm)}

A tabela 16 e a figura 39 apresentam os resultados obtidos a partir do carregamento dos modelos com pilar PP com alturas de transmucoso de $1,5 \mathrm{~mm}$, $3,0 \mathrm{~mm}$ e $4,5 \mathrm{~mm}$. Nos pontos 3 e 7 as maiores tensões estiveram no modelo com implante equicristal. Em 4, 5 e 6 as tensões mais elevadas foram no modelo com implante infraósseo a 1,5 mm. Na crista óssea peri-implantar mesial, os implantes infraósseo motivaram tensões $42 \%$ menores. No ápice do implante, os implantes equicristal e infraósseo a 3,0 mm reduziram as tensões em 30\%. Na crista óssea peri-implantar distal, os implantes infraósseo diminuíram em $33 \%$ as tensões.

Tabela 16 - Tensões incidentes nos pontos de 3 a 7 dos modelos fotoelásticos com pilar PP de transmucoso de $1,5 \mathrm{~mm}, 3,0 \mathrm{~mm}$ e $4,5 \mathrm{~mm}$.

\begin{tabular}{cccc} 
Ponto & \multicolumn{3}{c}{ Tensão (MPa) } \\
\cline { 2 - 4 } & PP 1,5 & PP 3,0 & PP 4,5 \\
\hline $\mathbf{3}$ & 16,84 & 9,82 & 10,04 \\
$\mathbf{4}$ & 16,84 & 23,42 & 20,19 \\
$\mathbf{5}$ & 34,24 & 44,62 & 31,34 \\
$\mathbf{6}$ & 16,06 & 20,97 & 18,41 \\
$\mathbf{7}$ & 16,06 & 10,82 & 11,15 \\
\hline
\end{tabular}




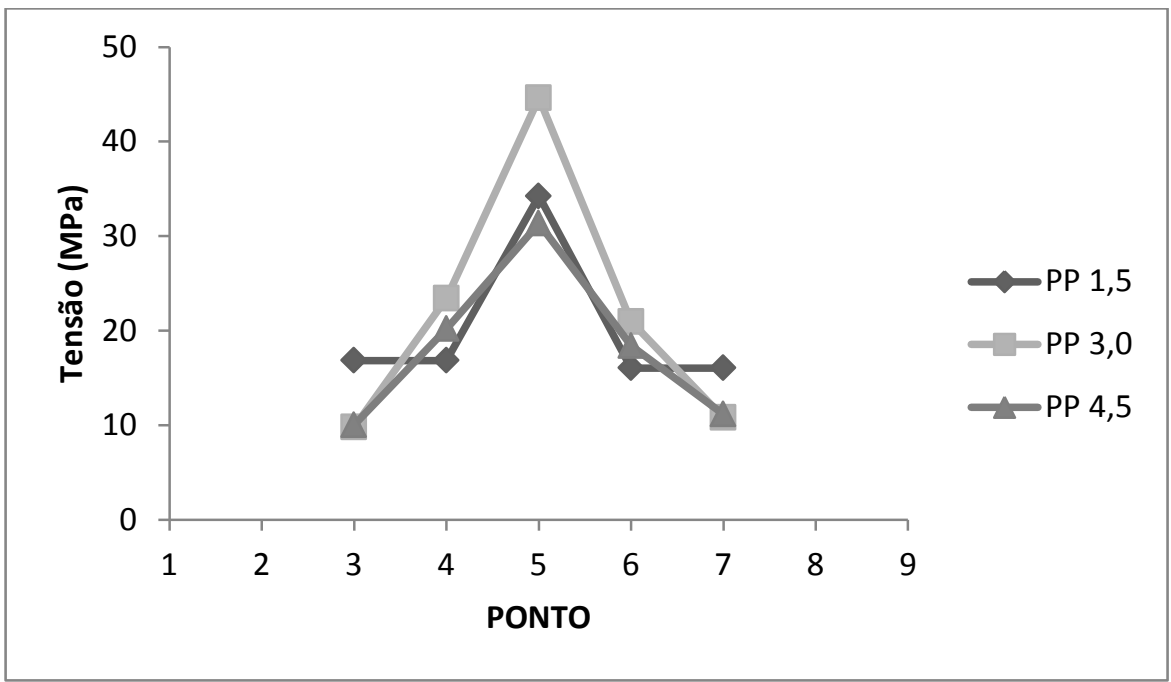

Figura 39 - Gráfico das tensões em cada ponto analisado no carregamento pontual central - PP 1,5: pilar de parafuso passante e transmucoso de 1,5 $\mathrm{mm}$. PP 3,0: pilar de parafuso passante e transmucoso de 3,0 mm; PP 4,5: pilar de parafuso passante e transmucoso de $4,5 \mathrm{~mm}$.

\subsubsection{Pilar S (transmucoso de 1,5 mm, 3,0 $\mathrm{mm}$ e 4,5 mm)}

A tabela 17 e a figura 40 apresentam os resultados obtidos a partir do carregamento dos modelos com pilar $\mathrm{S}$ com alturas de transmucoso de $1,5 \mathrm{~mm}, 3,0$ $\mathrm{mm}$ e 4,5 mm. Nos pontos 3, 4, 5 e 7 as maiores tensões foram no modelo com implante infraósseo a $1,5 \mathrm{~mm}$. No ponto 6 as maiores tensões foram nos modelos com implantes infraósseo. Na crista óssea peri-implantar mesial, os implantes equicristal e infraósseo a $3,0 \mathrm{~mm}$ reduziram as tensões em $13 \%$ e $22 \%$ respectivamente. No ápice do implante, os implantes equicristal e infraósseo a 3,0 mm diminuíram as tensões em $55 \%$ e $12 \%$ respectivamente. Na crista óssea periimplantar distal, os implantes equicristal e infraósseo a 3,0 mm reduziram as tensões em $36 \%$ e $25 \%$ respectivamente. 
Tabela 17 - Tensões incidentes nos pontos de 3 a 7 dos modelos fotoelásticos com pilar $\mathrm{S}$ de transmucoso de $1,5 \mathrm{~mm}, 3,0 \mathrm{~mm}$ e $4,5 \mathrm{~mm}$.

\begin{tabular}{cccc} 
& \multicolumn{3}{c}{ Tensão (MPa) } \\
\cline { 2 - 4 } Ponto & $\mathbf{S ~ 1 , 5}$ & $\mathbf{S ~ 3 , 0}$ & $\mathbf{S ~ 4 , 5}$ \\
\hline $\mathbf{3}$ & 12,49 & 14,39 & 11,15 \\
$\mathbf{5}$ & 12,49 & 23,31 & 14,61 \\
$\mathbf{6}$ & 19,86 & 43,73 & 38,59 \\
$\mathbf{7}$ & 8,92 & 17,40 & 16,95 \\
\hline
\end{tabular}

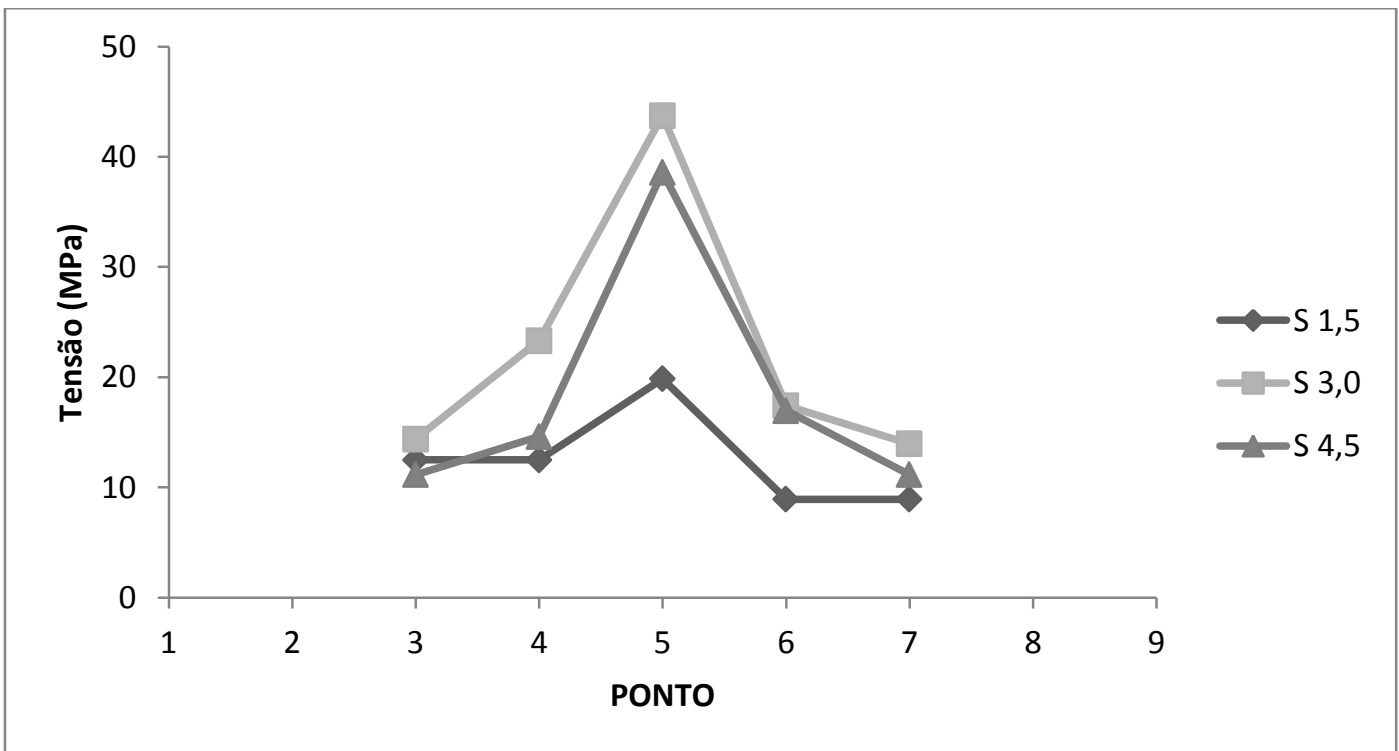

Figura 40 - Gráfico das tensões em cada ponto analisado no carregamento pontual central - S 1,5: pilar sólido e transmucoso de $1,5 \mathrm{~mm}$; S 3,0: pilar sólido e transmucoso de $3,0 \mathrm{~mm}$; S 4,5: pilar sólido e transmucoso de $4,5 \mathrm{~mm}$.

\subsection{Implante Isolado (Carregamento Distal)}

\subsubsection{Transmucoso de 1,5 mm (comparação entre pilar PP e S)}

As figuras 41 e 42 e a tabela 18 apresentam os resultados obtidos a partir do carregamento dos modelos com pilar PP e $S$ com transmucoso de 1,5 mm. Nos pontos 3, 4, 6 e 7 as maiores tensões estiveram no modelo com pilar PP, em 5 as 
tensões foram iguais nos diferentes modelos. Nas cristas ósseas peri-implantares mesial e distal, o pilar $S$ reduziu as tensões em $53 \%$ e $12 \%$ respectivamente.

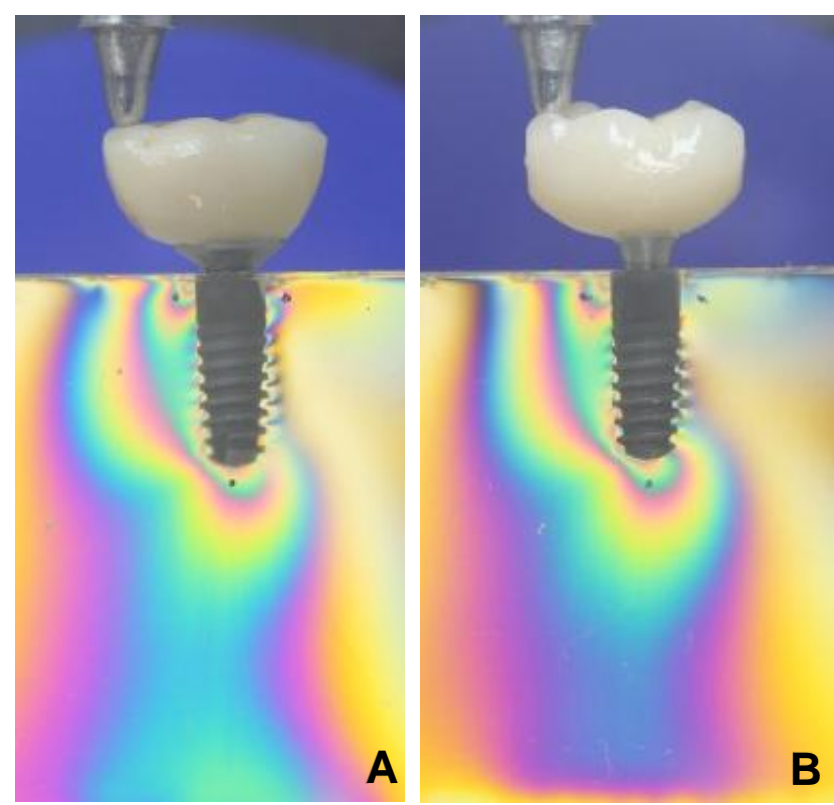

Figura 41 - Imagens fotoelásticas: A) pilar PP com transmucoso de $1,5 \mathrm{~mm}$; B) pilar $\mathrm{S}$ com transmucoso de $1,5 \mathrm{~mm}$.

Tabela 18 - Tensões incidentes nos pontos de 3 a 7 dos modelos fotoelásticos com pilar PP e $S$ de transmucoso de 1,5 $\mathrm{mm}$.

\begin{tabular}{ccc}
\hline \multirow{2}{*}{ Ponto } & \multicolumn{2}{c}{ Tensão (MPa) } \\
\cline { 2 - 3 } & PP 1,5 & S 1,5 \\
\hline 3 & 8,59 & 4,02 \\
4 & 8,59 & 4,02 \\
5 & 25,32 & 25,88 \\
6 & 37,81 & 33,46 \\
7 & 37,81 & 33,46 \\
\hline
\end{tabular}




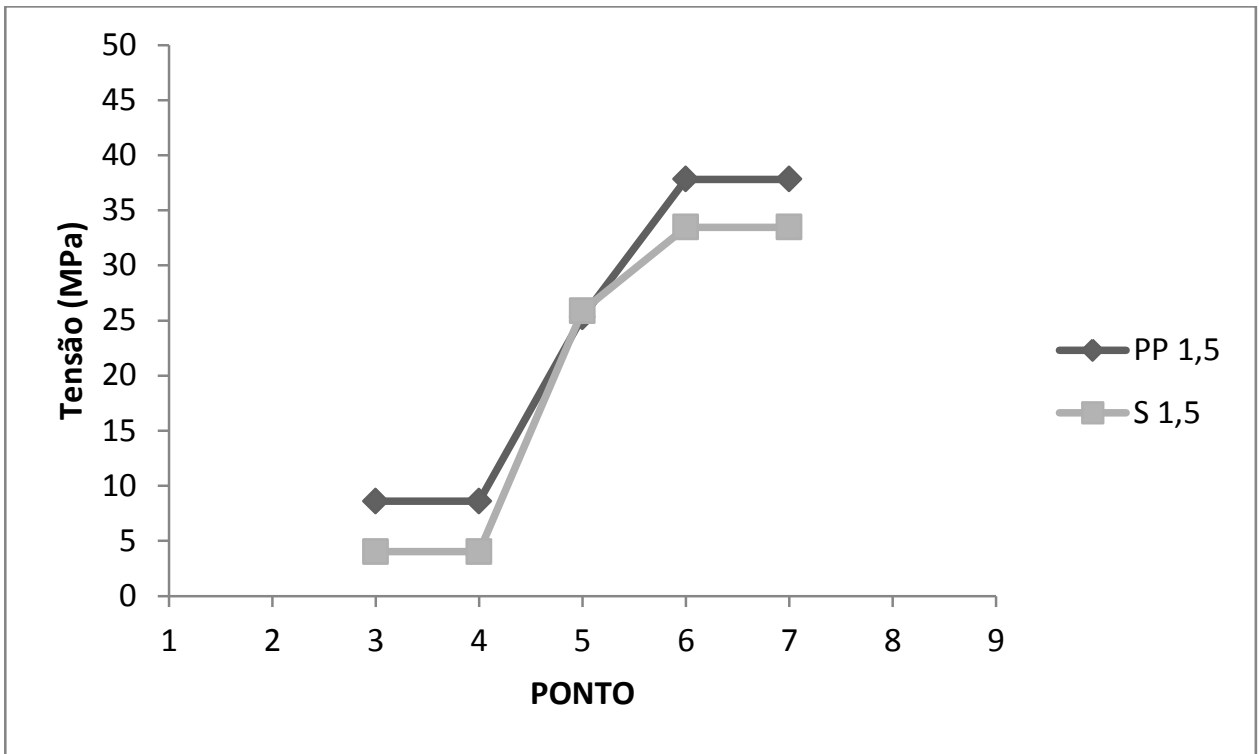

Figura 42 - Gráfico das tensões em cada ponto analisado no carregamento pontual distal - PP 1,5: pilar de parafuso passante e transmucoso de 1,5 mm; $\mathrm{S}$ 1,5: pilar sólido e transmucoso de $1,5 \mathrm{~mm}$.

\subsubsection{Transmucoso de 3,0 mm (comparação entre pilar PP e S)}

As figuras 43 e 44 e a tabela 19 apresentam os resultados obtidos a partir do carregamento dos modelos com pilar PP e S com transmucoso de 3,0 $\mathrm{mm}$. No ponto 3 a maior tensão foi no modelo com pilar S. Em 4 e 5 as tensões permaneceram iguais entre os pontos de mesma numeração. Nos pontos 6 e 7 as maiores tensões foram no modelo com pilar PP. Na crista óssea peri-implantar mesial, o pilar PP reduziu a tensão em $56 \%$. Na crista óssea peri-implantar distal, o pilar S diminuiu a tensão em $70 \%$. 


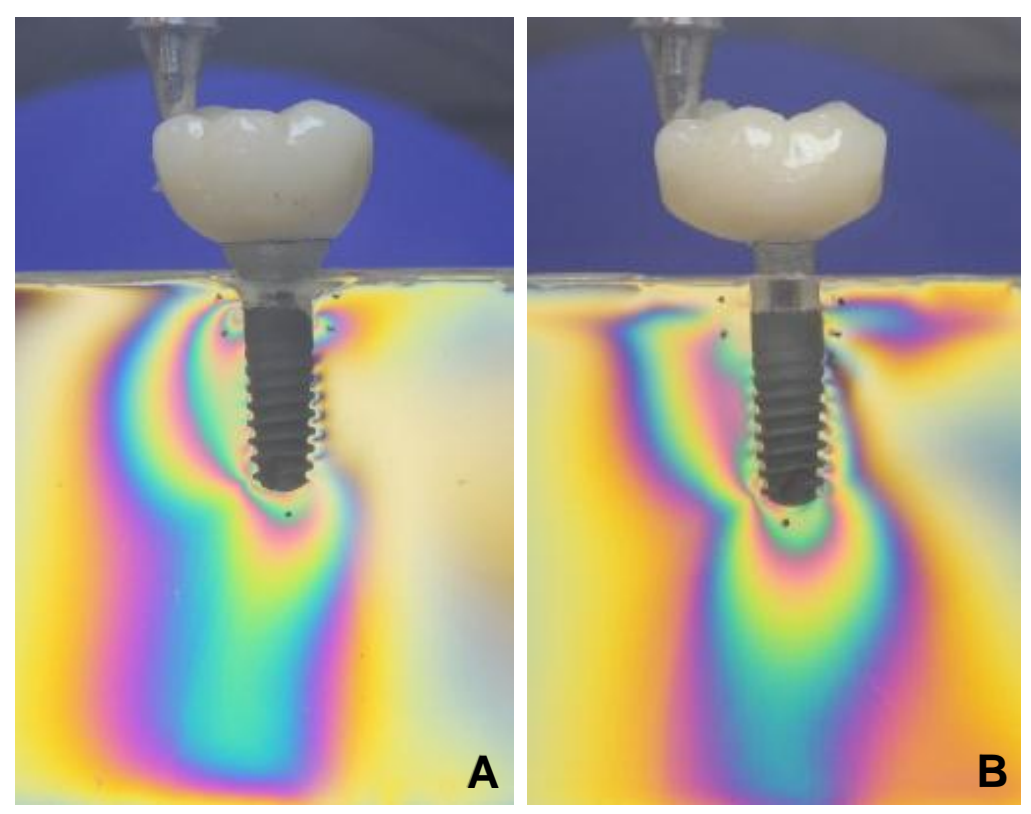

Figura 43 - Imagens fotoelásticas: A) pilar PP com transmucoso de $3,0 \mathrm{~mm}$; B) pilar $\mathrm{S}$ com transmucoso de $3,0 \mathrm{~mm}$.

Tabela 19 - Tensões incidentes nos pontos de 3 a 7 dos modelos fotoelásticos com pilar PP e S de transmucoso de 3,0 $\mathrm{mm}$.

\section{Tensão (MPa)}

\begin{tabular}{ccc} 
Ponto & PP 3,0 & S 3,0 \\
\hline $\mathbf{3}$ & 3,57 & 8,14 \\
$\mathbf{4}$ & 11,49 & 12,16 \\
$\mathbf{5}$ & 26,88 & 29,11 \\
$\mathbf{6}$ & 34,80 & 22,64 \\
$\mathbf{7}$ & 21,53 & 6,36 \\
\hline
\end{tabular}




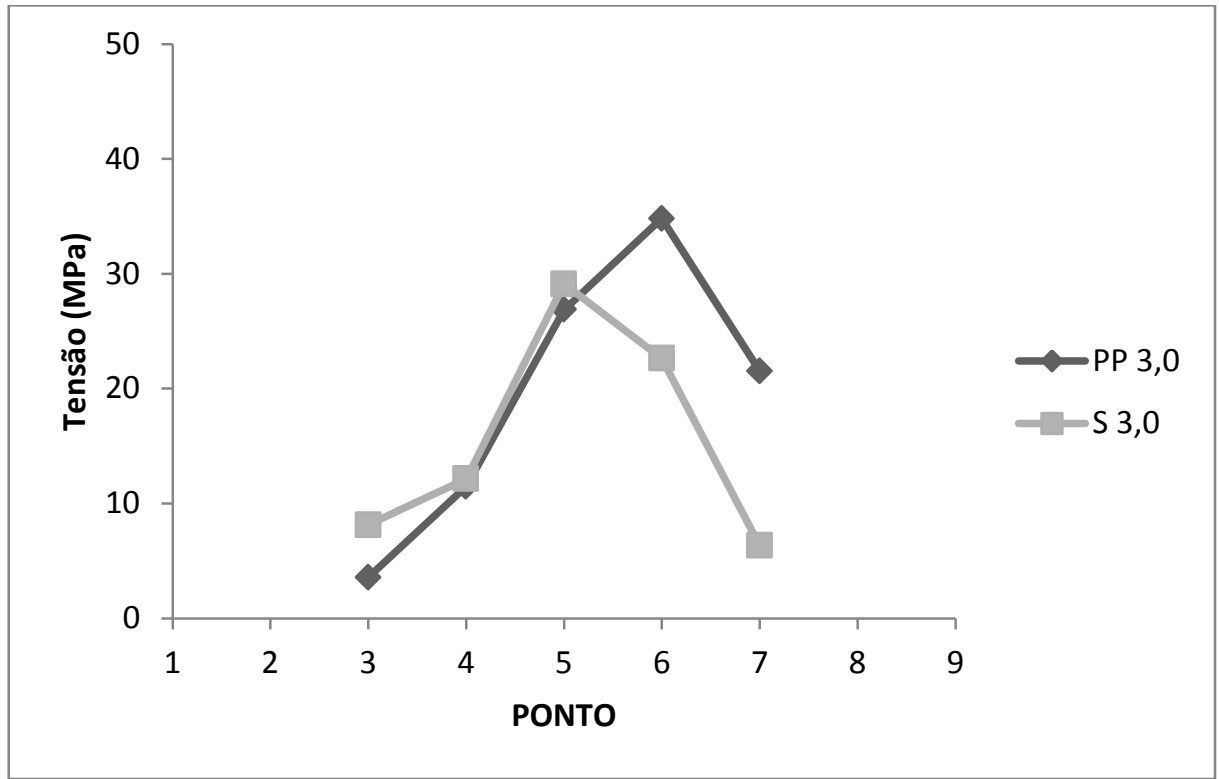

Figura 44 - Gráfico das tensões em cada ponto analisado no carregamento pontual distal - PP 3,0: pilar de parafuso passante e transmucoso de 3,0 mm; S 3,0: pilar sólido e transmucoso de 3,0 $\mathrm{mm}$.

\subsubsection{Transmucoso de 4,5 mm (comparação entre pilar PP e S)}

As figuras 45 e 46 e a tabela 20 apresentam os resultados obtidos a partir do carregamento dos modelos com pilar PP e $S$ com transmucoso de 4,5 mm. Nos pontos 3, 4, 5 e 6 as maiores tensões estiveram no modelo com pilar S. Em 7 a maior tensão foi no modelo com pilar PP. Na crista óssea peri-implantar mesial e no ápice do implante, o pilar PP reduziu as tensões em $92 \%$ e $28 \%$ respectivamente. Na crista óssea peri-implantar distal, o pilar S diminuiu a tensão em $60 \%$. 


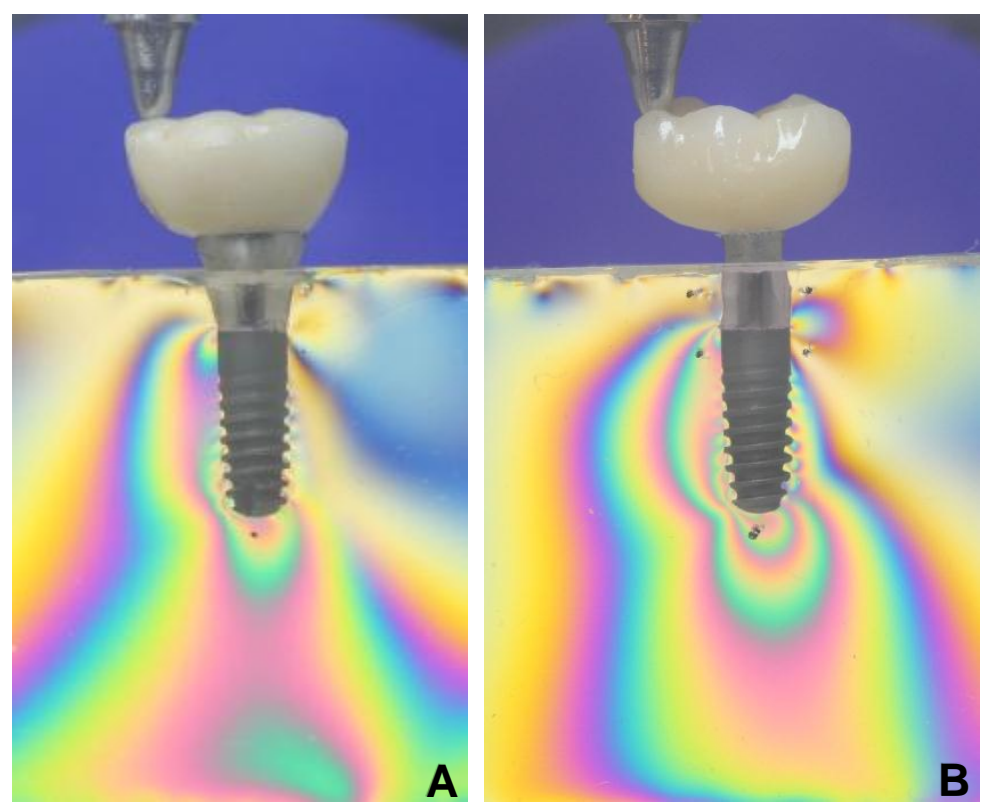

Figura 45 - Imagens fotoelásticas: A) pilar PP com transmucoso de $4,5 \mathrm{~mm}$; B) pilar $\mathrm{S}$ com transmucoso de 4,5 $\mathrm{mm}$.

Tabela 20 - Tensões incidentes nos pontos de 3 a 7 dos modelos fotoelásticos com pilar PP e S de transmucoso de $4,5 \mathrm{~mm}$.

Tensão (MPa)

\begin{tabular}{ccc} 
Ponto & PP 4,5 & S 4,5 \\
\hline $\mathbf{3}$ & 0,67 & 8,03 \\
$\mathbf{4}$ & 0,89 & 8,03 \\
$\mathbf{5}$ & 31,79 & 44,28 \\
$\mathbf{6}$ & 23,42 & 28,33 \\
$\mathbf{7}$ & 4,68 & 1,90 \\
\hline
\end{tabular}




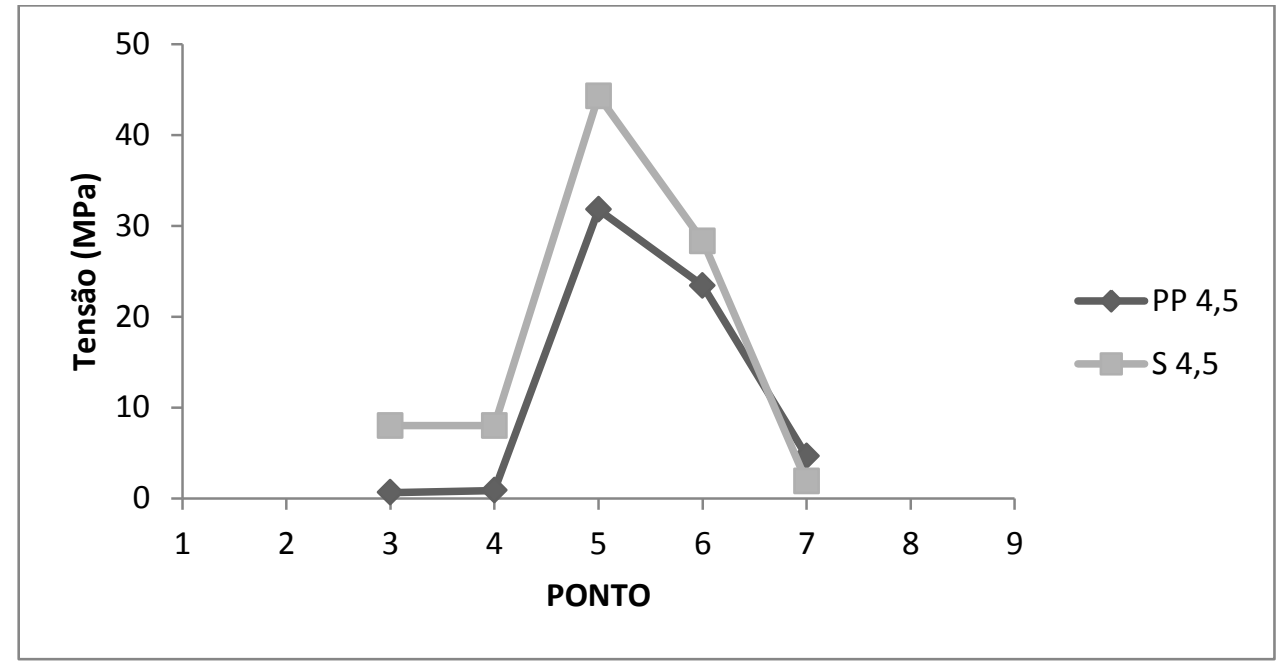

Figura 46 - Gráfico das tensões em cada ponto analisado no carregamento pontual distal - PP 4,5: pilar de parafuso passante e transmucoso de 4,5 mm; $\mathrm{S}$ 4,5: pilar sólido e transmucoso de $4,5 \mathrm{~mm}$.

\subsubsection{Pilar PP (transmucoso de 1,5 mm, 3,0 mm e 4,5 mm)}

A tabela 21 e a figura 47 apresentam os resultados obtidos a partir do carregamento dos modelos com pilar PP com alturas de transmucoso de $1,5 \mathrm{~mm}$, 3,0 $\mathrm{mm}$ e 4,5 mm. Nos pontos 3, 6 e 7 as maiores tensões estiveram no modelo com implante equicristal. Em 4 a maior tensão foi no modelo com implante infraósseo a $1,5 \mathrm{~mm}$. No ponto 5 a tensão mais alta esteve no modelo com implante infraósseo a $3,0 \mathrm{~mm}$. Na crista óssea peri-implantar mesial, os implantes infraósseo a 1,5 mm e a $3,0 \mathrm{~mm}$ reduziram as tensões em $58 \%$ e $92 \%$ respectivamente. No ápice do implante a tensão foi diminuída em $20 \%$ quando implantes equicristal e infraósseo a $1,5 \mathrm{~mm}$ foram utilizados. Na crista óssea peri-implantar distal, os implantes infraósseo a $1,5 \mathrm{~mm}$ e a $3,0 \mathrm{~mm}$ reduziram as tensões em $43 \%$ e $88 \%$ respectivamente. 
Tabela 21 - Tensões incidentes nos pontos de 3 a 7 dos modelos fotoelásticos com pilar PP de transmucoso de $1,5 \mathrm{~mm}, 3,0 \mathrm{~mm}$ e $4,5 \mathrm{~mm}$.

Tensão (MPa)

\begin{tabular}{cccc} 
Ponto & PP 1,5 & PP 3,0 & PP 4,5 \\
\hline $\mathbf{3}$ & 8,59 & 3,57 & 0,67 \\
$\mathbf{4}$ & 8,59 & 11,49 & 0,89 \\
$\mathbf{5}$ & 25,32 & 26,88 & 31,79 \\
$\mathbf{6}$ & 37,81 & 34,80 & 23,42 \\
$\mathbf{7}$ & 37,81 & 21,53 & 4,68 \\
\hline
\end{tabular}

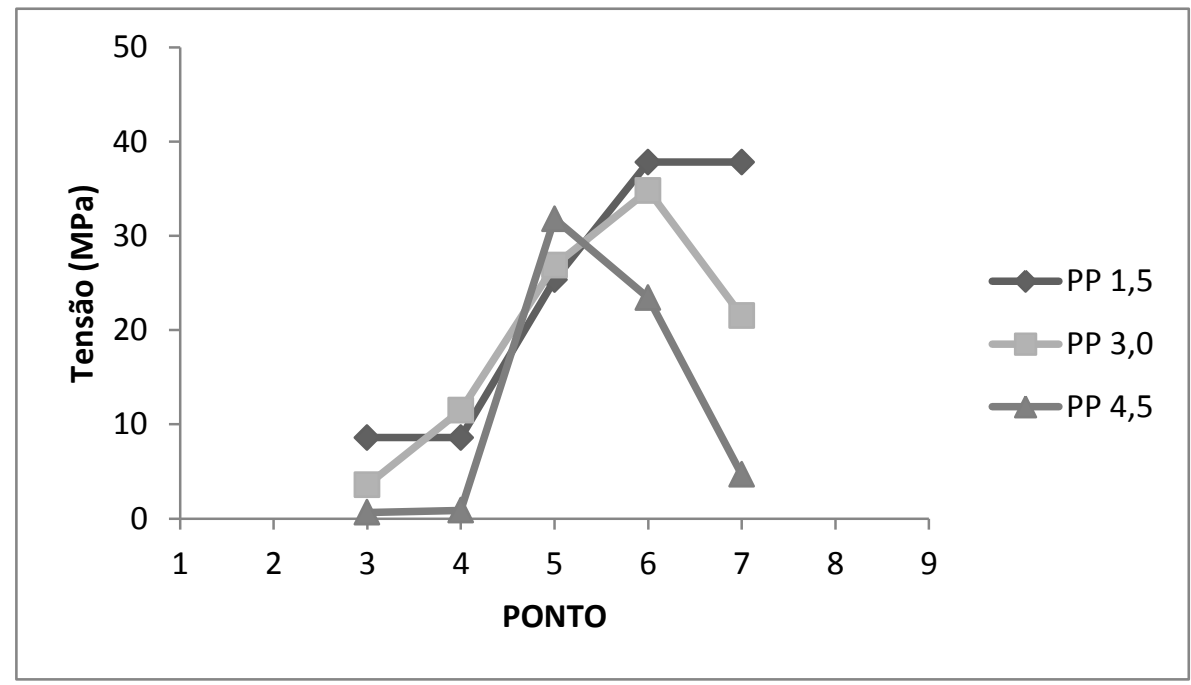

Figura 47 - Gráfico das tensões em cada ponto analisado no carregamento pontual distal - PP 1,5: pilar de parafuso passante e transmucoso de 1,5 $\mathrm{mm}$. PP 3,0: pilar de parafuso passante e transmucoso de 3,0 mm. PP 4,5: pilar de parafuso passante e transmucoso de $4,5 \mathrm{~mm}$.

\subsubsection{Pilar S (transmucoso de $1,5 \mathrm{~mm}, 3,0 \mathrm{~mm}$ e $4,5 \mathrm{~mm}$ )}

A tabela 22 e a figura 48 apresentam os resultados obtidos a partir do carregamento dos modelos com pilar $\mathrm{S}$ com alturas de transmucoso de $1,5 \mathrm{~mm}, 3,0$ $\mathrm{mm}$ e $4,5 \mathrm{~mm}$. No ponto 3 a maiores tensões estiveram nos modelos com implantes infraósseo, sendo que as mesmas possuíam valores iguais. No ponto 4 a tensão mais elevada foi no modelo com implante infraósseo a 1,5 mm. Em 5 a maior tensão esteve no modelo com implante infraósseo a 3,0 mm. Nos pontos 6 e 7 as maiores 
tensões foram no modelo com implante equicristal. Na crista óssea peri-implantar mesial, o implante equicristal reduziu a tensão em $51 \%$. No ápice do implante, os implantes equicristal e infraósseo a 1,5 mm diminuíram a tensão em $42 \%$ e $34 \%$ respectivamente. Na crista óssea peri-implantar distal, os implantes infraósseo a 1,5 $\mathrm{mm}$ e a $3,0 \mathrm{~mm}$ reduziram as tensões em $81 \%$ e $94 \%$ respectivamente.

Tabela 22 - Tensões incidentes nos pontos de 3 a 7 dos modelos fotoelásticos com pilar $S$ de transmucoso de $1,5 \mathrm{~mm}, 3,0 \mathrm{~mm}$ e $4,5 \mathrm{~mm}$.

\begin{tabular}{cccc}
\hline \multirow{2}{*}{ Ponto } & \multicolumn{3}{c}{ Tensão (MPa) } \\
\cline { 2 - 4 } & $\mathbf{S ~ 1 , 5}$ & $\mathbf{S ~ 3 , 0}$ & $\mathbf{S 4 , 5}$ \\
\hline $\mathbf{3}$ & 4,02 & 8,14 & 8,03 \\
$\mathbf{4}$ & 4,02 & 12,16 & 8,03 \\
$\mathbf{5}$ & 25,88 & 29,11 & 44,28 \\
$\mathbf{6}$ & 33,46 & 22,64 & 28,33 \\
$\mathbf{7}$ & 33,46 & 6,36 & 1,90 \\
\hline
\end{tabular}

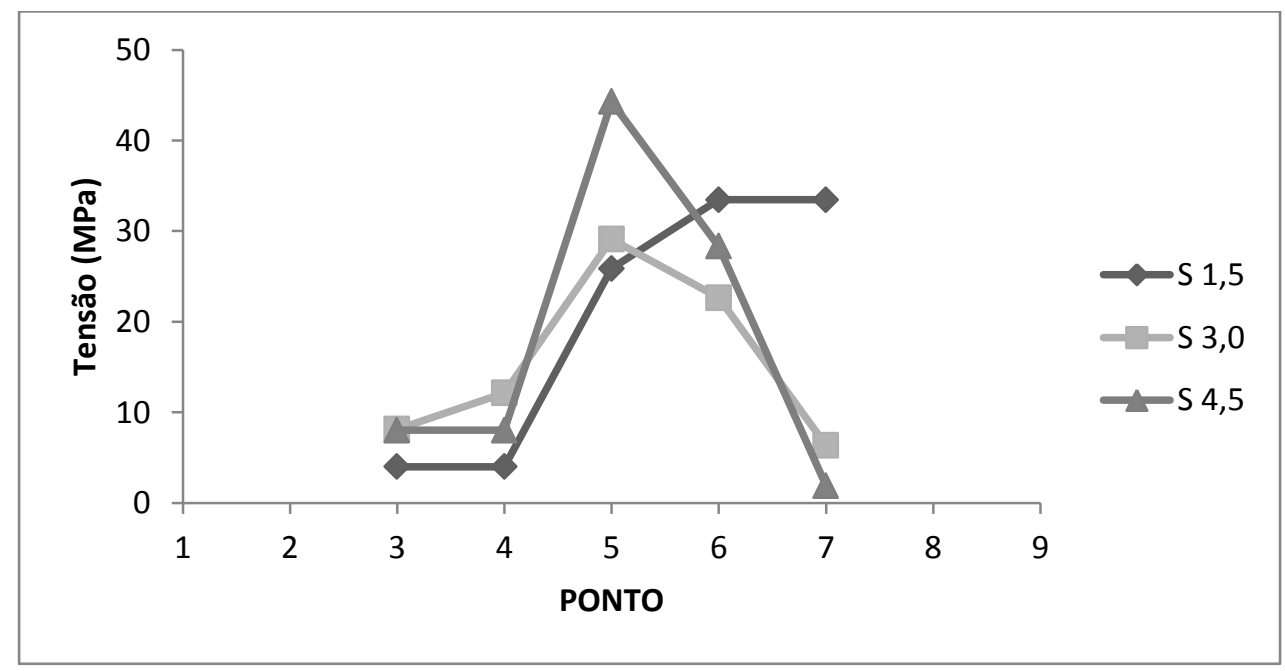

Figura 48 - Gráfico das tensões em cada ponto analisado no carregamento pontual distal - S 1,5: pilar sólido e transmucoso de 1,5 mm; S 3,0: pilar sólido e transmucoso de $3,0 \mathrm{~mm}$; $S$ 4,5: pilar sólido e transmucoso de $4,5 \mathrm{~mm}$. 
6. DISCUSSÃO 
A osseointegração foi definida como a ancoragem do implante ao leito ósseo receptor, com a formação de tecido ósseo sobre a superfície do implante e com a ausência de tecido conjuntivo interpondo-os (ALBREKTSSON et al., 1981). conceito biológico e mecânico fundamentam a obtenção e a manutenção da osseointegração (ABUHUSSEIN et al., 2010). O carregamento oclusal adequado proporciona a remodelação óssea peri-implantar (ABUHUSSEIN et al., 2010). Em contrapartida, a sobrecarga oclusal desencadeia a osteoclastogênese (HANSSON e WERKE, 2003). Na região cervical peri-implantar, a prevalência da reabsorção frente à neoformação óssea se manifesta com o surgimento de defeitos ósseos (PRENDERGAST e HUISKES, 1996), os quais são ocupados por microrganismos e tecido fibroso em breve espaço de tempo (MISCH et al., 2001).

Isidor (1997) propôs a instalação de implantes em macacos, após seis meses do procedimento cirúrgico as próteses foram confeccionadas. O objetivo principal do estudo foi avaliar a influência da posição supra-oclusal das coroas na osseointegração consolidada dos implantes. A sobrecarga gerada em tal circunstância possibilitou ao autor observar com dezoito meses de carregamento, que a maioria dos implantes apresentava sinais clínicos, radiográficos e histológicos de perda parcial ou total da osseointegração. Outros implantes não tiveram a sobrecarga induzida, o intuito foi averiguar as consequências do acúmulo de placa bacteriana na osseointegração. Os resultados mostraram que ao contrário da sobrecarga a placa bacteriana não motivou a perda da osseointegração, apenas causou reabsorções ósseas localizadas.

Com o propósito de tornar a conexão ao implante e a confecção das próteses ações de simples execução, diferentes desenhos de pilares protéticos podem ser selecionados (BABBUSH et al., 1987; RANGERT et al., 1991). Os pilares protéticos cônicos possuem dois mecanismos distintos para estabelecer conexão ao implante (PERRIARD et al., 2002; NORTON, 1999). Os pilares sólidos contêm na extremidade inferior roscas usinadas, já os pilares de parafuso passante contam com o auxílio de um parafuso que não compõem o corpo do pilar. A preferência por um determinado pilar em detrimento a outro, depende de inúmeros fatores (PINTINHA et al., 2013). Dentre eles, a natureza dos procedimentos clínicos e laboratoriais a ser realizados, a posição ocupada pelo implante, uma vez que pode estar relacionada à áreas de demanda estética e por último as evidências científicas que demonstram a confiabilidade do sistema. 
Para o presente estudo, a fotoelasticidade foi o método eleito para mensurar a distribuição de tensões em modelos fotoelásticos com implantes osseointegráveis sob carregamento. A fotoelasticidade permite que os resultados obtidos a partir de seus recursos sejam confiáveis (KINNI et al., 1987; GUICHET et al., 2000), estabelecendo simultânea congruência aos resultados alcançados em estudos in vivo (BRODSKY et al., 1975). Para que os achados sejam verdadeiros são imprescindíveis os cuidados durante as fases prévias a análise, o que implica em não exceder o limite elástico do material fotoelástico, posicionar corretamente os modelos para aplicação da carga, determinar contornos adequados aos modelos e se certificar da ausência de tensões prévias ao carregamento (MAHLER e PEYTON, 1955; CAMPOS JR. et al., 1986).

As análises fotoelásticas dos modelos com implantes isolados permitiram avaliar as caracteristicas dos pilares e do implante sem que houvesse outros elementos a serem considerados. O carregamento pontual central dos pilares $\mathrm{S}$ e PP com transmucoso de 4,5 $\mathrm{mm}$ revelou que ambos geraram valores similares de tensões na crista óssea peri-implantar. As principais diferenças encontradas na dissipação das cargas centralizadas estiveram no transmucoso de 1,5 mm e de 3,0 $\mathrm{mm}$, com melhor performance para S e PP respectivamente. Akça et al. (2003) avaliaram pelo método de elementos finitos com análise não-linear, implantes de conexão cônica conectados a pilares sólidos. No carregamento vertical, as tensões se localizaram na interface entre o implante e o pilar protético, com maiores tensões no pilar e menores na superfície externa do implante próxima à plataforma. Tensões reduzidas também foram observadas nas roscas do pilar, permanecendo as maiores tensões no segmento plano anterior às roscas.

Os pilares S e PP submetidos ao carregamento pontual distal tiveram desequilíbrio mesio-distal na distribuição das tensões, o qual ocorreu quando os pilares dispunham da altura de transmucoso de $1,5 \mathrm{~mm}$. A distalização do contato oclusal gerou na crista óssea peri-implantar distal, tensões superiores às visualizadas na crista óssea peri-implantar mesial, em decorrência do braço de alavanca formado na interface de conexão do implante com o pilar protético. Torres (2008) utilizou a fotoelasticidade para avaliar a dissipação de forças no entorno de implantes reabilitados com próteses individuais e ferulizadas. O carregamento pontual distal dos implantes com próteses individuais comprovou a incidência de tensões maiores na crista óssea peri-implantar distal do que na crista óssea peri- 
implantar mesial. Quanto ao desempenho dos pilares ao carregamento proposto pelo presente estudo, os melhores resultados para o transmucoso de $1,5 \mathrm{~mm}$ e de $3,0 \mathrm{~mm}$ se vincularam ao pilar $\mathrm{S}$, com redução da tensão na crista óssea periimplantar. Para o transmucoso de 4,5 mm, o pilar PP teve maior eficiência.

Os tratamentos implanto-protéticos podem estar relacionados com o restabelecimento de unidades dentárias que ocupavam os extremos das arcadas. No presente estudo houve diferenças significativas na distribuição de tensões ao utilizar os pilares S e PP com diferentes alturas de transmucoso em extremidades livres. Com a altura de $1,5 \mathrm{~mm}$, o melhor desempenho foi o do pilar $\mathrm{S}$, para as demais medidas os resultados foram favoráveis ao pilar PP. Os resultados com o transmucoso de $3,0 \mathrm{~mm}$ e de $4,5 \mathrm{~mm}$ podem ser justificados pelo aumento da proporção coroa/implante. Neste caso o maior diâmetro da base de assentamento da prótese do pilar PP, o capacitou a absorver mais tensões. Entretanto, o diâmetro inferior da base de assentamento da prótese do pilar $\mathrm{S}$ permitiu que grande parte das tensões ficassem restristas a ele, quando a interface de conexão estava em osso cortical.

Reabilitações unitárias com implantes osseointegráveis em extremidades livres definem apenas contatos proximais mesiais. No presente estudo, foram notórias as alterações na distribuição de tensão à crista óssea peri-implantar distal após a adição do segundo molar, o que possibilitou a diminuição da tensão em relação à encontrada quando apenas do contato proximal com o segundo pré-molar. Esses resultados corroboram aos achados de Tiossi (2009), que propôs a avaliação de diferentes planejamentos implanto-protéticos a partir de modelos fotoelásticos. Segundo o autor, a presença do segundo molar implicou em uma distribuição mais uniforme das tensões às coroas e aos dentes do que quando de sua ausência.

A existência de dente posterior à coroa protética beneficiou o desempenho mecânico do pilar S frente ao PP, independentemente da altura do transmucoso. O pilar $S$ tem em sua base de assentamento da prótese um diâmetro de 3,3 mm, dimensão inferior ao do pilar PP. O menor diâmetro ocasionou o direcionamento das tensões para o longo eixo do implante. Já o pilar PP por ter um diâmetro de 4,5 mm na base de assentamento da prótese motivou o surgimento de um braço de alavanca, causando o aumento das tensões na crista óssea peri-implantar. Estes resultados contrapõem os achados de Norton (2000) obtidos a partir do carregamento de pilares protéticos sólidos e de parafuso passante. O pilar sólido 
apresentou maiores deformações em relação ao de parafuso passante, para o autor a rigidez do pilar sólido representou um risco de sobrecarga ao tecido ósseo.

Com o posicionamento infraósseo da plataforma do implante criaram-se condições favoráveis para a formação e a manutenção de picos de crista óssea nas regiões interimplantares (NOVAES et al., 2009). Porém, tal fato somente ocorreu após o desenvolvimento de implantes com desenho cônico, roscas progressivas e plataformas ásperas (DEGIDI et al., 2008; WENG et al., 2008; DEGIDI et al., 2010; ROMANOS et al., 2010). Nos modelos fotoelásticos com implante isolado sob carregamento pontual central, os implantes infraósseo conectados ao pilar PP geraram menor tensão. No carregamento pontual distal, o implante infraósseo a 3 $\mathrm{mm}$ conectado aos pilares PP e $\mathrm{S}$ reduziram as tensões na crista óssea periimplantar. Esses achados podem justificar o contato firmado entre o tecido ósseo e a superfície metálica do pilar protético em determinadas reabilitações com implantes de conexão cônica na posição infraóssea (DEGIDI et al., 2011).

Luo et al. (2012) reabilitaram pacientes parcialmente desdentados com implantes de conexão cônica em áreas posteriores de mandíbula, o acompanhamento clínico e radiográfico foi realizado entre trinta e seis e oitenta e cinco meses. Dependendo das dimensões do rebordo remanescente, a plataforma dos implantes ocupou diferentes profundidades. Os exames por imagem foram usados para mensurar a reabsorção óssea ocorrida nos implantes no período compreendido entre a instalação e a função. As avaliações das medidas obtidas possibilitaram aos autores definir que os implantes infraósseo apresentavam maiores chances de manter o tecido ósseo estável. Os resultados relatados anteriormente podem advir dos achados do presente estudo, uma vez que implantes cônicos na posição infraóssea se caracterizam por conservar as tensões exacerbadas distantes do osso cortical.

A exceção em meio aos implantes avaliados isoladamente sob carregamento pontual central foi o do implante equicristal que permaneceu conectado ao pilar $S$. Nesta circunstância as tensões no tecido ósseo subjacente foram menores que as encontradas nos implantes infraósseo. O que está de acordo com as indicações de planejamento propostas por Chu et al. (2011). Segundo os autores, os implantes equicristais devem ser uma opção quando o osso cortical tiver espessuras menores ou iguais a 2,5 mm, caso ultrapasse este valor o recomendado é adotar um posicionamento moderadamente infraósseo para o implante. Jung et al. (2008) em estudo com cães constataram que implantes de conexão cônica na posição 
equicristal causaram menor reabsorção óssea que implantes infraósseo instalados em sítios adjacentes.

Bozkaya et al. (2004) utilizaram a análise de elementos finitos para determinar que implantes osseointegrados submetidos a carregamento apresentaram alta incidência de tensão no osso cortical. As tensões elevadas na crista óssea periimplantar foram relacionadas ao processo de reabsorção óssea ( $\mathrm{OH}$ et al., 2002). Entretanto, com a mudança da plataforma do implante de conexão cônica para a posição infraóssea, a reabsorção óssea cristal foi reduzida (TODESCAN et al., 2002; WELANDER et al., 2009). As análises fotoelásticas realizadas no presente estudo demonstraram que a posição infraóssea da plataforma do implante alterou os locais de concentração das tensões, transferindo-as do osso cortical para o medular. O que foi extremamente relevante se considerado que o trabeculado do osso medular apresenta maior resistência e flexibilidade, assim como uma capacidade de absorção de stress funcional superior ao do osso cortical (MORRIS et al., 2004).

Pellizzer et al. (2014) por meio da fotoelasticidade avaliaram cinco sistemas de implantes com variados tipos de conexão protética. Após o carregamento axial, os autores concluíram que as principais diferenças entre os sistemas na distribuição das tensões aconteceram no terço cervical e apical dos implantes. Como consequência do uso de implantes com diversos desenhos e tipos de conexões protéticas, além da existência ou não de roscas até a plataforma protética. Ao final, o melhor desempenho biomecânico foi o dos implantes com conexão cônica, induzindo menores tensões à crista óssea peri-implantar. De acordo com os achados do atual estudo, pode-se acrescentar aos itens elencados por Pellizzer et al. (2014) como de influência na destruição das tensões, a profundidade do implante na crista óssea.

Nas extremidades livres, os implantes infraósseo a $1,5 \mathrm{~mm}$ e a 3,0 mm conectados aos pilares S e PP respectivamente melhoraram a distribuição das tensões. O que justifica os relatos de Donovan et al. (2010) que reabilitaram 50 pacientes parcialmente edêntulos com implantes de conexão cônica na posição infraóssea. Em média as plataformas protéticas dos implantes estavam a 1,37 mm e a 1,28 $\mathrm{mm}$ do pico ósseo interproximal mesial e distal respectivamente. Com doze meses da instalação dos implantes, a reabsorção óssea média correspondeu a $0,11 \mathrm{~mm}$ e em $69 \%$ dos implantes o tecido ósseo contatava a plataforma protética. Para a situação na qual a coroa protética estava entre réplicas dentais, o implante 
infraósseo a 3,0 mm conectado ao pilar PP e o implante equicristal conectado ao pilar $S$ reduziram as tensões na crista óssea peri-implantar. 
7. CONCLUSÃO 
Com base nos resultados das análises fotoelásticas e considerando as limitações impostas pela metodologia, pode-se concluir que:

1. Em extremidades livres o pilar de parafuso passante conectado a implantes infraósseo promoveu uma melhor distribuição de tensões que o pilar sólido.

2. Em áreas interdentais o pilar sólido foi mais eficiente na distribuição de tensões que o pilar de parafuso passante.

3. Em extremidades livres o posicionamento infraósseo da plataforma do implante implicou em menores tensões à crista óssea peri-implantar.

4. Em áreas interdentais, o implante equicristal conectado ao pilar sólido e o implante infraósseo a 3,0 mm conectado ao pilar de parafuso passante induziram menores tensões na crista óssea peri-implantar. 
REFERÊNCIAS 
Abuhussein $\mathrm{H}$, Pagni G, Rebaudi A, Wang HL. The effect of thread pattern upon implant osseointegration. Clin Oral Implants Res. 2010 Fev;21(2):129-36.

Adell R, Eriksson B, Lekholm U, Brånemark PI, Jemt T. A long-term follow-up study of osseointegrated implants in the treatment of totally edentulous jaws. Int $\mathrm{J}$ Oral Maxillofac Implants. 1990;5(4):347-59.

Aguiar Jr FA. Análise fotoelástica das tensões geradas por coroas unitárias sobre implantes adjacentes na região posterior da mandibula. Efeito de sistemas de retenção e materiais de revestimento estético [dissertação]. Ribeirão Preto: Faculdade de Odontologia de Ribeirão Preto, Universidade de São Paulo, 2009.

Akça K, Çehreli MC, Iplikçioğlu H. Evaluation of the mechanical characteristics of the implant-abutment complex of a reduced-diameter morse-taper implant. A nonlinear finite element stress analysis. Clin Oral Implants Res. 2003 Aug;14(4):444-54.

Albrektsson T, Brånemark PI, Hansson HA, Lindström J. Osseointegrated titanium implants. Requirements for ensuring a longlasting, direct bone-to-implant anchorage in man. Acta Orthop Scand. 1981;52(2):155-70.

Albrektsson T, Zarb G, Worthington P, Eriksson AR. The long-term efficacy of currently used dental implants: a review and proposed criteria of success. Int $\mathrm{J}$ Oral Maxillofac Implants. 1986;1(1):11-25.

Alves SV, Análise fotoelástica de implantes Cone-Morse posicionados ao nível e infraósseo na região posterior [dissertação]. Ribeirão Preto: Faculdade de Odontologia de Ribeirão Preto, Universidade de São Paulo; 2013.

Assenza B, Tripodi D, Scarano A, Perrotti V, Piattelli A, lezzi G, D'Ercole S. Bacterial leakage in implants with different implant- abutment connections: An in vitro study. J Periodontol. 2012 Apr; 83(4):491-7.

Asvanund P, Morgano SM. Photoelastic stress analysis of different prefabricated post-and-core materials. Dent Mater J. 2011;30(5):684-90.

Atieh MA, Ibrahim HM, Atieh $\mathrm{AH}$. Platform switching for marginal bone preservation around dental implants: a systematic review and meta-analysis. J Periodontol. 2010 Oct;81(10):1350-66.

Babbush CA, Kirsch A, Mentag PJ, Hill B. Intramobile cylinder (IMZ) two-stage osteointegrated implant system with the intramobile element (IME): Part 1. Its rationale and procedure for use. Int J Oral Maxillofac Implants. 1987;2(4):203-16.

Baggi L, Cappelloni I, Di Girolamo M, Maceri F, Vairo G. The influence of implant diameter and length on stress distribution of osseointegrated implants related to crestal bone geometry: a three dimensional finite element analysis. J Prosthet Dent. 2008 Dec;100(6):422-31.

Balfour A, O'Brien GR. Comparative study of antirotational single tooth abutments. J Prosthet Dent. 1995 Jan;73(1):36-43. 
Balshi TJ, Ekfeldt A, Stenberg T, Vrielinck L. Three-year evaluation of Branemark implants connected to angulated abutments. Int J Oral Maxillofac Implants. 1997 JanFeb;12(1):52-8.

Barros RR, Novaes AB Jr, Muglia VA, Lezzi G, Piattelli A. Influence of interimplant distances and placement depth on peri-implant bone remodeling of adjacent and immediately loaded Morse cone connection implants: A histomorphometric study in dogs. Clin Oral Implants Res. 2010 Apr1;21(4):371-8.

Becker W, Becker BE. Replacement of maxillary and mandibular molars with single endosseous implant restorations: a retrospective study. J Prosthet Dent. 1995 Jul;74 (1):51-5.

Bozkaya D, Müftü S. Mechanics of the tapered interference fit in dental implants. J Biomech. 2003 Nov;36(11):1649-1658.

Bozkaya D, Muftu S, Muftu A. Evaluation of load transfer characteristics of five different implants in compact bone at different load levels by finite element analysis. $J$ Prosthet Dent. 2004 Dez;92(6):523-30.

Brodsky JF, Caputo AA, Furstman LL. Root tipping: a photoelastic-histopathologic correlation. Am J Orthod. 1975 Jan;67(1):1-10.

Brunski JB. Biomechanics of dental implants. In: Block M, Kent JN, Guerra LR, editors. Implants in dentistry. 1st ed. Philadelphia: WB Saunders; 1997. p. 63-71.

Brunski JB. In vivo bone response to biomechanical loading at the bone dentalimplant interface. Adv. Dent Res. jun 1999;13: 99-119.

Buser D, Dula K, Belser L, Hirt HP, Berthold H. Localized ridge augmentation using guided bone regeneration. 1. Surgical procedure in the maxilla. Int J Periodontics Restorative Dent. 1993;13(1):29-45.

Campos Jr A. et al. A fotoelasticidade na pesquisa odontológica. Estomatol Cult. $1986 ; 16(1): 20-5$.

Caputo AA, Standlee JP. Biomechanics in clinical dentistry. Quintessence Publishing, Chicago. 1987;13-26.

Çehreli M, Duyck J, De Cooman M, Puers R, Naert I. Implant design and interface force transfer. A photoelastic and strain-gauge analysis. Clin Oral Implants Res. 2004a Apr;15(2):249-57.

Çehreli MC, Akça K, Iplikçioğlu H, Sahin S. Dynamic fatigue resistance of implantabutment junction in an internally notched morse-taper oral implant: Influence of abutment design. Clin Oral Implants Res. 2004b Aug;15(4):459-65.

Çehreli S, Özçırpıcı AA, Yılmaz A. Tilted orthodontic micro implants: a photoelastic stress analysis. Eur J Orthod. 2013 Oct;35(5):563-7. 
Chou CT, Morris HF, Ochi S, Walker L, DesRosiers D. AICRG, Part II: crestal bone loss associated with the Ankylos implant-loading to 36 months. J Oral Implantol. 2004;30(3):134-43.

Chou HY, Jagodnik JJ, Müftü S. Predictions of bone remodeling around dental implant Systems. J Biomech. 2008;41(6):1365-1373.

Chou HY, Jagodnik JJ, Müftü S. Biomechanical Evaluation of Subcrestal Placement of Dental Implants: In Vitro and Numerical Analyses. J Biomech. 2008;41(6):13651373.

Chu CM, Hsu JT, Fuh LJ, Huang HL. Biomechanical Evaluation of Subcrestal Placement of Dental Implants: In Vitro and Numerical Analyses. J Periodontol. 2011;82:302-310.

Cochran D. Implant therapy I. Ann Periodontol. 1996 Nov;1(1):707-91.

Creugers NH, Kreulen CM, Snoek PA, de Kanter RJ. A systematic review of singletooth restorations supported by implants. J Dent. 2000 May;28(4):209-17.

Degidi M, Lezzi G, Scarano A, Piattelli A. Immediately loaded titanium implant with a tissue-stabilizing/ maintaining design ("beyond platform switch") retrieved from man after 4 weeks: a histological and histomorphometrical evaluation. A case report. Clin Oral Implants Res. 2008 Mar;19(3):276-82.

Degidi M, Nardi D, Piattelli A. Prospective study with a 2-year follow-up on immediate implant loading in the edentulous mandible with a definitive restoration using intraoral welding. Clin Oral Implants Res. 2010 Apr; 21(4):379-85.

Degidi M, Perrotti V, Shibli JA, Novaes AB, Piattelli A, Lezzi G. Equicrestal and Subcrestal Dental Implants: A Histologic and Histomorphometric Evaluation of Nine Retrieved Human Implants. J Periodontol. 2011 May;82(5):708-15.

Dibart S, Warbington $\mathrm{H}$, Su MF, Skobe Z. In vitro evaluation of the implant abutment bacterial seal: the locking taper system. Int J Oral Maxillofac Implants. 2005 Set-Out; 20(5):732-7.

Ding TA, Woody RD, Higginbottom FL, Miller BH. Evaluation of the ITI Morse taper implant/abutment design with an internal modification. Int $\mathrm{J}$ Oral Maxillofac Implants. 2003 Nov-Dec;18(6):865-72.

Donovan R, Fetner A, Koutouzis T, Lundgren T. Crestal bone changes around implants with reduced abutment diameter placed non-submerged and at subcrestal positions: a 1-year radiographic evaluation. J Periodontol. 2010 Mar;81(3):428-34.

Döring K, Eisenmann E, Stiller M. Functional and esthetic considerations for single tooth Ankylos implant crowns: 8 years of clinical performance. J Oral Implantol. 2004;30(3):198-209. 
Ekfeldt A, Carlsson GE, Börjesson G. Clinical evaluations of single-tooth restorations supported by osseointegrated implants: a retrospective study. Int $\mathrm{J}$ Oral Maxillofac Implants. 1994 Mar-Apr;9(2):179-83.

Engelman M. Clinical decision making and treatment planning in osseointegration. Chicago: Quintessence; 1996. p. 82-5.

Ericsson I, Persson LG, Berglundh T, Marinello CP, Lindhe J, Klinge B. Different types of inflammatory reactions in peri-implant soft tissues. J Clin Periodontol. 1995 Mar;22(3):255-61.

French AA, Bowles CQ, Parham PL, Eick JD, Killoy WJ, Cobb CM. Comparison of peri-implant stresses transmitted by four commercially available osseointegrated implants. Int J Periodontics Restorative Dent. 1989;9(3):221-30.

Frost, HM. Skeletal structural adaptations to mechanical usage (satmu): redefining Wolff's law: the bone modeling problem. Anat Rec. 1990 Apr;226(4):403-13.

Fugazzotto PA. Success and failure rates of osseointegrated implants in function in regenerated bone for 72 to 133 months. Int J Oral Maxillofac Implants. 2005 JanFev;20(1):77-83.

Geng JP, Ma QS, Xu W, Tan KB, Liu GR. Finite element analysis of four thread form configurations in a stepped screw implant. J Oral Rehabil. 2004a Mar;31(3):233-9.

Geng JP, Xu DW, Tan KB, Liu GR. Finite element analysis of an osseointegrated stepped screw dental implant. J Oral Implantol. 2004b;30(4):223-33.

Goiato MC, Tonella BP, Ribeiro Pdo P, Ferraço R, Pellizzer EP. Methods used for assessing stresses in buccomaxillary prostheses photoelasticity, finite element and extensometry. J Craniofac Surg. 2009 Mar;20(2):561-4.

Goodacre CJ, Bernal G, Rungcharassaeng K, Kan JY. Clinical complications with implants and implant prostheses. J Prosthet Dent. 2003 Ago;90(2):121-32.

Guichet DL, Caputo AA, Choi H, Sorensen JA. Passivity of fit and marginal opening in screw-or cement-retained implant fixed partial denture designs. Int $\mathrm{J}$ Oral Maxillofac Implants. 2000 Mar-Apr;15(2):239-46.

Hämmerle $\mathrm{CH}$, Bragger U, Bürgin W, Lang NP. The effect of subcrestal placement of the polished surface of ITI implants on marginal soft and hard tissues. Clin Oral Implants Res. 1996 Jun;7(2):111-9.

Hansson S. Implant-abutment interface: Biomechanical study of flat top versus conical. Clin Implant Dent Relat Res. 2000;2(1):33-41.

Hansson S, Werke M. The implant thread as a retention element in cortical bone: The effect of thread size and thread profile: a finite element study. J Biomech. 2003 Sep;36(9):1247-1258. 
Hartman GA, Cochran DL. Initial implant position determines the magnitude of crestal bone remodeling. J Periodontol. 2004 Apr;75(4):572-7.

Haas R, Mensdorff-Pouilly N, Mailath G, Watzek G. Branemark single tooth implants: a preliminary report of 76 implants. J Prosthet Dent. 1995 Mar;73(3):274-9.

Hermann JS, Cochran DL, Nummikoski PV, Buser D. Crestal bone changes around titanium implants. A radiographic evaluation of unloaded nonsubmerged and submerged implants in the canine mandible. J Periodontol. 1997 Nov;68(11):11171130.

Hermann JS, Schoolfield JD, Schenk RK, Buser D, Cochran DL. Influence of the size of the microgap on crestal bone changes around titanium implants. A histometric evaluation of unloaded non submerged implants in the canine mandible. $J$ Periodontol. 2001 Oct;72(10):1372-83.

Hermann JS, Buser D, Schenk RK, Cochran DL. Crestal bone changes around titanium implants. A histometric evaluation of unloaded non-submerged and submerged implants in the canine mandible. J Periodontol. 2000 Sep;71(9):14121424.

Holmgren EP, Seckinger RJ, Kilgren LM, Mante F. Evaluating parameters of osseointegrated dental implants using finite element analysis - a two dimensional comparative study examining the effects of implant diameter, implant shape, and load direction. J Oral Implantol. 1998;24(2):80-8.

Huang B, Meng H, Zhu W, Witek L, Tovar N, Coelho PG. Influence of placement depth on bone remodeling around tapered internal connection implants: a histologic study in dogs. Clin Oral Implants Res. 2015 Aug;26(8):942-9.

Hürzeler M, Fickl S, Zuhr O, Wachtel HC. Peri-implant bone level around implants with platform-switched abutments: preliminary data from a prospective study. J Oral Maxillofac Surg. 2007 Jul;65(7 Suppl 1):33-9.

Isidor F. Histological evaluation of peri-implant bone at implants subjected to occlusal overload or plaque accumulation. Clin Oral Implants Res. 1997 Feb;8(1):1-9.

Jansen VK, Conrads L, Richter EJ. Microbial leakage and marginal fit of the implant abutment interface. Int J Oral Maxillofac Implants. 1997 Jul-Ago;12(4):527-40.

Jemt T, Laney WR, Harris D, Henry PJ, Krogh PH Jr, Polizzi G, Zarb GA, Herrmann I. Osseointegrated implants for single tooth replacement: a 1-years report from a multicenter prospective study. Int J Oral Maxillofac Implants. 1991;6(1):29-36.

Jung RE, Holderegger C, Sailer I, Khraisat A, Suter A, Hämmerle CH. The effect of all-ceramic and porcelain-fused-to-metal restorations on marginal peri-implant soft tissue color: a randomized controlled clinical trial. Int $\mathrm{J}$ Periodontics Restorative Dent. 2008a Aug;28(4):357-65. 
Jung RE, Jones AA, Higginbottom FL, Wilson TG, Schoolfield J, Buser D, Hämmerle $\mathrm{CH}$, Cochran DL. The influence of non- matching implant and abutment diameters on radiographic crestal bone levels in dogs. J Periodontol. 2008b Feb;79(2):260-70.

Keith SE, Miller BH, Woody RD, Higginbottom FL. Marginal discrepancy of screw retained and cemented metal ceramic crowns on implant abutments. Int $\mathrm{J}$ Oral Maxillofac Implants. 1999 May-Jun;14(3):369-78.

Khraisat A, Stegaroiu R, Nomura S, Miyakawa O. Fatigue resistance of two implant/abutment joint designs. J Prosthet Dent. 2002 Dec;88(6):604-10.

Kinni ME, Hokama SN, Caputo AA. Force transfer by osseointegration implant devices . Int J Oral Maxillofac Implants. 1987;2(1):11-4.

Koutouzis T, Carteira S, Calderon N, Lundgren T. Bacterial colonization of the implant-abutment interface using an in vitro dynamic loading model. J Periodontol. 2011 Apr; 82(4):613-8.

Lang NP, Salvi G. Implants in restorative dentistry. In: Lindhe J, Lang NP, Karring T. Eds. Clinical Periodontology and Implant Dentistry. 5th edition. Denmark: Blackwell Munksgaard. 2008; p.1138-1145.

Lazzara RJ, Porter SS. Platform switching: a new concept in implant dentistry for controlling postrestorative crestal bone levels. Int $\mathrm{J}$ Periodontics Restorative Dent. 2006 Feb;26(1):9-17.

Leutert CR, Stawarczyk B, Truninger TC, Hämmerle CH, Sailer I. Bending moments and types of failure of zirconia and titanium abutments with internal implant-abutment connections: a laboratory study. Int J Oral Implants Maxillofac. 2012 MayJun;27(3):505-12.

Levine RA, Clem DS, Wilson TG Jr, Higginbottom F, Solnit GA. Multicenter retrospective analysis of the ITI implant system used for single-tooth replacements: results of loading for 2 or more years. Int J Oral Maxillofac Implants. 1999 JulAug;14(4):516-20.

Lin CL, Chang SH, Chang WJ, Kuo YC. Factorial analysis of variables influencing mechanical characteristics of a single tooth implant placed in the maxilla using finite element analysis and the statistics-based Taguchi method. Eur J Oral Sci. 2007 Out;115(5):408-16.

Luo J, Hu XL, Lin Y, Qiu LX, Di P, Li JH. Influence of the placing depth of implants with platform switching on the marginal bone level in the posterior mandible: a clinical study. Beijing Da Xue Xue Bao. 2012 Feb 18;44(1):65-9.

Luongo R, Traini T, Guidone PC, Bianco G, Cocchetto R, Celletti R. Hard and soft tissue responses to the platform-switching technique. Int $\mathrm{J}$ Periodontics Restorative Dent. 2008 Dec;28(6):551-7. 
Maeda Y, Satoh T, Sogo M. In Vitro differences of stress concentrations for internal and external hex implant-abutment connections: a short communication. J Oral Rehabil. 2006 Jan;33(1):75-8.

Mahler DB, Peyton FA. Photoelasticity as a research technique for analyzing stresses in dental structures. J Dent Res. 1955 Dec;34(6):831-8.

Maia LG, de Moraes Maia ML, da Costa Monini A, Vianna AP, Gandini LG Jr. Photoelastic analysis of forces generated by T-loop springs made with stainless steel or titanium-molybdenum alloy. Am J Orthod Dentofacial Orthop. 2011 Sep;140(3):e123-8.

Mangano C, Mangano F, Piattelli A, Lezzi G, Mangano A, La Colla L. Prospective clinical evaluation of 1920 Morse taper connection implants: results after 4 years of functional loading. Clin Oral Implants Res. 2009 Mar;20(3):254-61.

Mangano C, Mangano F, Piattelli A, Lezzi G, Mangano A, La Colla L. Prospective clinical evaluation of 307 single-tooth morse taper-connection implants: a multicenter study. Int J Oral Maxillofac Implants. 2010 Mar-Apr;25(2):394-400.

Markarian RA, Ueda C, Sendyk CL, Laganá DC, Souza RM. Stress distribution after installation of fixed frameworks with marginal gaps over angled and parallel implants: a photoelastic analysis. J Prosthodont. 2007 Mar-Apr;16(2):117-22.

Merz BR, Hunenbart S, Belser UC. Mechanics of the implant-abutment connection: an 8-degree taper compared to a butt joint connection. Int J Oral Maxillofac Implants. 2000 Jul-Aug;15(4):519-26.

Misch CE, Bidez MW, Sharawy M. A bioengineered implant for a predetermined bone cellular response to loading forces. A literature review and case reports. J Periodontol. 2001 Sep;72(9):1276-1286.

Misch CE, Strong T. Scientific rationale for dental implant design. In: MISCH, CE. Contemporary Implant Dentistry. St. Louis: Elsevier, 1999; p.200-229.

Morgan KM, Chapman RJ. Retrospective analysis of an implant system. Compend Contin Educ Dent. 1999 Jul;20(7):609-14,616-23.

Montarou CC, Gaylord TK. Two-wave-plate compensator method for single-point retardation measurements. Appl Opt. 2004 Dec 20;43(36):6580-95.

Morris HF, Ochi S, Crum P, Orenstein IH, Winkler S. AICRG, Part I: A 6-year multicentered, multidisciplinary clinical study of a new and innovative implant design. J Oral Implantol. 2004;30(3):125-33.

Naert IE, Duyck JA, Hosny MM, Van Steenberghe D. Freestanding and tooth-implant connected prostheses in the treatment of partially edentulous patients. Part I: an up to 15-years clinical evaluation. Clin Oral Implants Res. 2001 Jun;12(3):237-44. 
Nentwig GH. The Ankylos implant system: concept and clinical application. J Oral Implantol. 2004;30(3):171-7.

Norton MR. Assessment of cold welding properties of the internal conical interface of two commercially available implant systems. J Prosthet Dent. 1999 Feb;81(2):15966.

Norton MR. An in vitro evaluation of the strength of an internal conical interface compared to a butt joint interface in implant design. Clin Oral Implants Res. 1997 Aug;8(4):290-8.

Norton MR. In vitro evaluation of the strength of the conical implant to abutment joint in two commercially available implant systems. J Prosthet Dent. 2000 May;83(5):56771.

Novaes Jr AB, de Oliveira RR, Muglia VA, Papalexiou V, Taba M. The effects of interimplant distances on papilla formation and crestal resorption in implants with a morse cone connection and a platform switch: a histomorphometric study in dogs. J Periodontol. 2006 Nov;77(11):1839-1849.

Novaes Jr AB, Barros RR, Muglia VA, Borges GJ. Influence of interimplant distances and placement depth on papilla formation and crestal resorption: a clinical and radiographic study in dogs. J Oral Implantol. 2009;35(1):18-27.

Oh TJ, Yoon J, Misch CE, Wang HL. The causes of early implant bone loss: myth or science? J Periodontol. 2002 Mar;73(3):322-33.

Park JK, Choi JU, Jeon YC, Choi KS, Jeong CM. Effects of abutment screw coating on implant preload. J Prosthodont. 2010 Aug;19(6):458-64.

Pellizzer EP, Carli RI, Falcón-Antenucci RM, Verri FR, Goiato MC, Villa LM. Photoelastic analysis of stress distribution with different implant systems. J Oral Implantol. 2014 Apr;40(2):117-22.

Perriard J, Wiskott WA, Mellal A, Scherrer SS, Botsis J, Belser UC. Fatigue resistance of ITI implant-abutment connectors - a comparison of the standard cone white a novel internally keyed design. Clin Oral Implants Res. 2002 Oct;13(5):542-9.

Persson LG, Lekholm U, Leonhardt A, Dahlén G, Lindhe J. Bacterial colonization on internal surfaces of branemark system implant components. Clin Oral Implants Res. 1996 Jun;7(2):90-5.

Pessoa RS, Muraru L, Júnior EM, Vaz LG, Sloten JV, Duyck J, Jaecques SV. Influence of implant connection type on the biomechanical environment of immediately placed implants-CT-based nonlinear, three-dimensional finite element analysis. Clin Implant Dent Relat Res. 2010 Sep;12(3):219-34.

Piattelli A, Scarano A, Paolantonio M, Assenza B, Leghissa GC, Di Bonaventura G, Catamo G, Piccolomini R. Fluids and microbial penetration in the internal part of 
cement-retained versus screw-retained implant-abutment connections. J Periodontol. 2001 Sep;72(9):1146-1150.

Piermatti J, Yousef H, Luke A, Mahevich R, Weiner S. An in vitro analysis of implant screw torque loss with external hex and internal connection implant systems. Implant Dent. 2006 Dec;15(4):427-35.

Pintinha M, Camarini ET, Sábio S, Pereira JR. Effect of mechanical loading on the removal torque of different types of tapered connection abutments for dental implants. J Prosthet Dent. 2013 Nov;110(5):383-8.

Pjetursson BE, Bragger U, Lang NP, Zwahlen M. Comparison of survival and complication rates of tooth-supported fixed dental prostheses (fdps) and implantsupported fdps and single crowns (scs). Clin Oral Implants Res. 2007 Jun;18 Suppl 3:97-113.

Pontes AE, Ribeiro FS, Lezzi G, Piattelli A, Cirelli JA, Marcantonio E Jr. Biologic width changes around loaded implants inserted in different levels in relation to crestal bone: histometric evaluation in canine mandible. Clin Oral Implants Res. 2008 May;19(5):483-90.

Prendergast PJ, Huiskes R. Microdamage and osteocyte-lacuna strain in bone: amicrostructural finite element analysis. J Biomech Eng. 1996 May;118(2):240-6.

Quaresma SE, Cury PR, Sendyk WR, Sendyk C. A finite elemento analysis of two different dental implants: Stress distribution in the prosthesis, abutment, implant and supporting bone. J Oral Implantol. 2008;34(1):1-6.

Quirynen M, Van Steenberghe D. Bacterial colonization of the internal part of twostage implants. An in vivo study. Clin Oral Implants Res. 1993 Sep;4(3):158-61.

Quirynen M, Bollen CM, Eyssen H, Van Steenberghe D. Microbial penetration along the implant components of the Branemark system: an in vitro study. Clin Oral Implants Res. 1994 Dec;5(4):239-44.

Rangert B, Gunne J, Sullivan DY. Mechanical aspects of a Branemark implant connected to a natural tooth: an in vitro study. Int $\mathrm{J}$ Oral Maxillofac Implants. 1991;6(2):177-86.

Rangert B. Mechanical and biomechanical guidelines for the use of Branemark System-general principles. Aust Prosthodont J. 1993;7 Supl:39-44.

Rangert B, Krogh PH, Langer B, Van Roekel N. Bending overload and implant fracture: a retrospective clinical analysis. Int J Oral Maxillofac Implants. 1995 MayJun;10(3):326-34.

Ricomini Filho AP, Fernandes FS, Straioto FG, da Silva WJ, Del Bel Cury AA. Preload loss and bacterial penetration on different implant-abutment connection systems. Braz Dent J. 2010;21(2):123-9. 
Rigsby DF, Bidez MW, Misch CE. Bone Response to Mechanical Loads. In: Misch CE, editor. Contemporary implant dentistry. 2nd ed. St. Louis: Mosby; 1998; p.31728.

Rodriguez AM, Rosenstiel SF. Esthetic considerations related to bone and soft tissue maintenance and development around dental implants: Report of the Committee on Research in Fixed Prosthodontics of the American Academy of Fixed Prosthodontics. J Prosthet Dent. 2012 Oct;108(4):259-67.

Rodríguez-Ciurana X, Vela-Nebot X, Segalà-Torres M, Calvo-Guirado JL, Cambra $J$, Méndez-Blanco V, Tarnow DP. The effect of interimplant distance on the height of the interimplant bone crest when using platform-switched implants. Int J Periodontics Restorative Dent. 2009 Apr;29(2):141-51.

Romanos GE, Traini T, Johansson CB, Piattelli A. Biologic width and morphologic characteristics of soft tissues around immediately loaded implants: studies performed on human autopsy specimens. J Periodontol. 2010 Jan;81(1):70-8.

Roos-Jansåker AM, Lindahl C, Renvert H, Renvert S. Nine to fourteen-year follow-up of implant treatment. Part I: implant loss and associations to various factors. J Clin Periodontol. 2006 Apr;33(4):283-9.

Sailer I, Zembic A, Jung RE, Hammerle $\mathrm{CH}$, Mattiola A. Single tooth implant reconstructions: esthetic factors influencing the decision between titanium and zirconia abutments in anterior regions. Eur J Esthet Dent. 2007 Autumn;2(3):296310.

Schmitt CM, Nogueira-Filho G, Tenenbaum HC, Lai JY, Brito C, Döring H, Nonhoff J.Performance of conical abutment (Morse Taper) connection implants: A systematic review. J Biomed Mater Res A. 2014 Feb;102(2):552-74.

Seetoh YL, Tan KB, Chua EK, Quek HC, Nicholls Jl. Load fatigue performance of conical implant-abutment connections. Int J Oral Maxillofac Implants. 2011 JulAgo;26(4):797-806.

Stein AE, McGlmphy EA, Johnston WM, Larsen PE. Effects of implant design and surface roughness on crestal bone and soft tissue levels in the esthetic zone. Int $J$ Oral Maxillofac Implants. 2009 Set-Out;24(5):910-9.

Sutter F, Weber HP, Sorensen J, Belser U. The new restorative concept of the ITI dental implant system. Design and engineering. Int $\mathrm{J}$ Periodontics Restorative Dent. 1993;13:409-431.

Tabata LF, Assunção WG, Adelino Ricardo Barão V, de Souza EA, Gomes EA, Delben JA. Implant platform switching: biomechanical approach using twodimensional finite element analysis. J Craniofac Surg. 2010 Jan;21(1):182-7.

Tenenbaum H, Schaaf JF, Cuisinier FJ. Histological analysis of the Ankylos periimplant soft tissues in a dog model. Implant Dent. 2003;12(3):259-65. 
Tesmer M, Carteira S, Koutouzis T, Lundgren T. Bacterial colonization of the dental implant fixture-abutment interface: an in vitro study. $J$ Periodontol. 2009 Dec;80(12):1991-7.

Tiossi R. Efeito do uso de próteses múltiplas implantossuportadas, unidas e isoladas, nas tensões geradas em áreas posteriores da mandibula [tese]. Ribeirão Preto: Faculdade de Odontologia de Ribeirão Preto, Universidade de São Paulo; 2010.

Todescan FF, Pustiglioni FE, Imbronito AV, Albrektsson T, Gioso M. Influence of the microgap in the peri-implant hard and soft tissues: a histomorphometric study in dogs. Int J Oral Maxillofac Implants. 2002 Jul-Aug;17(4):467-72.

Torres, EM. Análise fotoelástica das tensões geradas por diferentes planejamentos de próteses parciais fixas parafusadas sobre implantes cone morse [tese]. Ribeirão Preto: Faculdade de Odontologia de Ribeirão Preto, Universidade de São Paulo; 2008.

Tran BL, Chen ST, Caiafa A, Davies HM, Darby IB. Transmucosal healing around peri-implant defects: crestal and subcrestal implant placement in dogs. Clin Oral Implants Res. 2010 Ago; 21 (8): 794-803.

Vela-Nebot X, Rodríguez-Ciurana X, Rodado-Alonso C, Segala-M Torres. Benefits of an implant platform modification technique to reduce crestal bone resorption. Implant Dent. 2006 Sep;15(3):313-20.

Walton JN, MacEntee MI. A prospective study on the maintenance of implant prosthereses in private practice. Int J Prosthodont. 1997 Set-Out;10(5):453-8.

Wagenberg B, Froum SJ. Prospective study of 94 platform switched implants observed from 1992 to 2006. Int J Periodontics Restorative Dent. 2010 Feb;30(1):917.

Weigl P. New prosthetic restorative features of Ankylos implant system. J Oral Implantol. 2004;30(3):178-88.

Welander M, Abrahamsson I, Berglundh T. Subcrestal placement of two-part implants. Clin Oral Implants Res. 2009 Mar;20(3):226-31.

Weng D, Nagata MJ, Sino M, Bosco AF, de Melo LG, Richter EJ. Influence of microgap location and configuration on the periimplant bone morphology in submerged implants. An experimental study in dogs. Clin Oral Implants Res. 2008 Nov;19(11):1141-7.

Wolff, J. (1892) The Laws of Bone Remodeling.Berlin: Springer.

Zak B. Photoelastiche analyse in der orthodontischen mechanik. Z Stomatol 1935;33:22-37. 